Economic Impacts on the United States of Siting Decisions for the International Thermonuclear Experimental Reactor

Decision and Information Sciences Division

Argonne National Laboratory

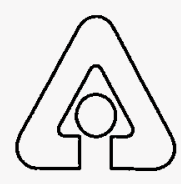

Operated by The University of Chicago. under Contract W-31-109-Eng-38, for the

United States Department of Energy 


\section{Argonne National Laboratory}

Argonne National Laboratory, with facilities in the states of Illinois and Idaho, is owned by the United States Government, and operated by the University of Chicago under the provisions of a contract with the Department of Energy.

This technical report is a product of Argonne's Decision and Information Sciences Division. For information on the division's scientific and engineering activities, contact:

Director, Decision and Information Sciences Division

Argonne National Laboratory

Argonne, Illinois 60439-4815

Telephone (630) 252-5464

Home page: http://www.dis.anl.gov/

Publishing support services were provided by Argonne's Information and Publishing Division (for more information, see IPD's home page: http://www.ipd.anl.gov/).

\section{Disclaimer}

This report was prepared as an account of work sponsored by an agency of the United States Government. Neither the United States Government nor any agency thereof, nor any of their employees, makes any warranty, express or implied, or assumes any legal liability or responsibility for the accuracy, completeness, or usefulness of any information, apparatus, product, or process disclosed, or represents that its use would not infringe privately owned rights. Reference herein to any specific commercial product, process, or service by trade name, trademark, manufacturer, or otherwise, does not necessarily constitute or imply its endorsement, recommendation, or favoring by the United States Government or any agency thereof. The views and opinions of authors expressed herein do not necessarily state or reflect those of the United States Government or any agency thereof.

Reproduced directly from the best available copy.

Available to DOE and DOE contractors from the Office of Scientific and Technical Information, P.O. Box 62, Oak Ridge, TN 37831; prices available from (423) 576-8401.

Available to the public from the National Technical Information Service, U.S. Department of Commerce, 5285 Port Royal Road, Springfield, VA 22161. 


\section{Economic Impacts on the United States of Siting Decisions for the International Thermonuclear Experimental Reactor}

by J.P. Peerenboom, M.E. Hanson, J.R. Huddleston, T.D. Wolsko, S.H. Pollock, D.S. Meade, T. Allison, D.A. Hanson, A.Z. Rose, A.M. Schaal, and R. Monaco

Decision and Information Sciences Division,

Argonne National Laboratory, 9700 South Cass Avenue, Argonne, Illinois 60439

August 1996

Work sponsored by United States Department of Energy, Office of Fusion Energy 
This report is printed on recycled paper. 


\section{DISCLAIMER}

Portions of this document may be illegible in electronic image products. Images are produced from the best available original document. 


\section{DISCLAIMER}

This report was prepared as an account of work sponsored by an agency of the United States Government. Neither the United States Government nor any agency thereof, nor any of their employees, makes any warranty, express or implied, or assumes any legal liability or responsibility for the accuracy, completeness, or usefulness of any information, apparatus, product, or process disclosed, or represents that its use would not infringe privately owned rights. Reference herein to any specific commercial product, process, or service by trade name, trademark, manufacturer, or otherwise does not necessarily constitute or imply its endorsement, recommendation, or favoring by the United States Government or any agency thereof. The views and opinions of authors expressed herein do not necessarily state or reflect those of the United States Government or any agency thereof. 


\section{CONTENTS}

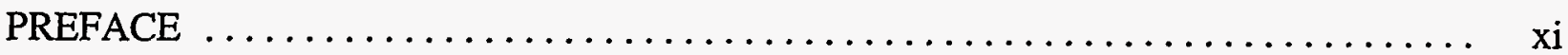

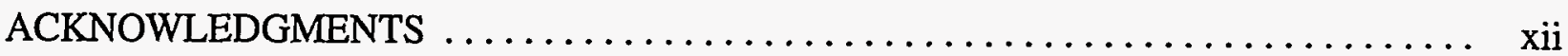

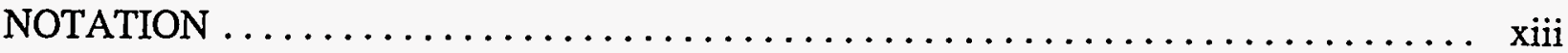

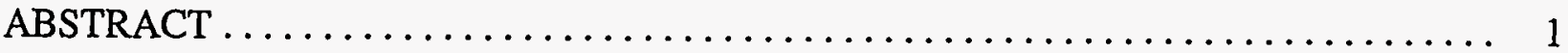

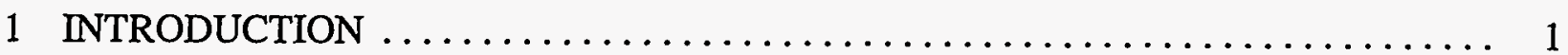

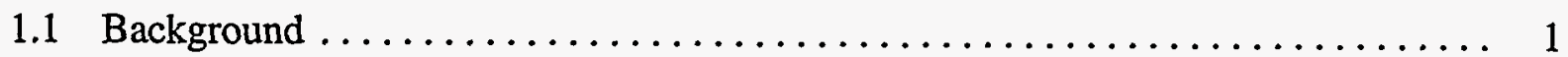

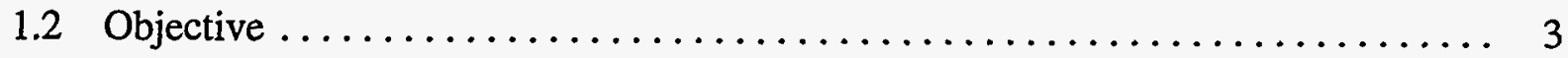

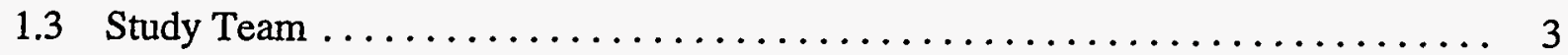

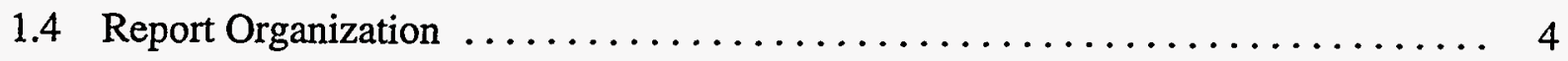

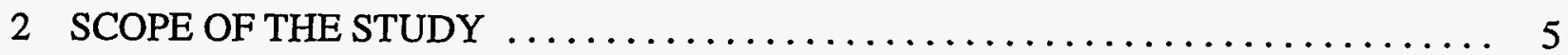

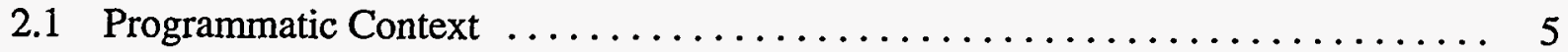

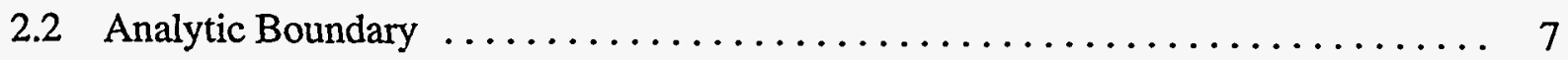

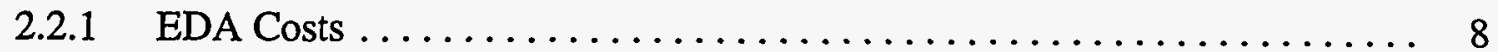

2.2.2 Regulatory/Licensing Costs $\ldots \ldots \ldots \ldots \ldots \ldots \ldots \ldots \ldots \ldots \ldots$

2.2.3 Site Selection and Preparation Costs $\ldots \ldots \ldots \ldots \ldots \ldots \ldots \ldots \ldots, 8$

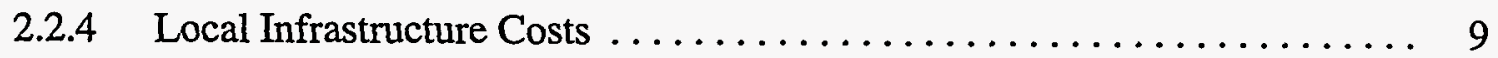

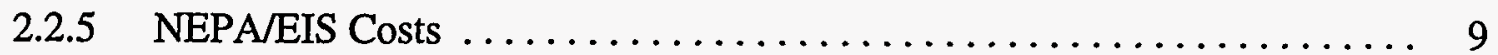

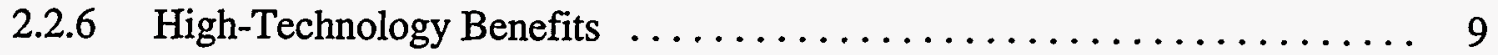

2.2.7 Spin-off Benefits . . . . . . . . . . . . . . . . . . . . . . . 9

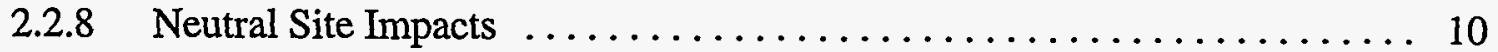

2.2.9 Balance-of-Trade Impacts with ITER Parties $\ldots \ldots \ldots \ldots \ldots \ldots \ldots \ldots$

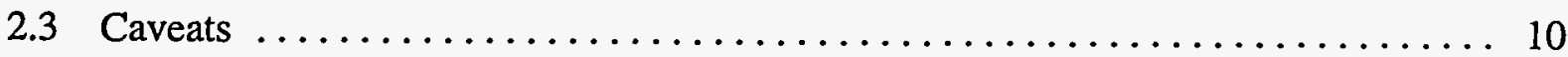

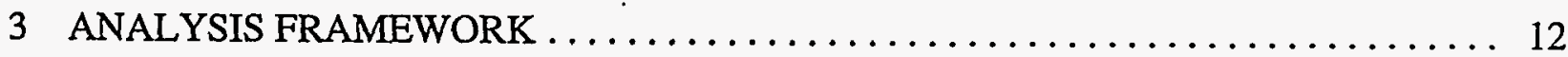

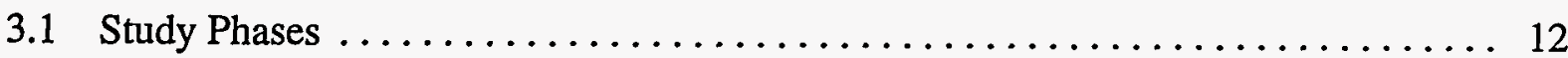

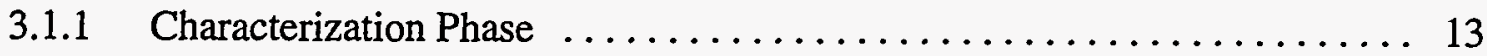

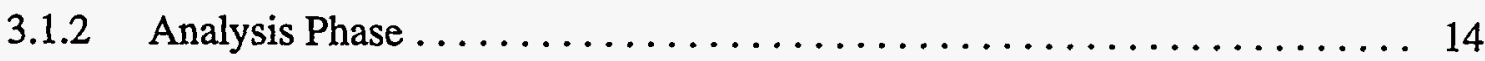

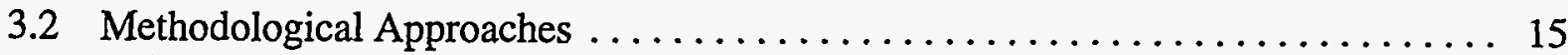

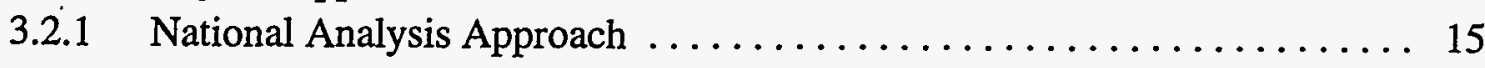

3.2.2 Local/Regional Analysis Approach ..................... 17 


\section{CONTENTS (Cont.)}

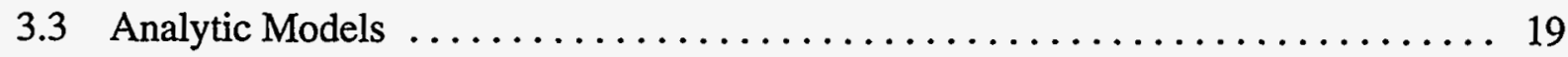

3.3.1 National Economic Models ......................... 20

3.3.2 Local/Regional Economic Model ...................... 21

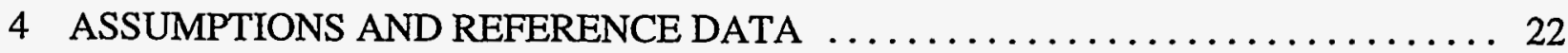

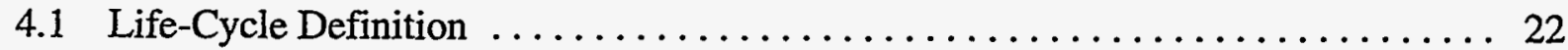

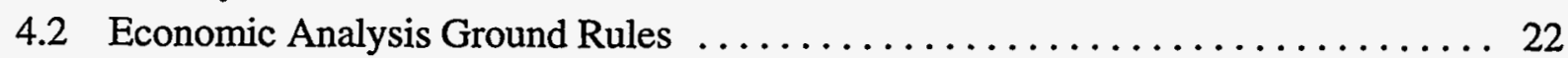

4.3 Reference Cost Data . . . . . . . . . . . . . . . . . . . . . . 23

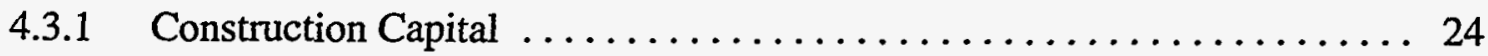

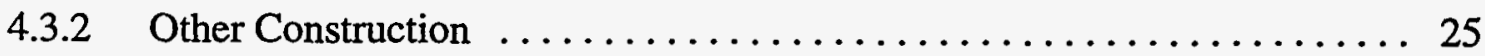

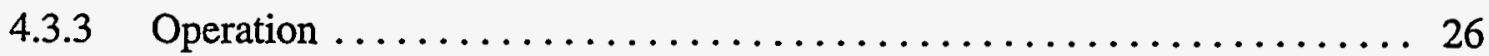

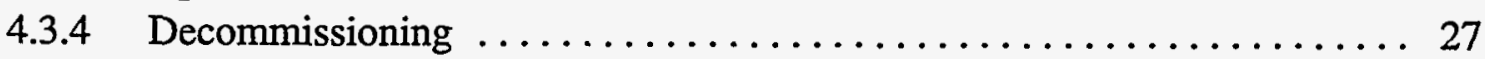

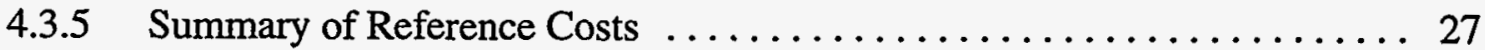

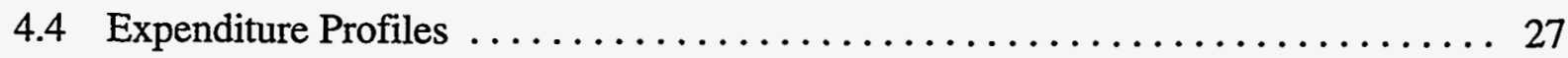

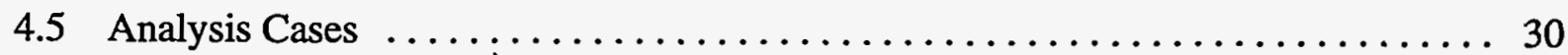

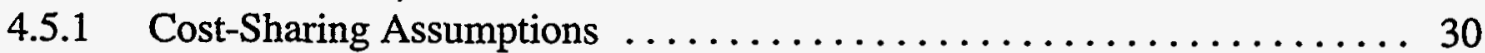

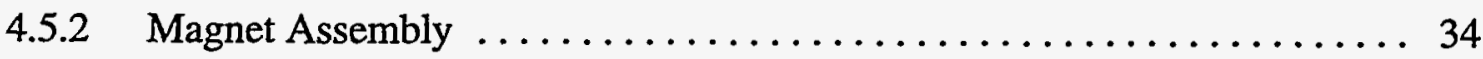

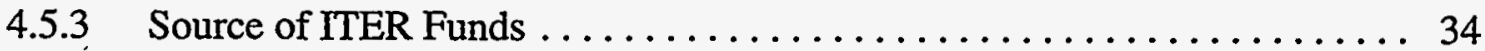

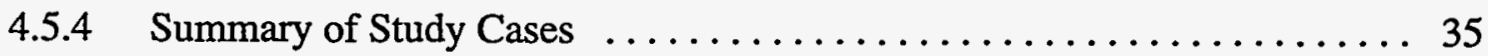

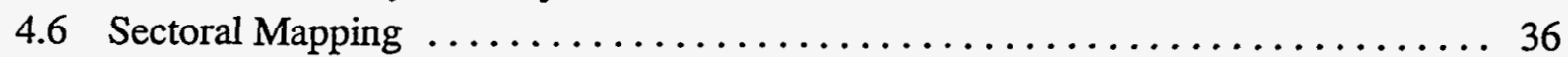

5 ESTIMATED NATIONAL AND LOCAL/REGIONAL ECONOMIC IMPACTS . . . . 40

5.1 National Economic Analysis . . . . . . . . . . . . . . . . . . . . 40

5.1 .1 Reference Case ................................. 40

$5.1 .2 \quad$ S\&T Budget Realignment Case $\ldots \ldots \ldots \ldots \ldots \ldots \ldots \ldots \ldots \ldots 47$

5.1.3 Supplemental Budget Case ......................... 47

5.1 .4 Increased Non-Host Participation Case . . . . . . . . . . . . . . . . 49

5.1.5 Magnet Option Case ............................. 49

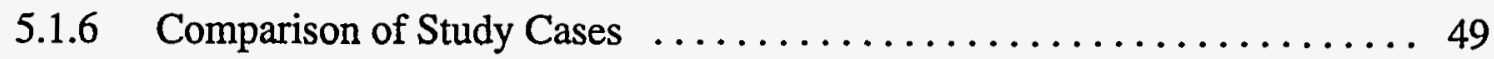

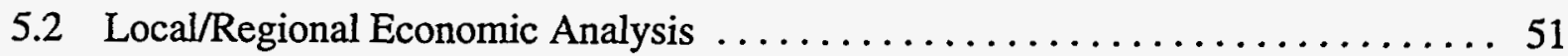

$5.2 .1 \quad$ Reference Case ................................. 57

5.2.2 Increased Non-Host Participation Case . . . . . . . . . . . . . . . 60

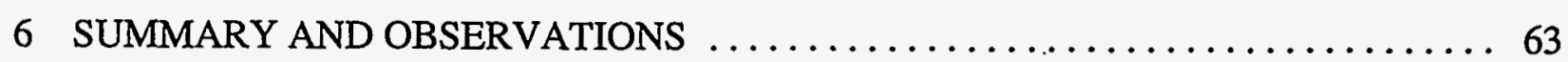

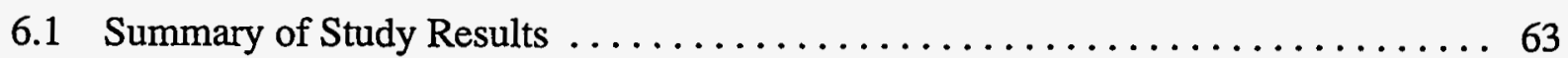

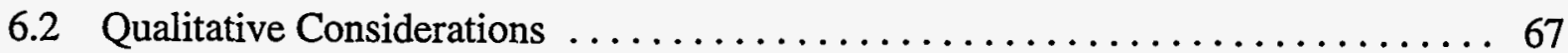




\section{CONTENTS (Cont.)}

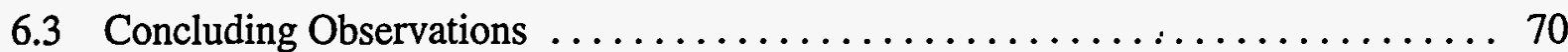

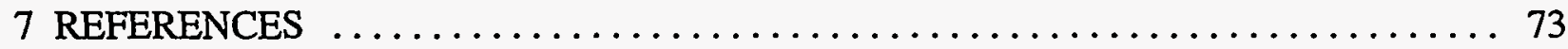

APPENDIX A: The International Thermonuclear Experimental

Reactor Program: Technology and Organization $\ldots \ldots \ldots \ldots \ldots \ldots .75$

APPENDIX B: $\quad$ LIFT Model Description $\ldots \ldots \ldots \ldots \ldots \ldots \ldots \ldots \ldots \ldots \ldots \ldots$

APPENDIX C: AMIGA Model Description $\ldots \ldots \ldots \ldots \ldots \ldots \ldots \ldots \ldots \ldots . \ldots . \ldots . \ldots$

APPENDIX D: IMPLAN Model Description $\ldots \ldots \ldots \ldots \ldots \ldots \ldots \ldots \ldots \ldots \ldots$

APPENDIX E: Life-Cycle Cost Characterization Data ................... 99

FIGURES

1 ITER in the Context of the U.S. Fusion Energy Programs $\ldots \ldots \ldots \ldots \ldots \ldots \ldots$

2 Scope of the ITER Economic Study $\ldots \ldots \ldots \ldots \ldots \ldots \ldots \ldots \ldots \ldots \ldots \ldots \ldots$

$3 \quad$ ITER Economic Study Boundary $\ldots \ldots \ldots \ldots \ldots \ldots \ldots \ldots \ldots \ldots \ldots \ldots \ldots \ldots \ldots$

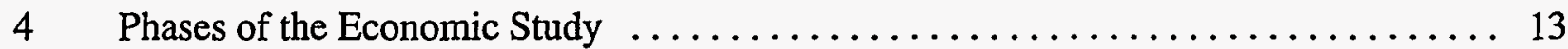

5 Conceptual Framework for National and Local/Regional ITER

Economic Analyses .................................. 14

6 Conceptual Framework for National Analysis $\ldots \ldots \ldots \ldots \ldots \ldots \ldots \ldots \ldots$

$7 \quad$ Conceptual Framework for Local/Regional Analysis $\ldots \ldots \ldots \ldots \ldots \ldots \ldots \ldots$

8 Distribution of ITER Construction Capital Costs and Tokamak Magnet Costs . . . . . 29

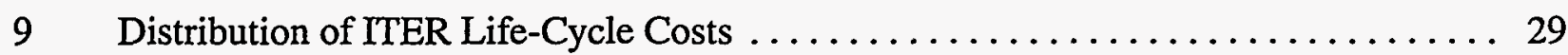

10 Distribution of Host/Non-Host Costs: Reference Case $\ldots \ldots \ldots \ldots \ldots \ldots \ldots . \ldots 2$ 


\section{FIGURES (Cont.)}

11 Summary of Host/Non-Host Costs by Category: Reference Case . . . . . . . . . . 33

12 Cumulative Annual Host and Non-Host Costs: Reference Case . . . . . . . . . 33

13 ITER Expenditures Relative to Total Federal Government Expenditures:

Reference Case $\ldots \ldots \ldots \ldots \ldots \ldots \ldots \ldots \ldots \ldots \ldots \ldots \ldots \ldots \ldots \ldots \ldots$

14 Comparison of U.S. Host and Non-Host Expenditures: Reference Case . . . . . . . . 44

15 Annual ITER Sectoral Employment Impacts: Reference Case . . . . . . . . . 45

16 Annual ITER Sectoral Employment Impacts: Supplemental Budget Case . . . . . . 48

17 Comparison of Changes in GDP for ITER Study Cases $\ldots \ldots \ldots \ldots \ldots \ldots \ldots$

18 Comparison of Changes in Employment for ITER Study Cases $\ldots \ldots \ldots \ldots \ldots$

19 Direct Spending in the U.S. and Local Area: Reference Case . . . . . . . . . . 56

A.1 A Computer-Generated Model of the ITER Device $\ldots \ldots \ldots \ldots \ldots \ldots \ldots \ldots$

C.1 Economic Effects Represented by the AMIGA Model . . . . . . . . . . . . 92

\section{TABLES}

1 ITER Construction Capital Cost Estimates $\ldots \ldots \ldots \ldots \ldots \ldots \ldots \ldots \ldots$

2 Summary of ITER Life-Cycle Reference Costs $\ldots \ldots \ldots \ldots \ldots \ldots \ldots \ldots$

3 Expenditure Profiles for ITER Construction $\ldots \ldots \ldots \ldots \ldots \ldots \ldots \ldots \ldots$

4 Host/Non-Host Cost Sharing Arrangements: Reference Case . . . . . . . . . . 32

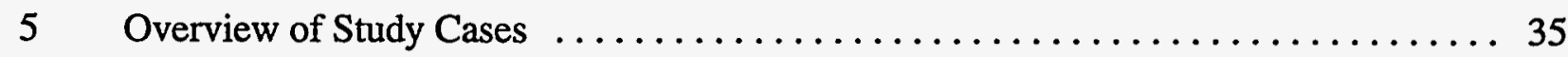

6 Sectoral Mapping for ITER Toroidal Field Magnet System . . . . . . . . . . 37 


\section{TABLES (Cont.)}

$7 \quad$ Mapping of ITER Expenditures to Economic Sectors $\ldots \ldots \ldots \ldots \ldots \ldots \ldots$

8 Life-Cycle Direct Spending in the U.S. by Sector: Reference Case $\ldots \ldots \ldots \ldots \ldots 4$

$9 \quad$ U.S. Host Trade Balance Impacts: Reference Case $\ldots \ldots \ldots \ldots \ldots \ldots \ldots$

10 Sector Multipliers and Local Purchase Coefficients $\ldots \ldots \ldots \ldots \ldots \ldots \ldots \ldots$

11 Life-Cycle Direct Spending in Local Area by Sector: Reference Case .......... 54

12 Life-Cycle Direct Spending in Local Area by Sector: Increased Non-Host Participation Case $\ldots \ldots \ldots \ldots \ldots \ldots \ldots \ldots \ldots \ldots \ldots \ldots \ldots$

13 Local Area Primary Jobs Created: Reference Case $\ldots \ldots \ldots \ldots \ldots \ldots \ldots$

14 Local Area Output, Personal Income, and Employment Benefits: Reference Case .............................. 59

15 Local Area Primary Jobs Created: Increased Non-Host

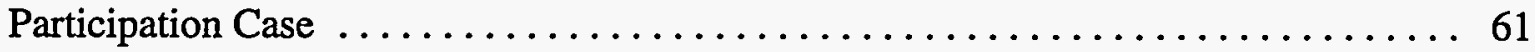

16 Local Area Output, Personal Income, and Employment Benefits:

Increased Non-Host Participation Case $\ldots \ldots \ldots \ldots \ldots \ldots \ldots \ldots \ldots \ldots . \ldots 1$

E.1 Host/Non-Host Funding and Spending Assumptions:

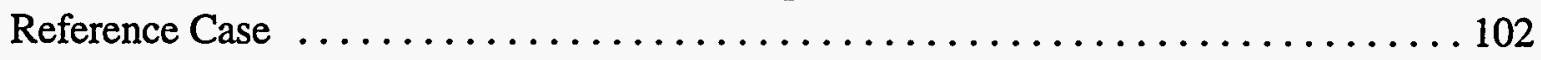

E.2 Summary of Host and Non-Host Life-Cycle Costs: Reference Case . . . . . . . . . 103

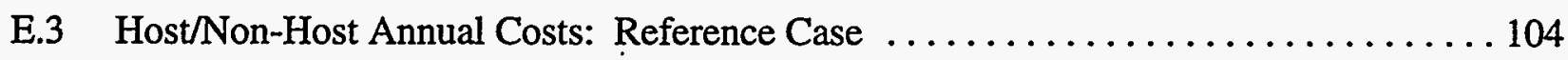

E.4 Labor Costs for Host Site Magnet Assembly: Reference Case $\ldots \ldots \ldots \ldots \ldots$

E.5 Non-Host Spending Assumptions for Labor at Host Site:

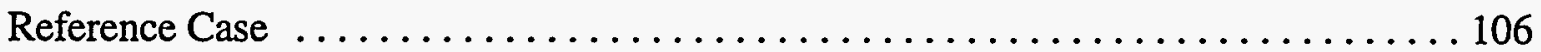

E.6 Host Spending Assumptions for Labor at Host Site: Reference Case . . . . . . . 107

vii 


\section{TABLES (Cont.)}

E.7 Non-Host Labor, Material, and Equipment Cost Breakdown

for Operation Categories: Reference Case

E.8 Host Labor, Material, and Equipment Cost Breakdown

for Operation Categories: Reference Case .......................... 109

E.9 Annual Labor Costs at Host Site: Reference Case . . . . . . . . . . . . . . . 110

E.10 Host Cost Breakdown by Cost Category: Reference Case $\ldots \ldots \ldots \ldots \ldots \ldots \ldots 11$

E.11 U.S. Host Versus U.S. Non-Host Cost Comparison:

Reference Case ......................................... 112

E.12 Labor Costs for Host Site Magnet Assembly: Magnet Option Case ............ 113

E.13 Host/Non-Host Funding and Spending Assumptions:

Magnet Option Case

E.14 Summary of Host and Non-Host Life-Cycle Costs:

Magnet Option Case

E.15 Host/Non-Host Annual Costs: Magnet Option Case .................... 116

E.16 Non-Host Spending Assumptions for Labor at Host Site:

Magnet Option Case

E.17 Host Spending Assumptions for Labor at Host Site:

Magnet Option Case

E.18 Annual Labor Costs at Host Site: Magnet Option Case ................... 119

E.19 Host Cost Breakdown by Cost Category: Magnet Option Case $\ldots \ldots \ldots \ldots \ldots . \ldots 120$

E.20 U.S. Host Versus U.S. Non-Host Cost Comparison:

Magnet Option Case

E.21 Host/Non-Host Funding and Spending Assumptions:

Increased Non-Host Participation Case . . 


\section{TABLES (Cont.)}

E.22 Summary of Host and Non-Host Life-Cycle Costs:

Increased Non-Host Participation Case . . . . . . . . . . . . . . . . . . 123

E.23 Host/Non-Host Annual Costs: Increased Non-Host

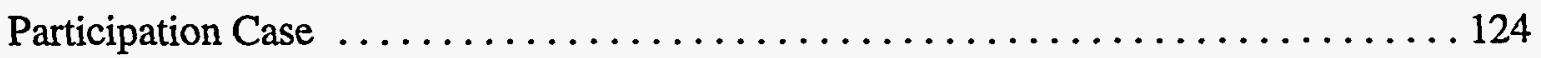

E.24 Non-Host Spending Assumptions for Labor at Host Site:

Increased Non-Host Participation Case . . . . . . . . . . . . . . . . . . 125

E.25 Host Spending Assumptions for Labor at Host Site:

Increased Non-Host Participation Case . . . . . . . . . . . . . . . . 126

E.26 Annual Labor Costs at Host Site: Increased Non-Host

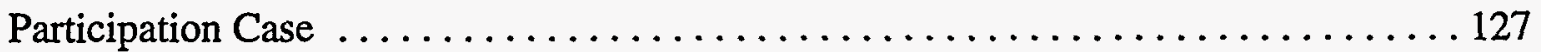

E.27 Host Cost Breakdown by Cost Category: Increased Non-Host

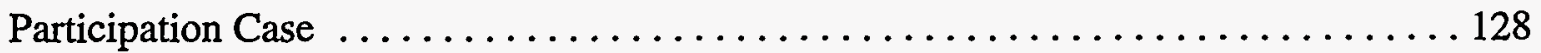

E.28 U.S. Host Versus U.S. Non-Host Cost Comparison:

Increased Non-Host Participation Case . . . . . . . . . . . . . . . . . 129 


\section{DISCLAIMER}

The work described in this report was completed prior to the substantial restructuring of the fusion program's goals, objectives, and budget for fiscal year 1996 and beyond. Because of this restructuring, the U.S. government is no longer considering the possibility of hosting the International Thermonuclear Experimental Reactor (ITER). Nevertheless, continuing participation in the ITER Engineering Design Activities and the potential limited financial participation in future ITER construction and operation remain important parts of the new U.S. fusion energy sciences program. While some of the planning assumptions are no longer valid, this early 1995 strategy is being published with the hope that the methodology may be valuable to any further economic studies. 


\section{PREFACE}

This study was conducted by a multidisciplinary team of economists and engineers from academia, the private sector, and the U.S. Department of Energy (DOE) national laboratory system. The study was managed by Argonne National Laboratory and supported by the DOE, Office of Fusion Energy. The team consisted of the following members:

\section{STUDY DIRECTORS}

\author{
Dr. Thomas D. Wolsko \\ Deputy Division Director \\ Decision and Information Sciences Division \\ Argonne National Laboratory
}

Dr. James P. Peerenboom

Group Leader, Systems Science

Decision and Information Sciences Division

Argonne National Laboratory

\section{NATIONAL ANALYSIS WORKING GROUP}

Dr. Gale A. Boyd

Economist

Argonne National Laboratory

Dr. Mark Hanson ${ }^{1,2}$

Director of Technical Studies

Resource Management Associates

Dr. Douglas S. Meade

Economist

INFORUM, University of Maryland

Dr. Adam Z. Rose

Professor of Mineral Economics

Pennsylvania State University
Dr. Donald A. Hanson

Economist/Manager of Energy Policy Section

Argonne National Laboratory

Ms. Margaret B. McCarthy

Economist

INFORUM, University of Maryland

Dr. Ralph M. Monaco

Economist

INFORUM, University of Maryland

Mr. A. Michael Schaal ${ }^{3}$

Department of Mineral Economics

Pennsylvania State University

\section{LOCAL/REGIONAL ANALYSIS WORKING GROUP}

\begin{abstract}
Mr. Timothy Allison
Economic Geographer

Argonne National Laboratory .

Dr. F. (Fredrick) Larry Leistritz

Professor of Agricultural Economics

North Dakota State University
\end{abstract}

\author{
Dr. Jack R. Huddleston ${ }^{1}$ \\ Professor of Urban and Regional Planning \\ University of Wisconsin-Madison
}

Dr. Stephen H. Pollock, Senior Manager ${ }^{4}$

Barents Group, LLC of KPMG

Peat Marwick, LLP

1 Working Group leader.

2 Dr. Hanson is currently the Executive Director of the Energy Center of Wisconsin.

$3 \mathrm{Mr}$. Schaal is currently with Energy Ventures Analysis, Inc.

4 Dr. Pollock is currently with the Economic Consulting Services of KPMG Peat Marwick, LLP. 


\section{ACKNOWLEDGMENTS}

The authors gratefully acknowledge the U.S. Department of Energy, Office of Fusion Energy, for its support of this study. We particularly appreciate the guidance and technical assistance of the study sponsors, Ira Adler, Thomas James, Warren Marton, Gene Nardella, and Michael Roberts. We also thank members of the International Thermonuclear Experimental Reactor (ITER) Steering Committee - the United States, U.S. ITER Industry Council, and U.S. ITER Home Team for their comments on the study and their insights into the complex issues surrounding ITER and the development of magnetic fusion as an energy source. Finally, we thank Argonne National Laboratory colleagues William Buehring and Ronald Whitfield for technical assistance, Jeffrey Camp for analysis support, Glenda Ramsey for administrative assistance, Margaret Clemmons and Betty Waterman for editorial assistance, the Document Processing Center for word processing support, and Marie Reed and Sandra Schreader for secretarial support. 


\section{NOTATION}

\begin{tabular}{|c|c|}
\hline AMIGA & Argonne Multisector Industrial Growth Assessment (Model) \\
\hline ANL & Argonne National Laboratory \\
\hline BEA & Bureau of Economic Analysis \\
\hline CDA & Conceptual Design Activities \\
\hline DOE & U.S. Department of Energy \\
\hline EDA & Engineering Design Activities \\
\hline EIS & environmental impact statement \\
\hline FPA & Fusion Power Associates \\
\hline GDP & gross domestic product \\
\hline IAEA & International Atomic Energy Agency \\
\hline IMPLAN & Impact Analysis for Planning \\
\hline INFORUM & Interindustry Forecasting Project of the University of Maryland \\
\hline ISCUS & ITER Steering Committee - U.S. \\
\hline ITER & International Thermonuclear Experimental Reactor \\
\hline LIFT & Long-Term Interindustry Forecasting Tool \\
\hline LPC & local purchase coefficient \\
\hline NEC & not elsewhere classified \\
\hline NEPA & National Environmental Policy Act \\
\hline $\mathrm{R} \& \mathrm{D}$ & research and development \\
\hline SIC & Standard Industrial Classification \\
\hline TAC & Technical Advisory Committee \\
\hline & Tokamak Fusion Test Reactor \\
\hline
\end{tabular}




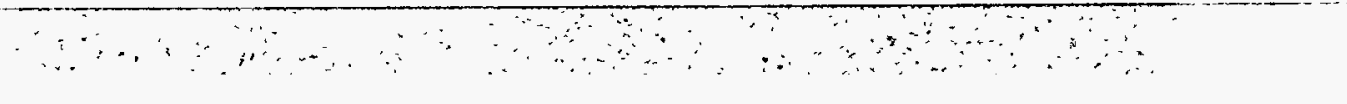




\title{
ECONOMIC IMPACTS ON THE UNITED STATES \\ OF SITING DECISIONS FOR THE INTERNATIONAL \\ THERMONUCLEAR EXPERIMENTAL REACTOR
}

\begin{abstract}
by
J.P. Peerenboom, M.E. Hanson, J.R. Huddleston, T.D. Wolsko, S.H. Pollock, D.S. Meade, T. Allison, D.A. Hanson, A.Z. Rose, A.M. Schaal, and R. Monaco ${ }^{1}$
\end{abstract}

\begin{abstract}
This report presents the results of a study that examines and compares the probable short-term economic impacts of the International Thermonuclear Experimental Reactor (ITER) on the United States (U.S.) if (1) ITER were to be sited in the U.S., or (2) ITER were to be sited in one of the other countries that, along with the U.S., is currently participating in the ITER program. Life-cycle costs associated with ITER construction, operation, and decommissioning are analyzed to assess their economic impact. A number of possible U.S. host and U.S. non-host technology and cost-sharing arrangements with the other ITER Parties are examined, although cost-sharing arrangements and the process by which the Parties will select a host country and an ITER site remain open issues. Both national and local/regional economic impacts, as measured by gross domestic product, regional output, employment, net exports, and income, are considered. These impacts represent a portion of the complex, interrelated set of economic considerations that characterize U.S. host and U.S. non-host participation in ITER. A number of other potentially important economic and noneconomic considerations are discussed qualitatively.
\end{abstract}

\section{INTRODUCTION}

\subsection{BACKGROUND}

The long-term promise of fusion as a safe, economical, abundant, and environmentally acceptable energy source has led the United States (U.S.) and other industrialized nations to actively engage in various fusion research and development (R\&D) programs - both collectively and separately - to harness its power. One such program - the International Thermonuclear

1 Author affiliations are listed in the Preface. 
Experimental Reactor (ITER) program - was initiated in 1988 by the European Community (now known as the European Union), the Soviet Union (Russia is now honoring the former Soviet Union's commitment), Japan, and the U.S. (hereafter referred to as the "Parties"). This multiphase international R\&D program is aimed ultimately at demonstrating the scientific and technological feasibility of magnetic fusion energy. To accomplish this goal, ITER would demonstrate an extended and controlled fusion reaction, demonstrate technologies essential to a fusion reactor in an integrated system, and test the special components required for the practical use of fusion energy. This first-ofa-kind collaborative scientific project represents the next major milestone in the program to develop magnetic fusion as an energy source.

The Parties are currently conducting a six-year Engineering Design Activities (EDA) phase that encompasses the design of the ITER device and its auxiliary systems and facilities. An earlier phase - the Conceptual Design Activities (CDA) phase, which was completed in December 1990 - defined the conceptual design, scope, and mission of the program. As in the CDA phase, work on the EDA phase is being performed under the auspices of the International Atomic Energy Agency (IAEA). An ITER Council, with two government-level representatives from each Party, is responsible for the overall direction of the EDA. A Technical Advisory Committee (TAC) and Management Advisory Committee were established to advise the ITER Council. The costs and benefits of the technology developed through the ITER program are shared equally by the four Parties. Appendix A provides additional information about the ITER program and organization.

In addition to the engineering design work, the site requirements for ITER will also be established during the EDA phase, and a variety of safety, environmental, and economic analyses will be performed. The Parties will use this information to help decide whether to construct ITER, either collaboratively or separately. However, no decisions have been made to commit to construction, and there is no agreed-upon, decision-making schedule at this time. If a decision is made to construct ITER, one Party would likely serve as the "host" Party. The remaining Parties ("non-hosts") would likely participate in constructing and operating the facility and would share the resulting technological benefits. It is expected, for example, that the Parties will share equitably in the contracts to build important technological components of ITER, as well as have access to the designs of all ITER components. Moreover, advanced electronic communication systems are expected to facilitate remote access to the ITER facility, whereby technical personnel in their home institutions can be involved in ITER science and technology experiments (U.S. Department of Energy [DOE] 1994).

The process by which the Parties will select a host country and an ITER site is an open issue. Two basic approaches characterize the range of possibilities being considered. The first approach, referred to as the "Site First" approach, would allow each Party to select and offer a candidate site for consideration. Factors such as cost sharing, distribution of work and contracts, rights and responsibilities of the host Party and the non-host Parties, and the project management structure would likely be negotiated as part of the selection process for a single ITER site. The second approach is referred to as "Party First." In this approach, the host Party would be chosen at 
the outset, following negotiation of the aforementioned factors, rather than having a host site selected from proposals made by the Parties. The host Party would then use a domestic site selection process to choose an appropriate site that meets the requirements agreed upon, subject to acceptance by the other ITER Parties. Among the advantages of the Party First approach is that it would save each of the Parties from assuming the considerable costs of conducting site selection processes.

Regardless of which selection approach is adopted, it is expected that the host Party cost share will be the largest because of the economic benefits derived from being host. Many costsharing arrangements are possible among the non-host Parties (e.g., equal or unequal shares). Like the site selection process, cost-sharing arrangements are an open issue.

\subsection{OBJECTIVE}

The objective of this study is to examine and compare, from a U.S. perspective, the probable short-term economic impacts that would result if the U.S.:

- Serves as the host country for ITER, or

- Participates in the ITER program as a non-host Party.

Both national-level — defined as encompassing the overall U.S. economy - and local/regionallevel — defined as limited to the area immediately serving as the ITER site - economic impacts are examined. Detailed ITER cost analysis data, covering individual ITER system components (e.g., magnets, instrumentation) and the complete ITER life cycle (i.e., construction, operation, decommissioning), are analyzed for a series of alternative U.S. host and U.S. non-host cases. These cases highlight the relative importance of economic analysis parameters and cost-sharing arrangements among the Parties.

Although the study focuses on elucidating the short-term economic impacts associated with U.S. host/non-host participation in ITER, a number of more general issues, pertaining, for example, to potential long-term benefits, are addressed qualitatively in Section 2, which describes the scope of the study, and in Section 6, which summarizes study conclusions and presents observations about the results. Specific study limitations are also discussed in Section 2.

\subsection{STUDY TEAM}

A multidisciplinary team of economists and engineers from academia, the private sector, and the DOE national laboratory system was assembled and managed by Argonne National Laboratory (ANL). Two formal working groups - a National Analysis Working Group and a 
Local/Regional Analysis Working Group - addressed the relevant economic consequences at each level of aggregation. The study was conducted over a six-month period (June-November 1994) for DOE's Office of Fusion Energy.

A series of technical interchange meetings were held to develop a consistent methodological framework for the analysis, to identify common data requirements, and to integrate analysis results. Experts in cost engineering and technology/economic sector characterization provided baseline information to both working groups. Subject-matter experts in other specialized analysis domains guided and advised the study team.

\subsection{REPORT ORGANIZATION}

The remainder of this report is organized as follows. Section 2 defines the scope of the study and describes its limitations. Section 3 discusses the analysis approach followed in conducting the study. Included is a description of the specific analytic models used for the national and local/regional analyses. Section 4 presents assumptions, data sources, and baseline life-cycle cost characterization data. Section 5 presents study findings and analysis results. Section 6 presents various conclusions and observations about the results.

Five appendixes summarize supporting data and provide background descriptions of the analytic models. Appendix A describes the ITER program and organization. Appendixes B through $D$ contain background descriptions of the national and local/regional economic models used in the analyses. Finally, Appendix E contains the detailed life-cycle cost characterization data (in a series of data tables) summarized in Section 4. 


\section{SCOPE OF THE STUDY}

This study addresses a portion of the complex, interrelated set of economic considerations that characterize U.S. host and U.S. non-host participation in ITER. The analysis captures many of the direct and indirect economic impacts associated with ITER construction, operation, and decommissioning and provides insight into the expected magnitude of those impacts. To help put the study into perspective, this section delineates the scope of the study and briefly discusses some of its limitations.

\subsection{PROGRAMMATIC CONTEXT}

Figure 1 depicts the relationship between the ITER program and all of the other U.S. magnetic fusion program activities. ${ }^{2}$ (See Appendix A for a definition and description of these activities.) Collectively, these activities aim to harness fusion energy and provide a basis for

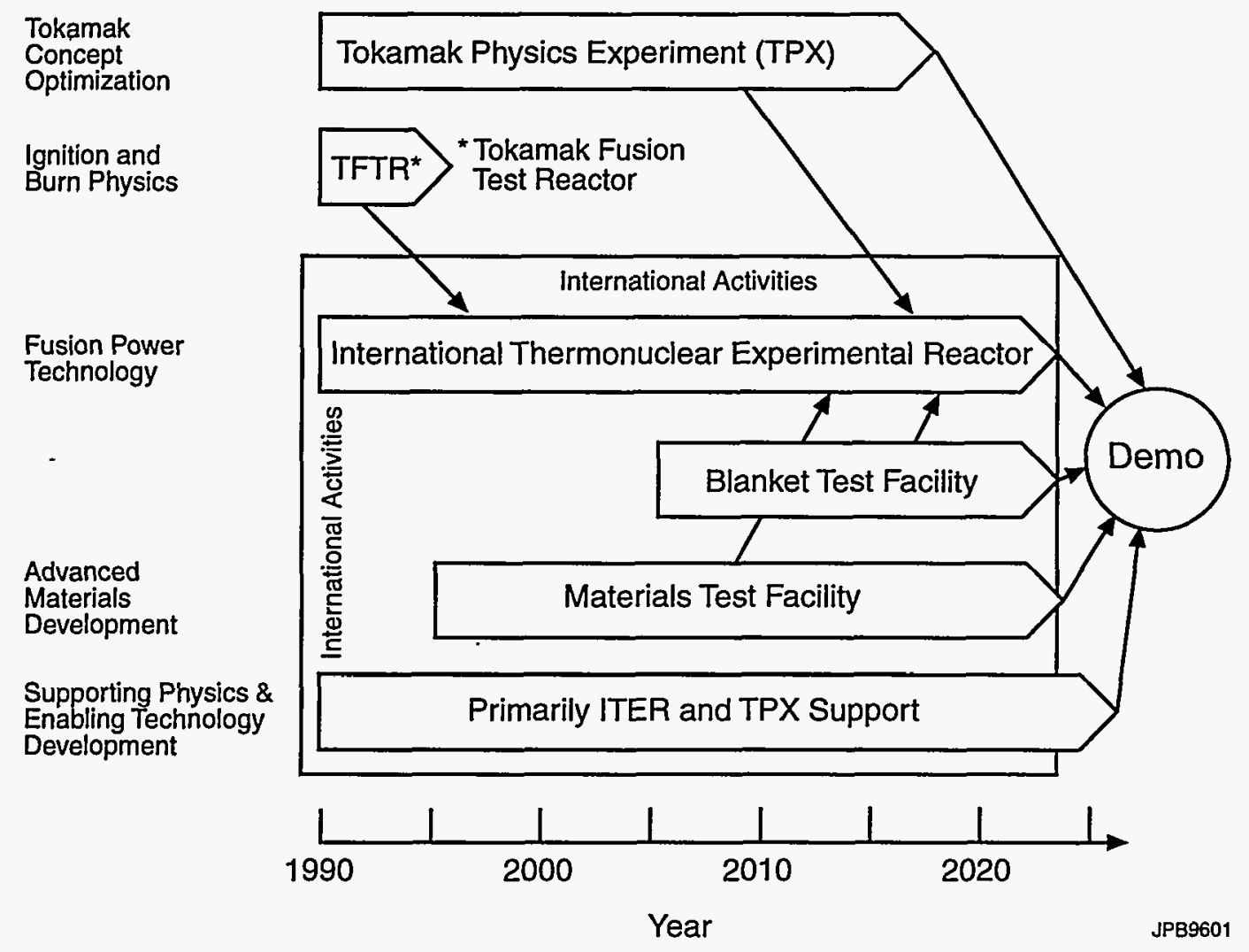

FIGURE 1 ITER in the Context of the U.S. Fusion Energy Programs ${ }^{2}$

2 Although relevant at the time of the study, the figure no longer accurately represents the scope of the present U.S. fusion energy programs. 
designing and building a demonstration facility that would subsequently lead to commercial fusion power facilities. Such a demonstration facility would provide the foundation for realizing the significant long-term potential benefits of fusion energy, namely, a safe, economical, abundant, and environmentally acceptable source of power. Unlike conventional technologies that use fossil fuels, which are rapidly being depleted, fusion uses two forms of hydrogen that are readily available and virtually unlimited. Further, fusion will not produce undesirable combustion products that damage air quality and contribute to global warming and acid rain. Coupled with such benefits are a variety of strategic and technology-related benefits that would extend beyond the fusion arena. Such benefits would include, for example, enhancing the nation's competitiveness and increasing U.S. energy independence.

Within the context of the ITER-related activities shown in Figure 1, this study (1) assumes that a decision to construct and operate ITER will be made; (2) assumes that the U.S. will continue its involvement in the ITER program, thereby benefiting from the international collaboration and cost sharing; and (3) focuses on short-term economic impacts associated with U.S. participation either as the host or non-host Party. The scope of the study is illustrated in Figure 2.

The time horizon examined in this study corresponds to the period defined by ITER construction, operation, and decommissioning. The economic impacts resulting from expenditures on ITER made during this period are categorized as short-term impacts. Long-term economic consequences, including the aforementioned potential economic benefits of fusion as a viable commercial energy source, were not considered. Both national- and local/regional-level economic

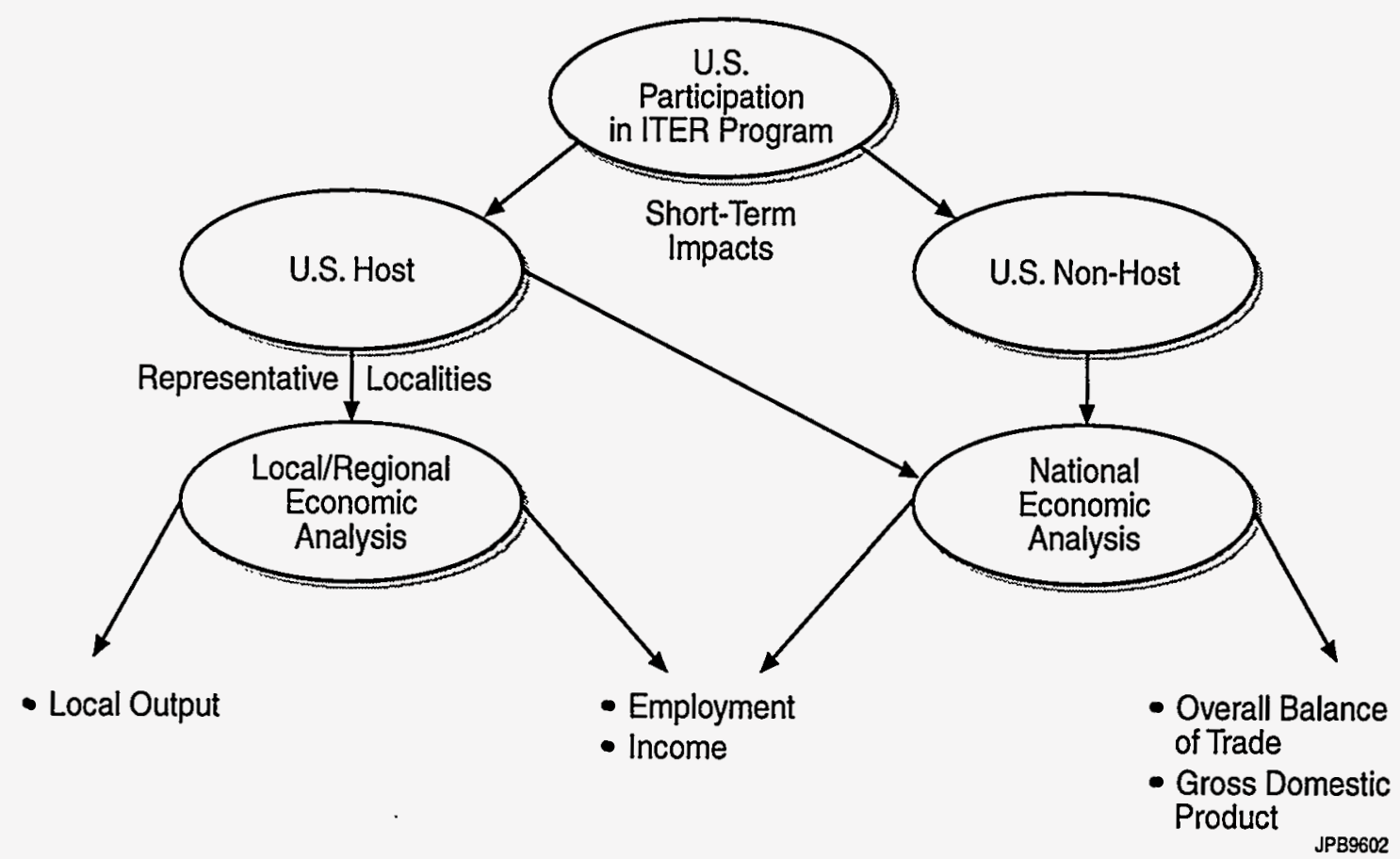

FIGURE 2 Scope of the ITER Economic Study 
impacts were examined for a series of cases predicated on the U.S. serving as the host country for ITER. These impacts included changes in gross domestic product (GDP), employment, net exports, and disposable income at the national level, and changes in local output, employment, and personal income at the local level. Representative localities, rather than specific candidate sites, were considered in the local/regional analysis. National-level economic impacts were considered only for the non-host participation cases. Section 4.5 describes the specific analysis cases examined in the study.

\subsection{ANALYTIC BOUNDARY}

A number of potential costs, benefits, and impacts associated with U.S. participation in the ITER program were not considered in this study. These factors are highlighted in Figure 3, which defines the analytic boundary of the study. Each of the costs, benefits, and impacts shown outside the boundary, and the reason they were not included in the study, is briefly described in the following sections.

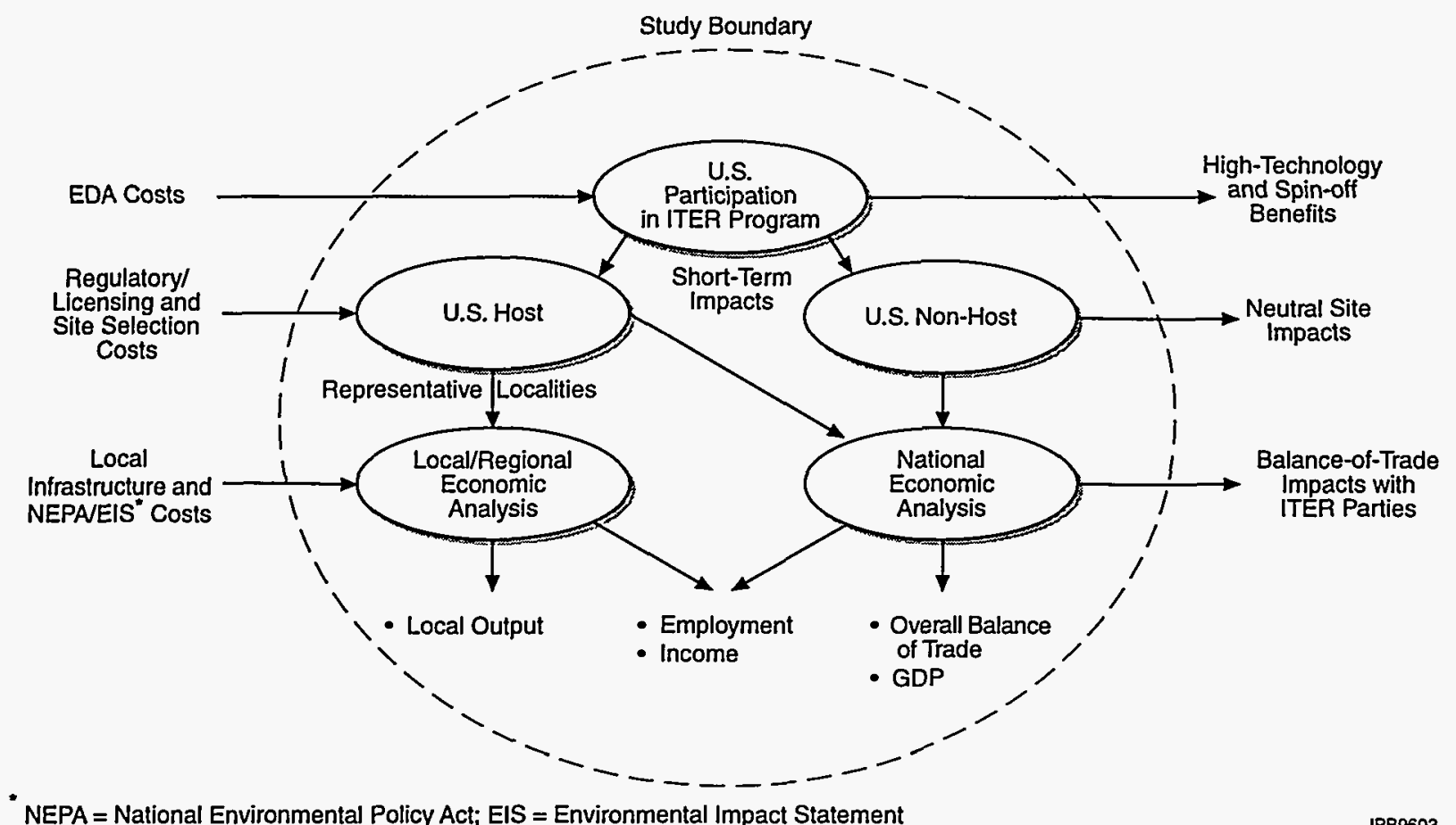

FIGURE 3 ITER Economic Study Boundary 


\subsubsection{EDA Costs}

The U.S., along with the other ITER Parties, formally agreed in July 1992 to participate in the six-year EDA. The costs of the EDA — which were estimated in 1992 at $\$ 1.2$ billion - are being shared equally by the four Parties (DOE 1993a). These preconstruction costs would be incurred whether the U.S. is a host or non-host participant in ITER (i.e., they would have no net economic effect on the study cases); therefore, they were not included in the analysis.

\subsubsection{Regulatory/Licensing Costs}

The costs associated with obtaining approval to site, construct, operate, and decommission an experimental facility such as ITER largely involve costs for government personnel. Because such costs have not been estimated for ITER, and furthermore are typically not included in a facility cost estimate, no regulatory/licensing costs were included in the analysis.

\subsubsection{Site Selection and Preparation Costs}

The process by which the Parties will select a host country and an ITER site has not been finalized and approved. As described in Section 1, several alternatives are being considered, including Party First, which entails selecting the host country without knowing or considering any of the Party's proposed sites, and Site First, which allows each Party to select and offer a site before the host is selected. Within the U.S., a range of options exists for identifying candidate sites. These options include:

- A site competition limited to DOE sites,

- A competition limited to federally owned sites, and

- An open competition of all interested entities.

Some sites may have costs associated with the purchase of land and any clearing or leveling required before construction. Because of uncertainties at the U.S. and international levels relative to the site selection process, and the type of sites to be considered if the U.S. is host, site selection and preparation costs could not be quantified at this time and were not included in the analysis. 


\subsubsection{Local Infrastructure Costs}

The local communities affected by ITER construction, operation, and decommissioning will probably be required to provide additional infrastructure (e.g., roads, transmission lines, sewers) and public services (e.g., police and fire protection, schools) to support ITER life-cycle activities and new residents. Such costs are clearly site dependent. Because specific sites were not examined as part of this study, these potential costs could not be determined.

\subsubsection{NEPA/EIS Costs}

Compliance with the National Environmental Policy Act (NEPA) will be an important consideration if the U.S. begins a process to select a U.S. site for ITER. NEPA requires that an environmental impact statement (EIS) be prepared for the siting, construction, operation, and decommissioning of such facilities. The EIS would (1) consider the need for ITER, the purpose of U.S. participation in ITER, and alternative sites; (2) evaluate site-specific engineering and design alternatives; (3) evaluate site-specific construction and operation alternatives; and (4) evaluate features to mitigate site-specific impacts. Because the site selection process has not been defined, the costs associated with preparing an EIS (or multiple EISs that address ITER siting and ITER construction and operation separately) were not included.

\subsubsection{High-Technology Benefits}

In addition to its direct benefits, ITER would produce industrial and technical knowledge for participants and provide valuable experience for international collaboration in other large, hightechnology projects. A shift from service-sector jobs to high-technology jobs, such as manufacturing superconducting magnets, would also likely occur. Although the economic value of such shifts is difficult to quantify, they do represent a valuable and continuing return from the U.S. involvement in the ITER program. This study did not estimate such benefits.

\subsubsection{Spin -off Benefits}

The innovative solutions developed in addressing the challenges of ITER (and fusion in general) have and are likely to continue to lead to new science and technology applications that benefit many areas beyond the fusion program. The new products and processes developed have increased U.S. competitiveness in many other fields. For example, fusion research has contributed to the development of superconducting magnets, advanced scientific computing, computer-assisted engineering design, plasma processing of semiconductors and other materials, high-power microwave sources, high-heat-flux and radiation-resistant materials, robotics, high-power lasers, and 
high-performance vacuum systems (DOE 1993b; Fusion Power Associates [FPA] 1993). Although the benefits from such spin-offs are potentially significant, they are difficult to predict and quantify in economic terms. This study did not analyze spin-off benefits.

\subsubsection{Neutral Site Impacts}

One alternative to the ITER siting approaches currently being considered, which involve selecting one of the four Parties to be the ITER host, is to site ITER in a "neutral" country. Such an approach might be attractive in that it may simplify siting negotiations and be easier to explicitly demonstrate equity among the four Parties in terms of costs and benefits. The relevance of such a siting alternative, and its implication in terms of costs, was not considered in this study.

\subsubsection{Balance-of-Trade Impacts with ITER Parties}

The national economic models used in this study (Section 3) treated in a generic fashion economic impacts that occur outside the U.S. That is, the economies of the other ITER Parties were not modeled and analyzed. Therefore, balance-of-trade impacts (imports and exports) on each ITER Party for U.S. host and non-host conditions could not be calculated. Only aggregate international trade impacts on the U.S. economy were considered. A complete understanding of the economic consequences of ITER would require an analysis for each ITER Party similar to that presented in this report for the U.S.

\subsection{CAVEATS}

The analysis presented in this report, by design, examines the short-term, direct and indirect economic impacts associated with U.S. participation in the ITER project, either as a host or non-host Party. The economic benefits resulting from such participation (Section 5) therefore should not be viewed as the sole reason for U.S. participation in the ITER project, or more generally, for U.S. fusion R\&D activities. Rather, the justification of ITER - as depicted in Figure 1 - is that it is required for the development of magnetic fusion as an energy source. The potential economic and societal benefits of providing an abundant, environmentally attractive source of power for the future, coupled with the strategic, high-technology, and spin-off benefits described previously, provide the overall justification for fusion $R \& D$ activities.

It is also important to note that study results are sensitive to and depend on (1) study assumptions and (2) preliminary ITER design cost estimates developed as part of the CDA and EDA. Study assumptions, such as those that involve specific ITER component costs, will likely need to be refined on the basis of detailed engineering design and component cost information currently 
being developed as part of the EDA. For example, selection of a specific ITER site will undoubtedly require design modifications that result in refined cost estimates. Moreover, technological breakthroughs in component design and fabrication could also significantly affect the costs of major ITER components. As a result, the ITER cost data used in this analysis should be viewed as representative and subject to change.

Finally, this study only partially addresses the local/regional economic consequences of ITER. For example, estimates of the costs of siting ITER that are incurred by local governments and residents - as well as the site selection and NEPA/EIS costs described previously - were not included in the analysis. Neither were increased local government revenues due to economic activity attributable to ITER. These limitations are a direct result of the fact that specific candidate ITER sites in the U.S. were not identified and examined. Rather, representative localities were used to estimate probable benefits. A complete socioeconomic impact assessment would be required as part of the NEPA/EIS process. 


\section{ANALYSIS FRAMEWORK}

This section describes the study phases, methodological approaches, and analytic models used to examine the short-term economic impacts that would result if the U.S. served as the host country for ITER or participated in the ITER program as a non-host Party.

\subsection{STUDY PHASES}

A simplified representation of the study phases of the ITER economic evaluation is depicted in Figure 4. Two sequential phases are shown. The characterization phase involved (1) characterizing ITER in terms of technological components (systems and subsystems), life-cycle activities, and specific component or activity costs and (2) translating this information into a form usable by the economic models selected for the analysis. The analysis phase involved applying the economic models to examine the national and local/regional economic impacts of U.S. host/non-host participation in ITER.

Determining the appropriate level of data aggregation and representation for the characterization phase and selecting appropriate models for the analysis phase involved identifying or defining the following:

- A set of desired performance indicators for the national and local/regional economic analyses (e.g., change in GDP, regional output, employment);

- Available information about ITER design and component technology;

- Available life-cycle cost data for ITER construction, operation, and decommissioning;

- Study assumptions (e.g., host/non-host cost-sharing arrangements); and

- A set of analysis cases to be examined.

Additional criteria, such as methodological consistency and sensitivity to the expected magnitude of economic impacts, were also considered in selecting the analytic models. The models used in the study are described in Section 3.3. 


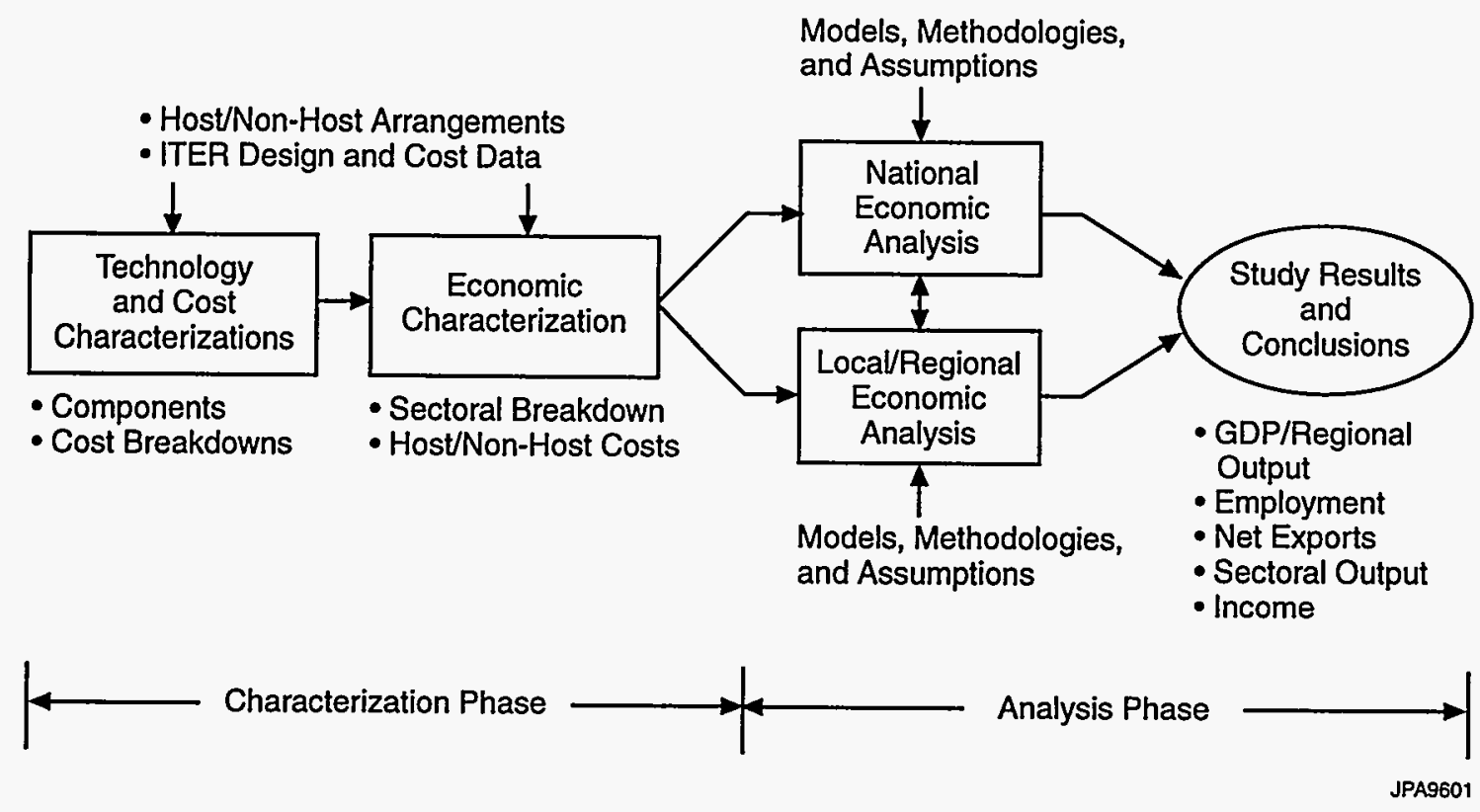

FIGURE 4 Phases of the Economic Study

\subsubsection{Characterization Phase}

The objective of the characterization phase was to translate the ITER technology and timedependent expenditure data, corresponding to specific ITER life-cycle activities, into a form suitable for the analysis models. This translation involved:

- Characterizing ITER in terms of individual, time-dependent expenditures for labor, materials, and equipment;

- Assigning - or mapping - each expenditure to a specific economic sector within the U.S. economy, as defined by Standard Industrial Classification (SIC) codes or Bureau of Economic Analysis (BEA) accounts; and

- Aggregating multiple expenditures assigned to a particular SIC code or BEA account (hereafter referred to as SIC/BEA code) to determine the total expenditure in each economic sector.

Assigning an expenditure to a particular SIC/BEA code implies that the corresponding piece of equipment, material, or service will be supplied by that economic sector. For example, among the many economic sectors that have SIC/BEA codes relevant to ITER construction are those associated with fabricated plate work, fabricated pipe and pipe fittings, and drawing and insulating of nonferrous wire. 
In some cases, several levels of disaggregation were required to properly represent a particular piece of equipment. For example, the ITER magnets can be categorized as specific types of magnets (i.e., torodial field, polodial field, and central solenoid). Each magnet type can then be broken down into labor, material, and equipment components (e.g., coil manufacture, coil material, conductor, mechanical structure). Finally, each of those components can be decomposed further, as necessary, to provide a meaningful sectoral mapping. The mappings for this study are described in Section 4.6.

\subsubsection{Analysis Phase}

The objective of the analysis phase was to evaluate the impact of ITER on the national economy and, when the U.S. is the host Party, on the local area that serves as the site for the ITER project. This evaluation was based on the economic data developed during the characterization phase, and it involved applying national-level and local/regional-level economic analysis tools. To ensure consistency, analytic relationships between the local, national, and global economies were defined to capture key economic interactions. A schematic of these interactions is given in Figure 5 . Both direct and indirect expenditures were considered.

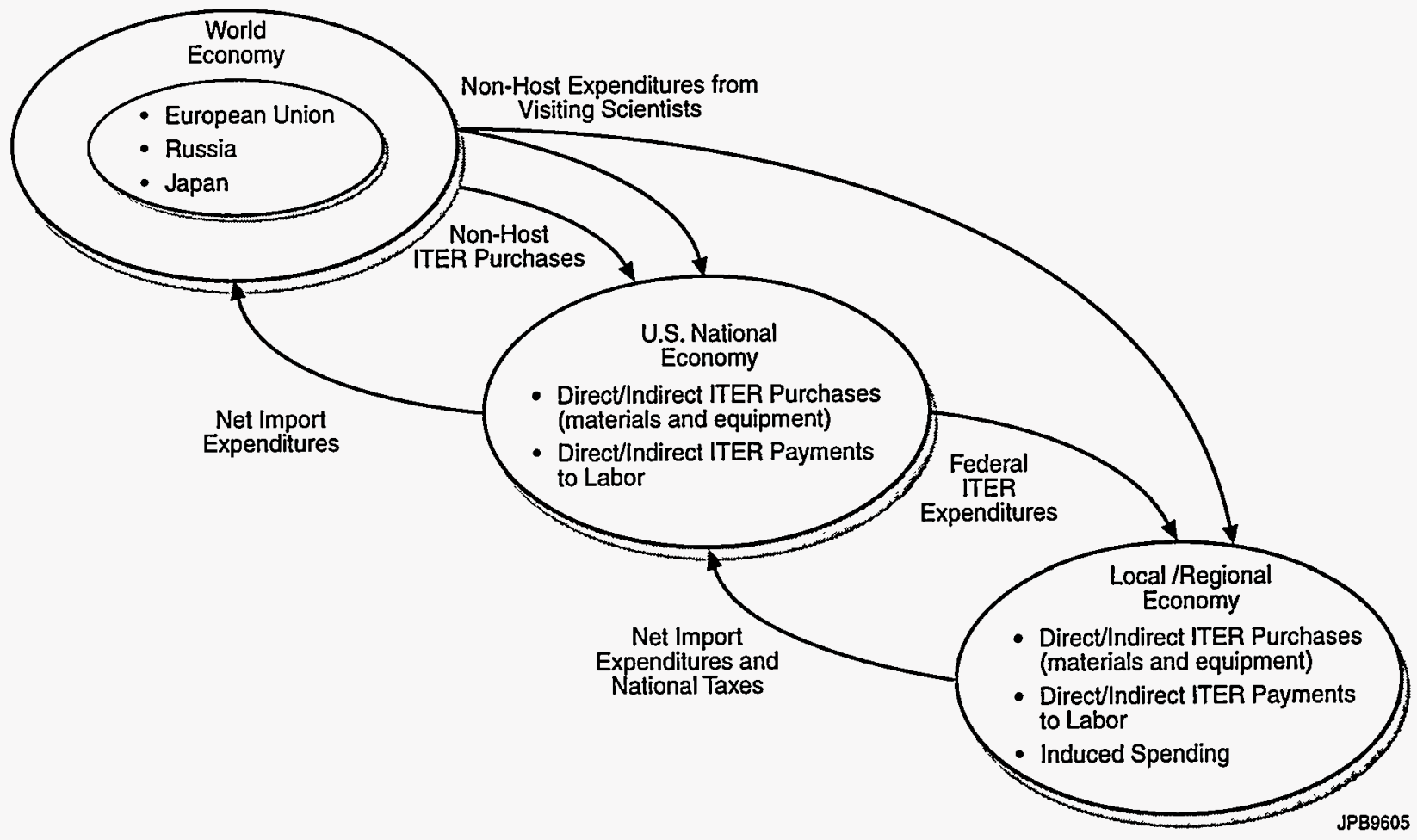

FIGURE 5 Conceptual Framework for National and Local/Regional ITER

Economic Analyses 
The sources of direct ITER expenditures are as follows:

- Expenditures in the U.S. (at both the national and local/regional levels) from the U.S. federal budget for ITER labor, materials, and equipment and

- Expenditures in the U.S. from foreign governments participating in ITER when the U.S. is the host Party. (Under the assumptions of this study, foreign government expenditures in the U.S. are due primarily to the presence of visiting scientists who make purchases during their stay. The non-host Parties would purchase only very small amounts of materials in the U.S.)

Indirect expenditures are more complex. For example, the manufacture of magnets requires a contract for their purchase. The manufacturing company will, in turn, purchase labor, raw and intermediate materials, and equipment with which to fabricate the magnets. The manufacturing equipment also requires inputs for its manufacture. In addition, some ITER indirect expenditures are made for imported materials and equipment, including materials not available in the U.S., such as niobium used in niobium/tin alloy for superconducting cable. The use of foreign sources was determined on the basis of the average performance of the U.S. economy for the particular sector.

Expenditures made outside the area being analyzed are referred to as "leakage." Leakage at the national level is measured as imports. Similar, but proportionately much larger, leakage occurs on the local level, as discussed in Section 3.3. However, much of that leakage, including taxes, goes to the national economy.

\subsection{METHODOLOGICAL APPROACHES}

The step-by-step methodological approaches followed in analyzing the impacts of ITER at the national and local/regional levels are described in the following sections.

\subsubsection{National Analysis Approach}

The national economic analysis evaluated the U.S. national economy with and without ITER. This analysis was limited to short-term impacts, occurring during the ITER life cycle.

Figure 6 summarizes the overall approach (11 elements) to estimating the national economic impacts of ITER. Project characterization data (element 1) and assumptions about host/non-host cost sharing responsibilities (element 2) determine host/non-host expenditure profiles (elements 3 and 4) over the construction, operation, and decommissioning phases of the ITER life cycle. Total ITER spending in the U.S. (element 6 ) when the U.S. is host is the sum of host 


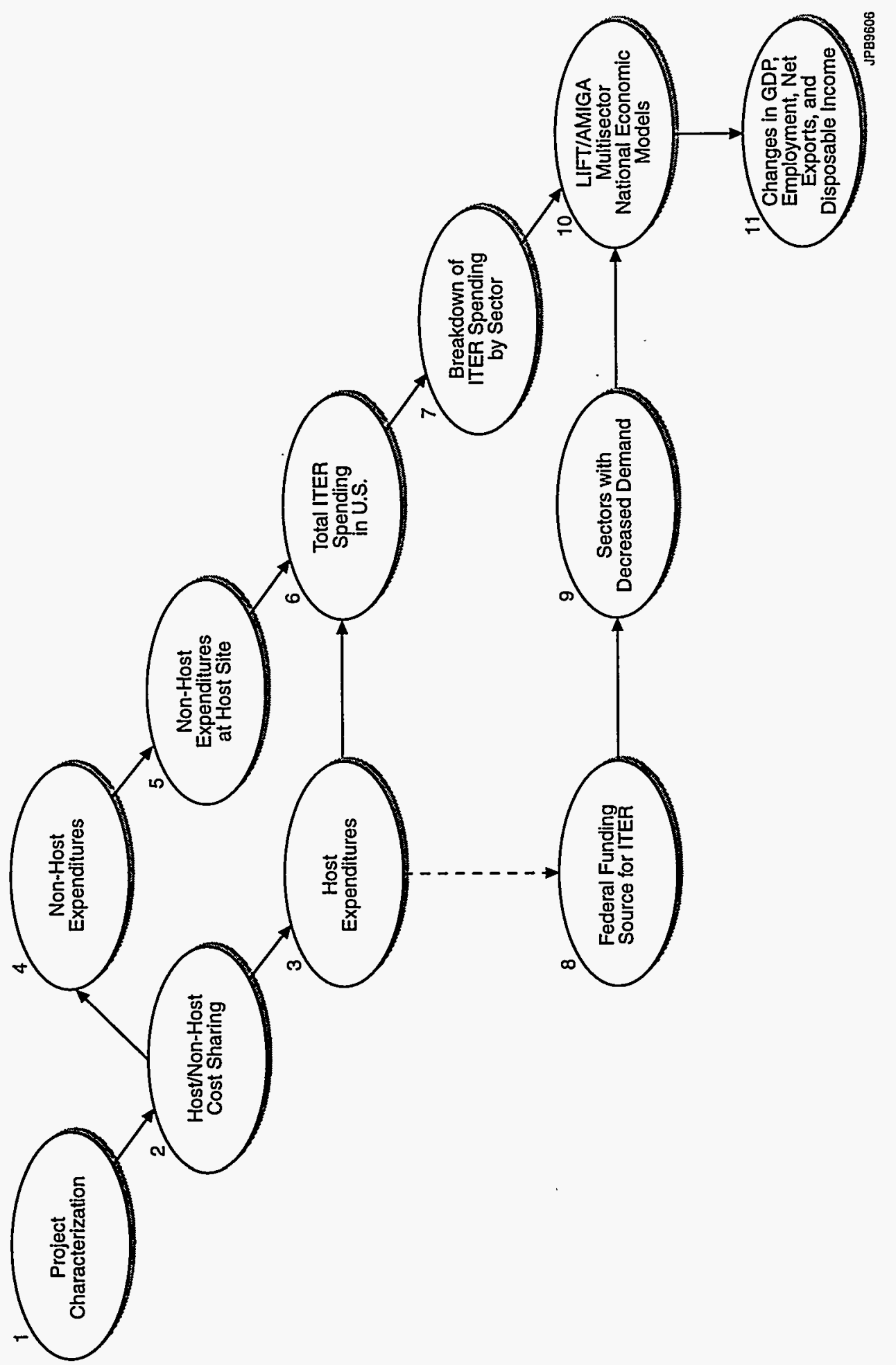

资 
expenditures (element 3) and non-host expenditures at the ITER site (element 5). This spending information is then assigned (mapped) to specific economic sectors (element 7).

The source of federal funding for ITER is a key determinant of national-level economic impacts. Depending on the source of funds (element 8), different economic sectors may experience decreases in demand as funds are committed to ITER (element 9). This information, along with the breakdown of ITER spending by economic sector (element 7), was input to the multisector national economic models (element 10) described in Section 3.3. These models provide a set of common economic performance measures (element 11) defined as follows:

- GDP is an overall measure of the goods and services produced in the national economy, adjusted for imports.

- Employment is a key measure of both overall economic effects and the effects of ITER on specific economic sectors. The study assumed an economy with full employment.

- Net exports are the difference between exports from and imports to the U.S. This indicator measures whether ITER activities increase or decrease the trade deficit.

- Per capita disposable income measures how income changes, on average, as a result of ITER activities. It provides insight into whether the economic activity associated with ITER generates higher- or lower-paying jobs.

\subsubsection{Local/Regional Analysis Approach}

Figure 7 summarizes the approach (10 elements) for estimating local/regional economic benefits of ITER. The primary task of the local/regional analysis was to estimate the portion of total ITER spending (both host and non-host) likely to occur in the local area and its impacts on the local economy. No specific U.S. location has been identified as the site for ITER. Thus, analysis of the probable economic benefits of ITER for a specific location is not possible. It is possible, however, to estimate the benefits that might accrue to a range of locations typical of potential ITER sites. The economic benefits to specific locations will vary, depending on the size and sectoral diversification of each location. These two factors determine the amount of project spending captured in the local economy and the amount that "leaks" out to other locations throughout the U.S. and other countries.

Several metropolitan areas (central cities and surrounding counties) were identified as representative of areas that could support ITER activities (element 8 in Figure 7). These areas were geographically distributed across the U.S. and represented a range of populations. Specific local 


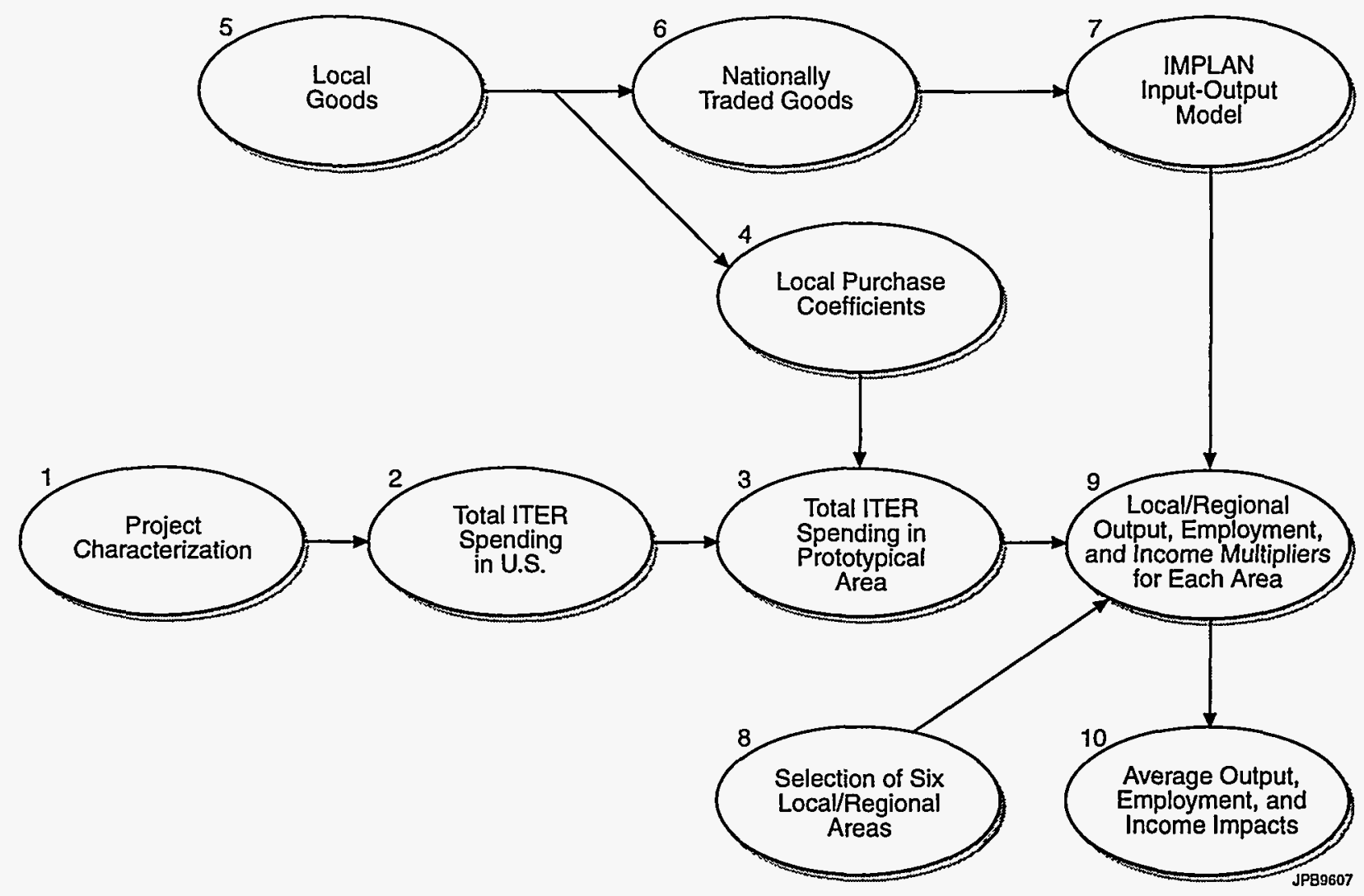

FIGURE 7 Conceptual Framework for Local/Regional Analysis

characteristics, such as availability of water transport and public or private infrastructure, were not considered in selecting these areas.

Local area benefits would be generated by the direct spending (e.g., materials and labor) on ITER construction, operation, and decommissioning and the effects of an expanded local economy. These benefits were measured by changes in local output, employment, and personal income that would likely occur as a result of ITER. Offsetting local costs, such as the cost of providing infrastructure and environmental impact mitigation efforts, was not included in the analysis. Total ITER spending in the local area was derived from the life-cycle cost characterization information developed for the national analysis. In general, expenditures will be made for the purchase of materials and equipment, as well as wages and salaries paid to workers. This process is shown as elements 1 and 2 in Figure 7.

Only a portion of overall ITER spending would occur in the local area. Goods and services purchased from local producers and suppliers would have local economic impacts. Goods and services purchased from producers in other parts of the country would have little impact on the local economy. The local/regional analysis is adjusted for regional purchasing patterns through the use 
of local purchase coefficients (LPCs) (element 4). For example, a high percentage of spending for new buildings at the ITER site will likely be paid to local contractors; only a small percentage of the spending on pipes, valves, and pipe fittings will likely be paid to local producers. The LPCs were based on assumptions regarding whether a good is likely to be locally supplied (element 5) or competitively bid in national markets (element 6). Only new industrial/commercial buildings, new utility structures, ready-mix concrete, and water supply and sewerage services were considered to be primarily locally supplied goods. All other goods and services were assumed to be nationally traded, except electrical services and sanitary services. The portion of nationally traded goods supplied locally was estimated by the use of regional purchase coefficients contained in the inputoutput model used for the analysis (element 7 ).

The ITER project will generate local benefits directly as materials and equipment are purchased from area producers and suppliers and as project workers are paid their wages and salaries. The earnings of area businesses and ITER workers will, in turn, be respent within the local economy many times over. The cumulative effect of this spending and respending in the local economy produces regional multipliers. These multipliers were used to estimate how much additional output, employment, or personal income would be generated from the direct expenditures for ITER. Regional multipliers were estimated for each local area by using input-output models derived from IMPLAN (Impact Analysis for Planning) data series and software (element 9). In particular, sectoral multipliers were estimated for local output (production), employment, and personal income.

The typical local economic benefits to a prospective ITER site were estimated by averaging the sectoral multipliers for the areas considered. The average multipliers were applied to the previously determined estimates of spending in the typical local area to estimate the probable impacts on local/regional output, employment, and personal income (element 10). These estimates, which are reported in Section 5.2, serve as the "centerline" around which specific local conditions would cause variation in expected benefits.

\subsection{ANALYTIC MODELS}

The national and local/regional economic models used in the study represent a methodologically consistent and robust set of analytic tools. As shown in Figure 4, both levels of analysis used the same characterization and sectoral mapping information. Each of the models is described below. 


\subsubsection{National Economic Models}

On the basis of the study objectives, available ITER expenditure and technology information, and desired output economic indicators, a set of requirements was defined for selecting models to estimate the national economic impacts of ITER. Specifically, it was determined that the models must:

- Estimate short-term economic impacts as measured by GDP, employment, net exports, and disposable income;

- Measure the consequences of different federal funding sources for ITER; and

- Determine sectors of the economy that would be affected, positively and negatively, by ITER operations.

Multisectoral economic models generally meet these requirements. However, the ITER study presented a challenging task in that the magnitude of the ITER expenditures - even in the peak year of construction - is expected to be small in comparison to the federal budget and overall U.S. economy. Any national model of the U.S. economy would be near the limits of its capabilities in estimating economic responses to annual expenditures as small as those considered for ITER.

In response to this challenge, two independent models were selected for the analysis. Using identical sets of ITER expenditures (and sectoral mappings) in simulations by the two models would provide additional validation of analytical results beyond the checks available within a single model. The economic changes caused by ITER expenditures, relative to base economic conditions, were compared to evaluate the extent to which the type and magnitude of economic responses were identical or otherwise consistent in the two models.

The two models selected were the LIFT (Long-Term Interindustry Forecasting Tool) model, developed by the Interindustry Forecasting Project of the University of Maryland (INFORUM), and the AMIGA (Argonne Multisector Industrial Growth Assessment) model, developed at ANL.

The LIFT model is a national interindustry model capable of modeling industry relationships as well as macroeconomic behavior such as impacts on the unemployment rate or the balance of payments. It provides information for 85 producing sectors, including output, employment, and prices. Cost information (value added) is included for 51 industries, including labor compensation, profits, depreciation, and net interest payments. LIFT uses an input-output table to track how much each industry buys from all other industries and imports to make its product. Output for any industry is the sum of all of the final demands and intermediate uses. In addition to simulating changes in sectoral and total output, LIFT uses the relationships within the economy to determine employment and prices. LIFT determines macroeconomic variables, such as GDP, 
inflation, the balance of trade, and the employment rate, from the ground up as an aggregate of industry behavior. Other variables, such as interest rates and the personal savings rate, are determined by macroeconomic equations. Thus, LIFT was used to provide a comprehensive analysis of how each sector of the U.S. economy behaves, as a result of the ITER expenditure assumptions, relative to base conditions (McCarthy 1991). Appendix B provides additional background information about LIFT.

The AMIGA model provides a comprehensive picture of the effects of advanced technology developments and related policy scenarios on the U.S. economy. Like LIFT, AMIGA is a computable, multisector model of the economy. The version of AMIGA modified for this study used 225 sectors. Thus, AMIGA operates at a greater level of detail than LIFT. For example, it provides a significant amount of detail about raw materials and material- and energy-intensive goods. Each sector is represented by its production technologies, outputs, and prices. In most sectors, domestic producers compete with imports for the domestic market. AMIGA outputs include GDP, employment, price and wage effects, imports, balance of trade, and production from domestic sectors (Hanson 1994). A more complete description of AMIGA is provided in Appendix C.

\subsubsection{Local/Regional Economic Model}

The IMPLAN input-output model was selected to estimate the local economic benefits of ITER. IMPLAN is a commonly used regional economic analysis system for estimating the overall impact of new technologies in the economies of the areas in which they are located. It includes 1991 information on 528 industries as defined by the U.S. Department of Commerce. The input-output model, as estimated by IMPLAN, presents detailed information on sales and purchases among each of the sectors in a local economy, exports and sales to final demand, and purchases from households and imports. Also included is the proportion of sectoral purchases that come from outside the local economy in the form of imports for each of the sectors in an economy (IMPLAN 1994). Appendix D provides additional information about IMPLAN. 


\section{ASSUMPTIONS AND REFERENCE DATA}

This section identifies key study assumptions, including those that define the ITER life cycle, establish the economic analysis ground rules, and characterize the cost-sharing arrangements among the host and non-host Parties. Reference cost data and life-cycle expenditure profiles are also presented. Finally, the economic analysis cases examined in the study are identified and described.

\subsection{LIFE-CYCLE DEFINITION}

The ITER life cycle consists of three sequential phases: construction, operation, and decommissioning. The construction phase is assumed to begin on January 1, 1999. The duration and timing of each phase is assumed to be as follows:

- Construction: 8 years (1999-2006),

- Operation: 18 years (2007-2024), and

- Decommissioning: 4 years (2025-2028).

Together, these phases define a 30-year study. Costs and/or benefits that occur outside this period are not included in the economic analysis. The reference costs associated with each life-cycle phase are detailed in Section 4.3.

The construction start date (January 1,1999 ) assumes that the EDA phase will be completed as scheduled in July 1998 and that ITER Parties will make timely decisions about such issues as siting, cost sharing, project management, and construction. The start date further assumes that the host Party will have satisfied all domestic siting requirements and completed all necessary site preparation work.

\subsection{ECONOMIC ANALYSIS GROUND RULES}

A set of economic analysis ground rules has been formulated to define how to treat the time-dependent ITER expenditures that occur over the 30-year study. The following ground rules were selected to provide a consistent and understandable basis for the study:

- The reference year for the analysis is 1994, and all costs and study results are expressed in terms of constant 1994 U.S. dollars (i.e., the effects of general inflation were removed from the analysis). 
- "Real" cost escalation, which is defined as a rise in prices over and above the rate of general inflation, is not included in any ITER cost component.

- Cost estimates derived from the CDA (in 1989 and 1993 dollars) and EDA (in 1993 dollars) were converted to 1994 dollars by assuming a uniform annual cost escalation rate of $4 \%$.

- The discount rate, which reflects the opportunity cost of money and is used to convert expenditures that occur at future times to a reference year, is assumed to be zero. The importance of discount rates is discussed in Section 6.

The analysis is performed in constant dollars rather than in current-year dollars in which monetary amounts are expressed in terms of actual prices in each year. The motivation for this decision is that by removing the effects of inflation from the analysis and expressing all costs in constant terms, it is possible to consistently represent and directly compare various years in the time stream of ITER expenditures.

\subsection{REFERENCE COST DATA}

The ITER design and cost data underlying the analysis were derived primarily from information generated during the CDA (completed in 1990) and EDA (currently under way) phases. Three key documents provided the foundation for developing the reference cost estimates used in the study:

- Preliminary ITER Cost \& Schedule Estimates (IAEA 1990),

- ITER CDA Final Report (IAEA 1991), and

- ITER Outline Design Cost Estimate (ITER TAC Meeting No. 4 [TAC-4] 1994).

The last document updates the CDA construction cost estimates provided in the first two documents. It takes into account (1) the overall evolution of the ITER design during the initial stages of the EDA, (2) specific design changes made to decrease ITER costs, and (3) new costing information provided by industry. However, as noted in Section 2.3, firm costing for ITER cannot be determined until the detailed ITER design is complete.

In addition to the aforementioned ITER documents, experience gained in building and operating other large experimental facilities, such as the Tokamak Fusion Test Reactor (TFTR), provided a basis for estimating costs in life-cycle analysis categories not formally addressed in either 
the CDA or the EDA phase. Similarly, to reflect recent experience, the CDA cost estimates were adjusted. However, these estimates have not been reexamined and updated in the EDA phase.

The analysis considered four major cost categories: Construction Capital, Other Construction, Operation, and Decommissioning. The costs associated with each category are described in the following sections.

\subsubsection{Construction Capital}

Table 1 identifies the specific ITER components and activities included in the Construction Capital cost category and highlights cost estimates for these items made during the CDA (in 1989 and 1993 dollars) and EDA (in 1993 dollars) phases. These estimates provide insight into changes (both positive and negative) that occur over time in the cost of each item. For example, the estimates show a dramatic growth in the cost of the toroidal field magnet system (far exceeding the reference $4 \%$ per year cost escalation rate) and a small cost reduction for the fueling and fuel-handling system. The Contingencies cost category adds approximately $20 \%$ to the total cost estimates. This category covers items not explicitly included in the 13 other construction cost categories, but does not cover uncertainties in what is costed.

Table 1 also shows the reference costs (in 1994 dollars), which serve as the baseline for all analysis cases examined in the study. These costs were derived from the EDA cost estimates shown in Table 1 by (1) spreading the EDA contingency costs of $\$ 1.149$ billion (1993 dollars) proportionally among the 13 cost categories; (2) converting the resultant cost estimates from 1993 to 1994 dollars by using the reference annual cost escalation rate of $4 \%$; and (3) normalizing the resultant total construction costs, which include contingencies, to $\$ 6.8$ billion (1994 dollars). The target cost estimate of $\$ 6.8$ billion was derived by escalating a baseline ITER project cost estimate of $\$ 5.6$ billion (1989 dollars) forward to 1994 at $4 \%$ per year.

The contingency costs were spread among the 13 cost categories (rather than being treated as a separate cost category) because the economic analysis models require that each expenditure be assigned (mapped) to a specific economic sector. Such mapping was not possible when the contingencies were represented in an aggregated form. The distribution of contingency costs among the 13 cost categories was assumed to result in a representative mix of expenditures for purposes of the economic sector mapping and subsequent analysis. 
TABLE 1 ITER Construction Capital Cost Estimates (in millions [M] of dollars)

\begin{tabular}{|c|c|c|c|c|c|}
\hline Item & Description & $\begin{array}{c}\mathrm{CDA} \\
(\$ \mathrm{M}[1989])^{\mathrm{a}}\end{array}$ & $\begin{array}{c}\text { CDA } \\
(\$ \mathrm{M}[1993])^{\mathrm{a}}\end{array}$ & $\begin{array}{c}\text { EDA } \\
(\$ \mathrm{M}[1993])^{\mathrm{a}}\end{array}$ & $\begin{array}{c}\text { Reference } \\
\text { Cost } \\
\text { (\$M[1994]) }\end{array}$ \\
\hline 1 & Toroidal field magnet system & 617 & 759 & 1,303 & 1,543 \\
\hline 2 & $\begin{array}{l}\text { Poloidal field magnet system } \\
\text { and central solenoid }\end{array}$ & 271 & 334 & 828 & 981 \\
\hline 3 & $\begin{array}{l}\text { Vacuum vessel and in-vessel } \\
\text { components }\end{array}$ & 730 & 898 & 609 & 721 \\
\hline 4 & Cryostat and vacuum pumping & 141 & 173 & 187 & 221 \\
\hline 5 & Cryoplant & 200 & 246 & 250 & 296 \\
\hline 6 & Heat transport system & 138 & 170 & 277 & 328 \\
\hline 7 & Heating and current-drive systems & 448 & 551 & 140 & 166 \\
\hline 8 & Fueling and fuel-handling system & 177 & 218 & 127 & 150 \\
\hline 9 & Instrumentation and control & 209 & 256 & 250 & 296 \\
\hline 10 & $\begin{array}{l}\text { Power supplies, controls, fluids, } \\
\text { and gases }\end{array}$ & 325 & 400 & 466 & 552 \\
\hline 11 & Buildings and structures & 516 & 634 & 726 & 860 \\
\hline 12 & $\begin{array}{l}\text { Assembly and maintenance } \\
\text { equipment }\end{array}$ & 150 & 184 & 208 & 246 \\
\hline \multirow[t]{2}{*}{13} & Tokamak assembly & 300 & 369 & 370 & 438 \\
\hline & Subtotal & 4,222 & 5,192 & 5,741 & 6,800 \\
\hline \multirow[t]{2}{*}{14} & Contingencies & 1,000 & 1,230 & 1,149 & \\
\hline & Total & 5,222 & 6,422 & 6,890 & \\
\hline
\end{tabular}

a TAC-4 (1994).

\subsubsection{Other Construction}

Three cost items are included in the Other Construction cost category:

- Design and Management.It was assumed that design and management costs would total $\$ 1.9$ billion (1994 dollars). This cost estimate is based on (1) an extrapolation of cost estimates made during the CDA phase (approximately $\$ 800$ million in 1989 dollars) and (2) a recent study commissioned by DOE that indicated that the CDA cost estimate was much too low and that an additional $\$ 1$ billion should be added so that the CDA estimate would be more representative of current expectations (IAEA 1991; Temple and Doggett 1994). 
- $R \& D$ during Construction. It was assumed that technology R\&D - beyond that performed during the EDA phase - would be required during the ITER construction phase. The costs for such $R \& D$ were estimated during the CDA phase to be about $\$ 300$ million in 1989 dollars (IAEA 1991). Applying the reference annual cost escalation rate of $4 \%$ leads to an $R \& D$ cost of approximately $\$ 365$ million (1994 dollars). This value was further increased by $\$ 35$ million (1994 dollars) because it was assumed that the additional design work cited above would result in additional R\&D. The resulting reference cost estimate totals $\$ 400$ million (1994 dollars).

- Preparation for Operation. A preliminary average annual operating cost for ITER of approximately $\$ 270$ million (1989 dollars) was estimated during the CDA (IAEA 1990, 1991). During the 18-year operating life of the facility, this annual cost amounts to about $\$ 4.9$ billion, which includes $\$ 1.6$ billion for personnel, $\$ 750$ million for energy, $\$ 2.1$ billion for spare parts, $\$ 250$ million for fuel, and $\$ 200$ million for other items. Applying the reference annual cost escalation rate of $4 \%$ over the 1989-1994 period yields an average annual operating cost of approximately $\$ 320$ million (1994 dollars). On the basis of recent experience in preparing for the operation of large experimental $R \& D$ facilities, it was assumed that three years will be required to prepare for ITER operation. Assuming that annual expenditures over this three-year period are approximately equal to the estimated average annual operating cost of $\$ 320$ million, a total preparation for operation cost of $\$ 900$ million (1994 dollars) was estimated.

Collectively, the three cost items in the Other Construction category total $\$ 3.2$ billion (1994 dollars).

\subsubsection{Operation}

Two cost items are included in the Operation category:

- Tokamak Operation. As noted under Preparation for Operation, an average annual operating cost of $\$ 320$ million (1994 dollars) was derived from estimates made during the CDA phase. This annual expenditure totals $\$ 5.76$ billion (1994 dollars) over the 18-year life of the facility and includes the costs associated with electricity, cryogens, fuel, and other supplies. It also provides for routine modifications to, and changes in, ITER components.

- Experiments. The annual cost of experiments was assumed to be $\$ 160$ million (1994 dollars). This cost is based on preliminary cost estimates made during 
the CDA phase. The costs associated with adding a breeding blanket to ITER are included. The total life-cycle expenditure for experiments was estimated at $\$ 2.88$ billion (1994 dollars).

Over the 18-year operating life of the facility, the two Operation cost items total $\$ 8.64$ billion (1994 dollars).

\subsubsection{Decommissioning}

Decommissioning costs were estimated at $\$ 1$ billion (1994 dollars). This estimate is based on (1) an extrapolation of estimated TFTR decommissioning costs and (2) recent experience with commercial fission reactors. The $\$ 1$ billion is assumed to cover the costs associated with removal and disposal of the radioactive components and all other ITER components that have no remaining useful life. The buildings were assumed to be available for future fusion devices or other comparable uses. No salvage value was included in the study; that is, any benefits to be realized from the disposal or use of ITER facilities at the end of its life in 2028 were assumed to accrue to the host Party.

\subsubsection{Summary of Reference Costs}

Table 2 summarizes the complete set of life-cycle reference cost data used in the study. As shown, the detailed reference cost data listed in Table 1 have been aggregated into five cost items listed under Construction Capital (i.e., buildings and structures, tokamak magnets, tokamak other, auxiliaries, and assembly). Figure 8 depicts the cost of each item as a fraction of Construction Capital, along with a cost breakdown for tokamak magnets, which are the largest expense. When combined, the Construction Capital and Other Construction categories result in a total construction cost estimate of $\$ 10$ billion (1994 dollars). The two Operation categories total $\$ 8.64$ billion (1994 dollars). Figure 9 depicts the fraction of the total life-cycle cost $-\$ 19.64$ billion (1994 dollars) represented by each of the four aggregate cost categories.

\subsection{EXPENDITURE PROFILES}

Expenditures associated with the construction, operation, and decommissioning phases are incurred over 8-, 18-, and 4-year time periods, respectively. This analysis assumed that the reference costs shown in Table 2 were distributed over these time periods as follows:

- Costs in the Construction Capital category were distributed over the 8-year construction period, which would begin on January 1, 1999 (Table 3). 
TABLE 2 Summary of ITER Life-Cycle

Reference Costs (in billions of 1994 dollars)

\begin{tabular}{|c|c|c|}
\hline Cost Category & $\begin{array}{c}\text { Reference } \\
\text { Cost }\end{array}$ & $\begin{array}{l}\text { Total } \\
\text { Cost }\end{array}$ \\
\hline Construction Capital & & 6.80 \\
\hline Building and structures ${ }^{a}$ & 0.86 & \\
\hline Tokamak magnets ${ }^{\mathrm{b}}$ & 2.52 & \\
\hline Tokamak other ${ }^{c}$ & 1.80 & \\
\hline Auxiliaries ${ }^{\mathrm{d}}$ & 1.18 & \\
\hline Assembly & 0.44 & \\
\hline Other Construction & & 3.20 \\
\hline Design and management & 1.90 & \\
\hline $\mathrm{R} \& \mathrm{D}$ during construction & 0.40 & \\
\hline Preparation for operation & 0.90 & \\
\hline Total Construction & & 10.00 \\
\hline Operation (18 years) & & 8.64 \\
\hline $\begin{array}{l}\text { Tokamak operation } \\
\text { (\$320 million/yr) }\end{array}$ & 5.76 & \\
\hline $\begin{array}{l}\text { Experiments } \\
\text { (\$160 million/yr) }\end{array}$ & 2.88 & \\
\hline Decommissioning & & 1.0 \\
\hline Total & & 19.64 \\
\hline
\end{tabular}

a Cost item 11 in Table 1.

b Cost items 1 and 2 in Table 1.

c Cost items 3, 4, 7, 8, 9, and 12 in Table 1.

d Cost items 5, 6, and 10 in Table 1.

e Cost item 13 in Table 1. 
Total Construction Capital Cost: $\$ 6.8$ Billion

(costs shown are in billions of dollars)
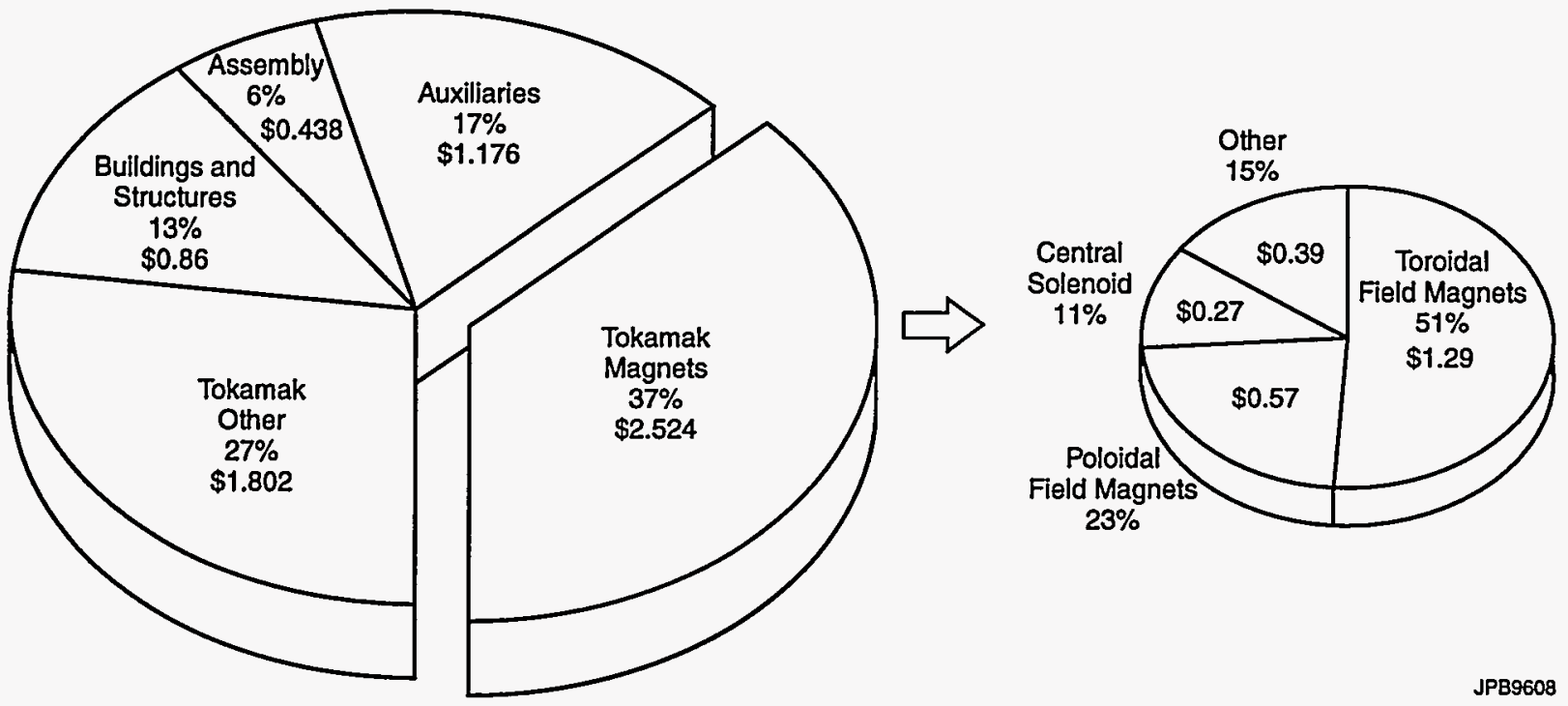

FIGURE 8 Distribution of ITER Construction Capital Costs and Tokamak Magnet Costs

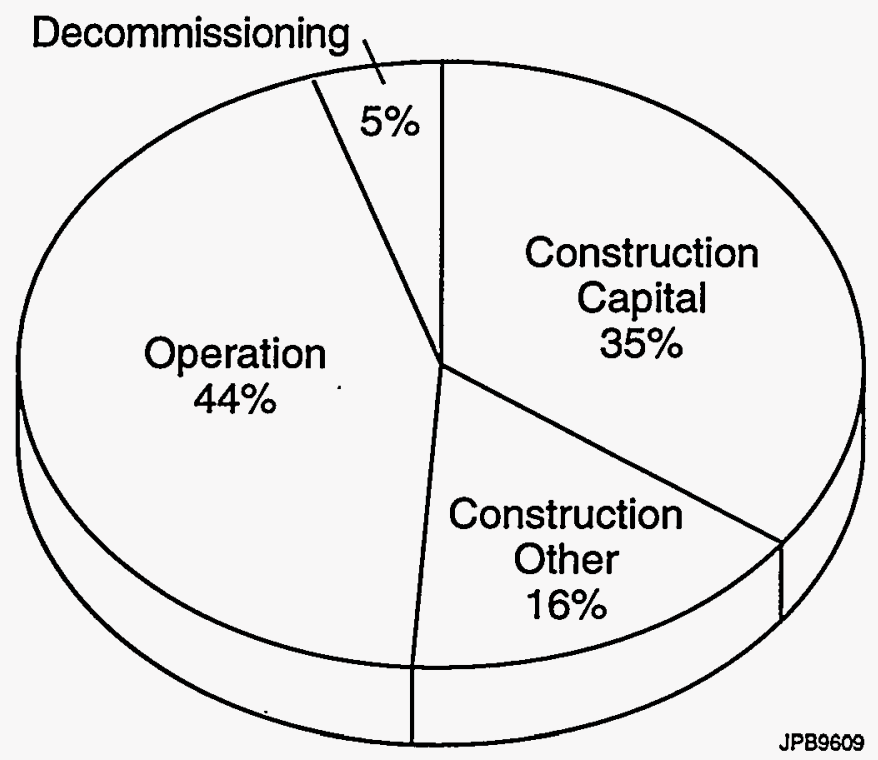

FIGURE 9 Distribution of ITER Life-Cycle Costs 
- Expenditures associated with the Design and Management and R\&D during Construction categories were distributed uniformly over the 8-year construction period (Table 3).

- Expenditures associated with the Preparation for Operation category were assumed to be incurred during the last three years of construction (i.e., years 6-8) and were distributed as shown in Table 3.

- Costs associated with the Tokamak Operation and Experiments categories, which would be incurred from 2007 through 2024, are assumed to be distributed uniformly over the 18-year operating life.

- Decommissioning costs, which would be incurred from 2025 through 2028, are assumed to be distributed uniformly over the 4-year decommissioning period (i.e., $25 \%$ of the total cost is incurred each year).

\subsection{ANALYSIS CASES}

The analysis cases examined in this study are defined by three major characteristics: (1) assumptions about host/non-host cost-sharing responsibilities relative to the cost categories shown in Table 2 and assumptions about the fraction of non-host expenditures incurred at the host site, (2) the location of the facilities used to assemble the tokamak magnets, and (3) the source of federal funding for U.S. participation in ITER.

\subsubsection{Cost-Sharing Assumptions}

The cost-sharing arrangements among the host and non-host Parties were assumed to be based on the same principle of international collaboration and cooperation that has been the hallmark

TABLE 3 Expenditure Profiles for ITER Construction

\begin{tabular}{lcccccccc}
\hline & \multicolumn{7}{c}{ Expenditures per Year of Construction (\%) } \\
\cline { 2 - 9 } \multicolumn{1}{c}{ Cost Category } & 1 & 2 & 3 & 4 & 5 & 6 & 7 & 8 \\
\hline Construction Capital & 5 & 15 & 20 & 20 & 15 & 10 & 10 & 5 \\
Design and Management & 12.5 & 12.5 & 12.5 & 12.5 & 12.5 & 12.5 & 12.5 & 12.5 \\
R\&D during Construction & 12.5 & 12.5 & 12.5 & 12.5 & 12.5 & 12.5 & 12.5 & 12.5 \\
Preparation for Operation & 0 & 0 & 0 & 0 & 0 & 30 & 35 & 35 \\
\hline
\end{tabular}


of the CDA and EDA phases. That is, it was assumed that all Parties would share equally in the technological benefits of ITER and that the direct transfer of funds across borders would be minimized. In support of these objectives, it was assumed that all Parties would share equally in high-technology task costs, such as R\&D and procurement of equipment. In addition, it was assumed that each non-host Party would have a monitor/control station at home so that technical personnel in their home institutions could be involved in ITER science and technology (S\&T) experiments. This assumption reduces the transfer of funds - in the form of expenditures by visiting ITER scientists - from the non-host Parties' economies to the host Party economy.

Consistent with the CDA and EDA phases, it was assumed that the four Parties - a host Party and three non-host Parties - would share the costs associated with ITER construction, operation, and decommissioning. For this study, the financial responsibility of each non-host Party was assumed to be identical. Arrangements involving either a smaller or a larger number of costsharing Parties and unequal cost sharing among the non-host Parties are discussed qualitatively in Section 6.

Two specific cost-sharing arrangements among the host and non-host Parties were examined. The study cases corresponding to these arrangements - denoted the reference case and the increased non-host participation case - were developed by using a "bottom-up" approach in which specific cost-sharing assumptions were made for each life-cycle phase and activity.

The reference case assumed that (1) the host Party supplies buildings and structures; (2) the Parties share equally in the high-technology procurement in the Tokamak Magnets, Tokamak Other, and Auxiliaries categories; (3) the tokamak magnet winding occurs at the host site; (4) the host Party provides $50 \%$ of the tokamak assembly labor; (5) the Parties share equally in the costs associated with the Design and Management, R\&D during Construction, and Experiments categories; and (6) decommissioning is a host responsibility, with no cost sharing. Table 4 summarizes these assumptions and also shows the assumed fraction of non-host costs incurred at the host site and in the home country.

As indicated in Table 4, non-host costs associated with assembling ITER and winding the tokamak magnets were assumed to be incurred at the host site. R\&D during construction was assumed to occur at home-country institutions. Similarly, high-technology procurements, such as magnet subcomponents, by the non-host Parties would also occur at home. Other non-host expenditures would be divided between the host site and home country to minimize the transfer of funds across borders. The monitoring/control stations in the non-host countries were assumed to allow most of the non-host expenditures in the Tokamak Operation category to be spent in the home country.

When the cost-sharing assumptions shown in Table 4 are applied to the reference costs in Table 2, the overall host and non-host cost-sharing responsibilities can be determined. These 
TABLE 4 Host/Non-Host Cost Sharing Arrangements:

Reference Case

\begin{tabular}{lccc} 
& & \multicolumn{2}{c}{$\begin{array}{c}\text { Non-Host Cost Each } \\
\text { Party (\%) }\end{array}$} \\
\cline { 3 - 4 } & & At Host & At \\
& & Host Cost \\
\multicolumn{1}{c}{ Cost Category } & $(\%)$ & Site & Home \\
\hline & & & \\
Construction Capital & 100 & 0 & 0 \\
Building and structures & 25 & 5 & 20 \\
Tokamak magnets & 25 & 0 & 25 \\
Tokamak other & 25 & 0 & 25 \\
Auxiliaries & 50 & 17 & 0 \\
Assembly & & & \\
Other Construction & 25 & 10 & 15 \\
Design and management & 25 & 0 & 25 \\
R\&D during construction & 40 & 10 & 10 \\
Preparation for operation & & & \\
Operation & 50 & 7 & 10 \\
Tokamak operation & 25 & 10 & 15 \\
Experiments & 100 & 0 & 0 \\
Decommissioning & & & \\
\hline
\end{tabular}

responsibilities are depicted in Figure 10. Overall, the host is responsible for $\$ 7.99$ billion (40\%) of the total life-cycle costs, and each non-host Party is responsible for $\$ 3.88$ billion (20\%). This $40 / 20 \%$ cost split is equivalent to dividing the total ITER life-cycle costs into five shares: the host country is responsible for two shares, and each of the three non-host countries is responsible for one share. The specific host/non-host cost breakdowns for each cost category are shown in Figure 11.

The annual expenditure profiles over the 30-year study for the host and non-host Parties are shown in Figure 12. The peak expenditure level ( $\$ 1.65$ billion) is incurred during the third and fourth years of construction. The host/non-host expenditures during these years total $\$ 563$ million and $\$ 362$ million
Total Life-Cycle Cost: $\$ 19.64$

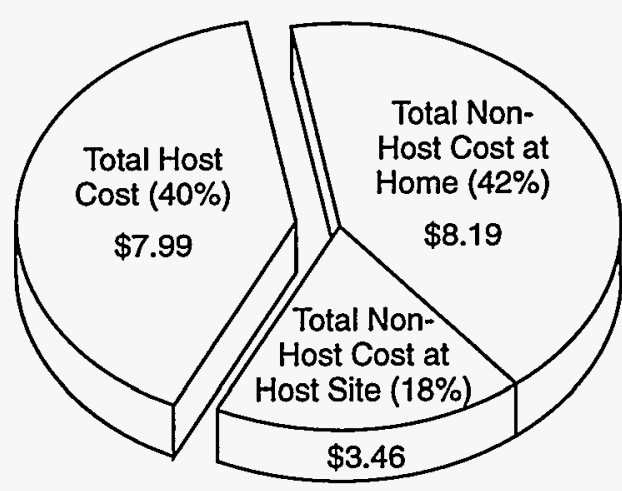

(in billions of 1994 dollars)

JPA9602

FIGURE 10 Distribution of Host/NonHost Costs: Reference Case (in billions of 1994 dollars) 


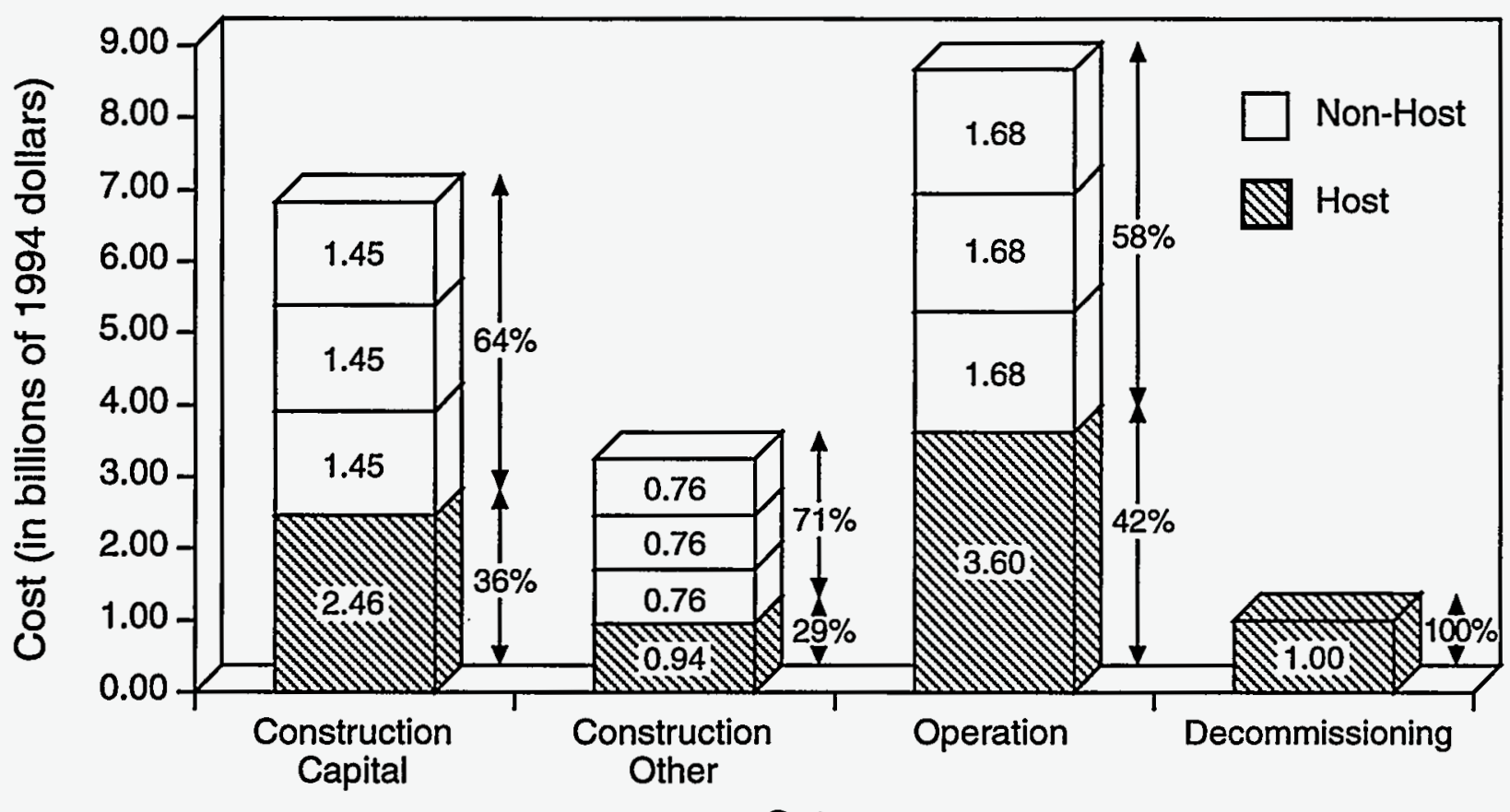

Category

JPB9611

FIGURE 11 Summary of Host/Non-Host Costs by Category: Reference Case

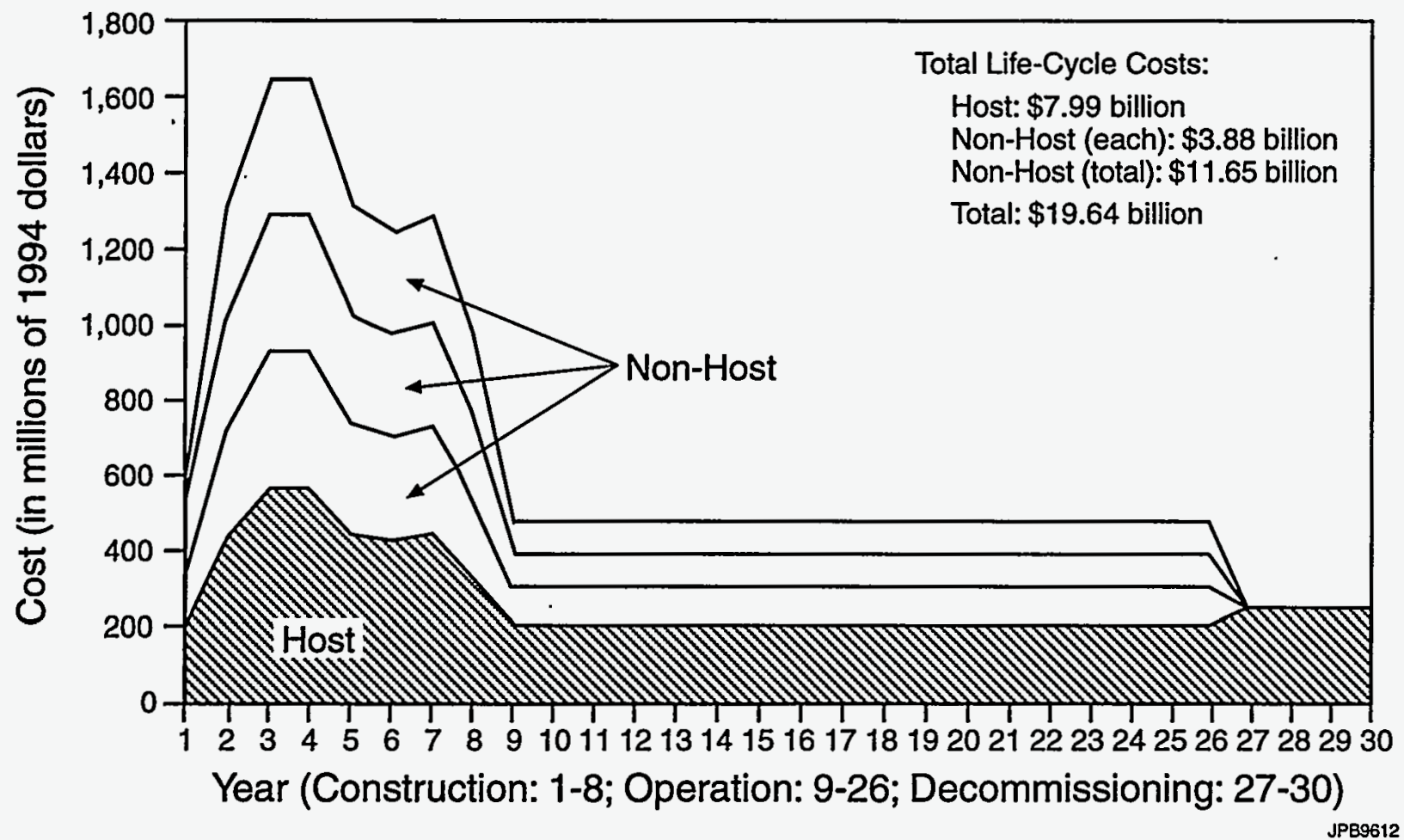

FIGURE 12 Cumulative Annual Host and Non-Host Costs: Reference Case 
(each non-host Party), respectively. The annual host/non-host expenditures during the operation phase total $\$ 200$ million and $\$ 93$ million (each non-host Party), respectively.

In the increased non-host participation case, it was assumed that (1) the non-host Parties contribute to decommissioning (10\% each), and (2) a greater level of non-host participation occurs in the ITER assembly (increasing from 17 to $20 \%$ each in the reference case). The other reference case assumptions remain the same. When non-host Parties contribute to decommissioning and increase their participation in ITER assembly, the host share of the total life-cycle cost decreases by approximately $\$ 340$ million (from $\$ 7.99$ billion to $\$ 7.65$ billion), while the non-host share (each Party) increases by approximately $\$ 120$ million (from $\$ 3.88$ billion to $\$ 4.0$ billion).

\subsubsection{Magnet Assembly}

The reference case assumed that both host/non-host Parties would build the subcomponents for the tokamak magnets (i.e., toroidal field, poloidal field, and central solenoid magnets) at homecountry sites and then ship them to the host site for final winding. As indicated in Table 4, 5\% of the magnet costs incurred by each non-host Party for the winding process is assumed to be spent at the host site. The magnet option case assumed that the toroidal field and central solenoid magnets are completely assembled at home-country sites and shipped to the host site for integration into the reactor. However, the poloidal field magnets are assumed to be so large that they must be assembled at the host site. This assumption reduces the expenditures by each non-host Party at the host site by $\$ 97$ million (from $\$ 133$ million to $\$ 36$ million).

\subsubsection{Source of ITER Funds}

A critical determinant of the way the national economy responds to ITER is the manner in which ITER is funded within the U.S. federal budget. In particular, a specific project (such as ITER) can be funded either through new federal expenditures or by realignment of previously budgeted expenditures. If a future federal project is to be funded by new expenditures, either new sources of tax revenues must be identified or additional debt must be incurred.

This study considers realignment as well as debt funding of ITER. The latter option stimulates the economy in the short term because of the additional spending. The realignment option has a far more subtle effect in that overall federal expenditures stay the same, although the mix of economic activity changes with the realignment of budget from one set of activities to another. This study considers three specific funding alternatives:

- Realignment of the discretionary federal nondefense budget, 
- Realignment of the federal nondefense S\&T budget, and

- New (supplemental) federal budget expenditures.

The realignment of the federal nondefense budget was assumed to be the source of funds in the reference case.

\subsubsection{Summary of Study Cases}

Table 5 summarizes the five analysis cases examined in this study. As shown, the life-cycle cost characterization information for the reference case also applies to the S\&T budget realignment and supplemental budget cases. While these "budgeting" sensitivity cases affect national-level economic indicators (e.g., GDP and sectoral outputs), they do not affect the host/non-host cost breakdowns.

TABLE 5 Overview of Study Cases

\begin{tabular}{|c|c|c|}
\hline Case Name & $\begin{array}{l}\text { Key Host/Non-Host } \\
\text { Assumptions }\end{array}$ & $\begin{array}{l}\text { Source of ITER Funds } \\
\text { within U.S. Economy }\end{array}$ \\
\hline Reference & $\begin{array}{l}\text { - Buildings and structures supplied by } \\
\text { host } \\
\text { - Magnets wound at host site } \\
\text { - Host responsible for } \\
\text { decommissioning } \\
\text { - Monitor/control station at home for } \\
\text { each non-host Party }\end{array}$ & $\begin{array}{l}\text { Realignment of discretionary } \\
\text { federal nondefense budget }\end{array}$ \\
\hline $\begin{array}{l}\text { S\&T Budget } \\
\text { Realignment }\end{array}$ & Same as reference case & $\begin{array}{l}\text { Realignment of federal S\&T } \\
\text { budget }\end{array}$ \\
\hline Supplemental Budget & Same as reference case & New federal budget expenditures \\
\hline $\begin{array}{l}\text { Increased Non-Host } \\
\text { Participation }\end{array}$ & $\begin{array}{l}\text { - Non-host Parties contribute to } \\
\text { decommissioning } \\
\text { - Greater non-host participation in } \\
\text { ITER assembly }\end{array}$ & Same as reference case \\
\hline Magnet Option & $\begin{array}{l}\text { Toroidal field and central solenoid } \\
\text { magnets manufactured at home } \\
\text { locations } \\
\text { Poloidal field magnets wound at } \\
\text { host site }\end{array}$ & Same as reference case \\
\hline
\end{tabular}


Each of the five cases was analyzed with respect to the U.S. economic consequences, with the U.S. either serving as the host country for ITER or participating in ITER as a non-host Party. Only the reference and increased non-host participation cases were examined with respect to local/regional economic consequences. This dichotomy between the national and local/regional analysis cases reflects the fact that the source of ITER funds within the U.S. economy is relevant only at the national level. Section 5 presents the results of the analysis for these cases.

\subsection{SECTORAL MAPPING}

As described in Section 3.2, each ITER expenditure was assigned - or mapped - to a specific economic sector, as defined by a standard SIC/BEA code. This mapping involved breaking down the major cost categories identified in Table 2 into more than 170 individual cost items assigned to specific sectors. Table 6 provides an example of this detailed mapping for the toroidal field magnet system. As shown, individual labor, material, and equipment items are identified and assigned to specific sectors, as defined by SIC/BEA codes. Total expenditures for toroidal field magnet construction summed over all of the sectors are $\$ 1,543$ million, as described in Table 1 .

Expenditures assigned to the same SIC/BEA code were then aggregated (e.g., SIC codes 1799 and 3441 in Table 6), resulting in 54 distinct economic-sector assignments. This aggregated information is presented in Table 7, which (1) identifies the applicable SIC/BEA code, (2) briefly describes the economic sector, and (3) details the expenditure information. All labor, material, and equipment costs are included in Table 7. The sum of the individual expenditures over the 54 sectors is $\$ 19.64$ billion (1994 dollars). 


\section{TABLE 6 Sectoral Mapping for ITER Toroidal Field Magnet System}

\begin{tabular}{|c|c|c|c|}
\hline Item Description & $\begin{array}{c}\operatorname{Cost}^{\mathrm{a}} \\
(1994 \$)\end{array}$ & $\begin{array}{l}\text { SIC } \\
\text { Code }\end{array}$ & Code Description \\
\hline \multicolumn{4}{|l|}{ TF coil manufacturing ${ }^{\mathrm{b}}$} \\
\hline TF conductor & 406 & 3357 & $\begin{array}{l}\text { Drawing and insulating nonferrous } \\
\text { wire }\end{array}$ \\
\hline TF coil material & 83 & 3443 & Fabricated platework \\
\hline Tools and capital equipment & 462 & 354 & $\begin{array}{l}\text { Metalworking machinery and } \\
\text { equipment }\end{array}$ \\
\hline Labor & 340 & 1799 & Special trade contractors, $N^{2} C^{c}$ \\
\hline TF buswork and cooling & 18 & 3498 & Fabricated pipe and pipe fittings \\
\hline \multicolumn{4}{|l|}{ TF mechanical structure assembly } \\
\hline Material & 50 & 3443 & Fabricated platework \\
\hline Labor & 63 & 1799 & Special trade contractors, NEC \\
\hline Tooling & 44 & 354 & $\begin{array}{l}\text { Metalworking machinery and } \\
\text { equipment }\end{array}$ \\
\hline Program management & 5 & 8711 & Engineering services \\
\hline TF coil keys & 34 & 3441 & Fabricated structural metal \\
\hline Gravity supports & 27 & 3441 & Fabricated structural metal \\
\hline Instrumentation & 12 & 3829 & Electrical industrial apparatus, NEC \\
\hline Total cost & 1,543 & & \\
\hline
\end{tabular}

a Cost is in millions of dollars.

b $\mathrm{TF}=$ toroidal field.

c $\mathrm{NEC}=$ not elsewhere classified. 
TABLE 7 Mapping of ITER Expenditures to Econiomic Sectors

\begin{tabular}{|c|c|c|c|}
\hline Sector & $\begin{array}{c}\text { SIC/BEA } \\
\text { Code }^{\mathrm{a}}\end{array}$ & Total $\operatorname{Cost}^{\mathrm{b}}$ & Keyword/Detailed Description \\
\hline Instaliation or erection of building equipment, $\mathrm{NEC}^{\mathrm{C}}$ & 1796 & 462 & $\begin{array}{l}\text { Power-generating equipment installation contractors; installation of } \\
\text { machinery and other industrial equipment }\end{array}$ \\
\hline Special trade contractors, NEC & 1799 & 694 & - \\
\hline Chemicals and allied products & 28 & 81 & $-d$ \\
\hline Industrial gases & 2813 & 180 & Compressed, liquefied, or solid, $\mathrm{N}_{2}, \mathrm{He}, \mathrm{O}_{2}, \mathrm{H}, \mathrm{Ar}, \mathrm{CO}_{2}$ \\
\hline Industrial inorganic chemicals, NEC & 2819 & 3 & Lithium/alkali metals; uranium; desiccants; tin compounds NEC \\
\hline Petroleum and petroleum products & 2911 & 180 & - \\
\hline Ready-mix concrete & 3273 & 9 & - \\
\hline Cold-rolled steel sheet, strip and bars & 3316 & 75 & - \\
\hline Primary smelting and refining of nonferrous metals except $\mathrm{Cu}$ and $\mathrm{Al}$ & 3339 & 20 & $\mathrm{Be}, \mathrm{Sn}, \mathrm{Cr}, \mathrm{Z}, \mathrm{Zr}, \mathrm{Mg}, \mathrm{Ni}, \mathrm{Te}$ \\
\hline Rolling, drawing, and extruding of copper & 3351 & 4 & Copper and alloy tubing; general copper alloys \\
\hline Drawing and insulating of nonferrous wire & 3357 & 839 & c \\
\hline Fabricated metal products & 34 & 1,615 & -9 \\
\hline Fabricated structural metal & 3441 & 217 & Includes expansion joints for structural shapes: iron and steel \\
\hline Fabricated plate work & 3443 & 972 & Boiler shops; columns (fractionating metal plate); pressure vessels \\
\hline Iron and steel forgings & 3462 & 79 & Nuclear power plant forgings, ferrous (not made in rolling mills) \\
\hline Electroplating, plating, polishing, anodizing, and coloring & 3471 & 43 & Buffing; finishing metal products and formed products \\
\hline Fabricated pipe and pipe fittings & 3498 & 93 & Metal piping systems for pulp, paper, and chemical industries \\
\hline Industrial and commercial machinery & 35 & 1,615 & d \\
\hline Conveyors and conveying equipment & 3535 & 74 & Robotic conveyors for general industrial use \\
\hline Overhead traveling cranes, hoists, and monorail systems & 3536 & 44 & - \\
\hline Metal working machinery and equipment & 354 & 774 & $-d$ \\
\hline Pumps and pumping equipment & 3561 & 5 & - \\
\hline Air and gas compressors & 3563 & 354 & $\begin{array}{l}\text { Vacuum pumps (not laboratory); spraying for metals; paints } \\
\text { and chemicals }\end{array}$ \\
\hline $\begin{array}{l}\text { Industrial and commercial fans and blowers and air purification } \\
\text { equipment }\end{array}$ & 3564 & 11 & Air-cleaning systems; air purification and dust collection equipment \\
\hline General industrial machinery and equipment, NEC & 3569 & 82 & $\begin{array}{l}\text { Industrial centrifuges; robots for general industrial use; automatic } \\
\text { fire sprinkler systems }\end{array}$ \\
\hline Electronic computers & 3571 & 107 & - \\
\hline $\begin{array}{l}\text { Air-conditioning and warm air heating equipment and commercial } \\
\text { and industrial refrigeration equipment }\end{array}$ & 3585 & 27 & $\begin{array}{l}\text { Air-conditioning and heating combination units; (de)humidifiers } \\
\text { (not portable) }\end{array}$ \\
\hline Service industry machinery, NEC & 3589 & 5 & Industrial water treatment equipment \\
\hline Industrial and commercial machinery and equipment, NEC & 3599 & 8 & Bellows; flexible metal hose and tubing \\
\hline Power, distribution, and specialty transformers & 3612 & 38 & $\begin{array}{l}\text { Voltage regulators; rectifier transformers; electric power } \\
\text { transformers }\end{array}$ \\
\hline Switchgear and switchboard apparatus & 3613 & 76 & Busbar structures; air circuit breakers \\
\hline Motors and generators & 3621 & 8 & Rotary converters; synchronous; diesel/gas generator sets \\
\hline
\end{tabular}


TABLE 7 (Cont.)

\begin{tabular}{|c|c|c|c|}
\hline Sector & $\begin{array}{c}\text { SIC/BEA } \\
\text { Code }^{\mathrm{a}} \\
\end{array}$ & Total Cost $t^{b}$ & Keyword/Detailed Description \\
\hline Electric industrial apparatus, NEC & 3629 & 298 & $\begin{array}{l}\text { Condensers (fixed and variables); inverters (nonrotating); AC-DC } \\
\text { convertors (static); rectifiers }\end{array}$ \\
\hline Electronic components, NEC & 3679 & 190 & $\begin{array}{l}\text { Microwave components; waveguides and fittings; power supplies } \\
\text { (static and variable frequencies) }\end{array}$ \\
\hline Electric machinery, equipment and supplies, NEC & 3699 & 1,743 & $\begin{array}{l}\text { Magnetic, pulse, and maser amplifiers; particle accelerators } \\
\text { (including HV); waveguides; betatrons; laser welding, etc. }\end{array}$ \\
\hline $\begin{array}{l}\text { Industrial instruments for measurement, display, and control of } \\
\text { process variables and related products }\end{array}$ & 3823 & 51 & $\begin{array}{l}\text { Computer interface equipment for industrial process control; } \\
\text { industrial data loggers; nuclear reactor controls; telemetering } \\
\text { instruments (industrial process type) }\end{array}$ \\
\hline Laboratory analytical instruments & 3826 & 6 & $\begin{array}{l}\text { Gas chromatographic and infrared instruments; nuclear activation } \\
\text { analysis; spectrophotometers }\end{array}$ \\
\hline Measuring and controlling devices, NEC & 3829 & 65 & Nuclear instrument monitors; nuclear radiation and monitoring \\
\hline Electric services & 4911 & 630 & - \\
\hline Water supply & 4941 & 135 & - \\
\hline Sanitary services & 495 & 54 & Sewerage refuse and systems (including hazardous) ${ }^{d}$ \\
\hline Refuse systems & 4953 & 1,000 & Disposal of radioactive waste materials \\
\hline Computer-integrated system design & 7373 & 107 & - \\
\hline Engineering services & 8711 & 5 & Electrical, industrial, civil, mechanical, petroleum, marine, design \\
\hline Architectural services & 8712 & 1,425 & Architectural engineering services (for profit) \\
\hline Noncommercial research organizations & 8733 & 4,225 & Scientific research, noncommercial \\
\hline Testing laboratories & 8734 & 38 & $\begin{array}{l}\text { Metallurgical, } X \text { ray, radiographing, hydrostatic, calibration, } \\
\text { radiation dosimetry, and pollution testing }\end{array}$ \\
\hline New construction & BEA 11 & 12 & d \\
\hline Industrial buildings & BEA 11.0201 & 728 & - \\
\hline Office buildings & BEA 11.0202 & 46 & - \\
\hline Warehouses & BEA 11.0203 & 15 & - \\
\hline Electric utility facilities & BEA 11.0303 & 50 & - \\
\hline Water supply facilities & BEA 11.0306 & 12 & - \\
\hline Sewer facilities & BEA 11.0307 & 12 & - \\
\hline Total expenditures assigned to sectors & & 19,640 & - \\
\hline
\end{tabular}

a SIC codes are from the 1987 Standard Industrial Classification Manual. BEA accounts are from the 1982 Benchmark Input-Output Accounts of the United States.

b Costs are given in millions of 1994 dollars.

c NEC $=$ not elsewhere classified.

d Assignment of certain expenditures could not be made at a greater level of detail due to insufficient cost information.

c $100 \%$ of SIC code 3357 is superconducting cable. Primary metal is a Nb/Sn alloy that is $100 \%$ imported. 


\section{ESTIMATED NATIONAL AND LOCAL/REGIONAL ECONOMIC IMPACTS}

This section describes the analysis results at the national level and then at the local/regional level. These analyses were performed with the economic models described in Section 3 and the assumptions and reference data delineated in Section 4. A comparison of national-level results for the five analysis cases defined in Section 4 is also presented.

\subsection{NATIONAL ECONOMIC ANALYSIS}

The national economic analysis used two models (LIFT and AMIGA) to compare the national economy with and without ITER. The analysis was limited to annual impacts that would occur during each year of the 30-year ITER life cycle. Changes in GDP, employment, net exports, and disposable income were estimated. Careful scrutiny of LIFT and AMIGA model results for GDP, total employment, employment by sector, net exports, disposable income, and other variables not given in this report demonstrated that the results were consistent between the models. As noted in Section 3.3, ITER is a small expenditure compared with the federal budget and the U.S. economy. Thus, models of the U.S. economy are near their limits in being able to estimate the impact of ITER on the national economy. The study team found that both models were capable of estimating the impacts of ITER. The consistency between the models' results and prior expectations validates the analytical results.

Several factors influence the way in which ITER would affect the national economy. As discussed in Section 4, the most important factors are the cost-sharing assumptions, which determine the level of expenditures in the host and non-host countries, and the source of ITER funds within the U.S. economy. To address these factors explicitly, a set of analysis cases was defined in Section 4.5. The following sections discuss the national economic impacts under each of these analysis cases: reference, S\&T budget realignment, supplemental budget, increased non-host participation, and magnet option.

\subsubsection{Reference Case}

In the reference case, it was assumed that the source of ITER funds would be the federal nondefense budget. Specifically, ITER spending was assumed to alter the composition, but not the total level, of nondefense federal government purchases. That is, federal expenditures on ITER would come from a realignment of the nondefense portion of the federal budget. As shown in Figure 13 for the case when the U.S. is the host Party, peak ITER expenditures would require only about $0.40 \%$ of the 1993 nondefense budget of $\$ 140$ billion. If the U.S. were not the host, peak-year budget requirements would be approximately $35 \%$ less. 
1993 Total Federal Government

Expenditures: $\$ 1,496$ billion

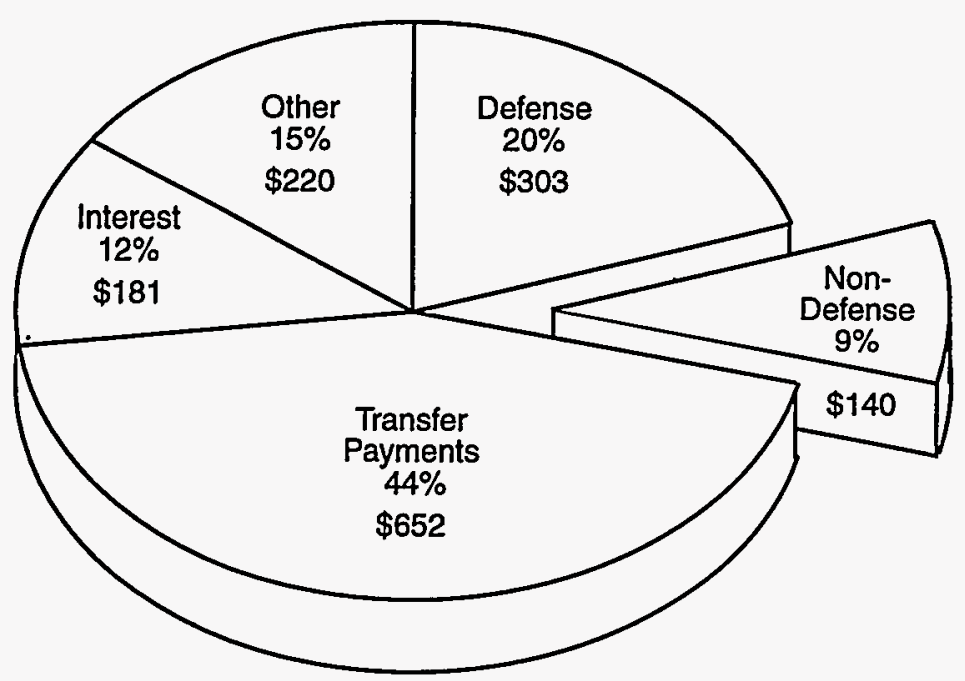

ITER Peak Year

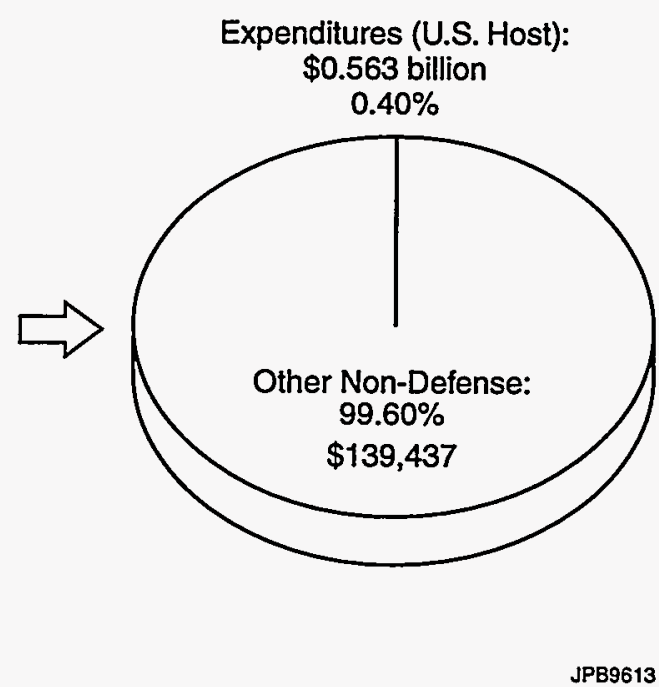

FIGURE 13 ITER Expenditures Relative to Total Federal Government Expenditures: Reference Case (in billions of dollars)

Table 4 and Figures 9, 10, and 11 summarize the host/non-host funding assumptions for the reference case. When the assumptions listed in Table 4 are applied to the economic sector mapping information provided in Table 7, host and non-host spending by sector, as well as host and non-host spending in the host country, can be determined. The pattern of direct spending in the U.S., by economic sector, when the U.S. is the host Party for ITER is displayed in Table 8. Both host and non-host expenditures are shown for the three life-cycle phases. The 54 economic sectors identified in Table 7 are aggregated into 38 sectors in Table 8, including host/non-host labor categories.

As shown in Table 8, the largest spending category during the construction phase is host labor, which peaks at $\$ 281.2$ million during the third and fourth years of construction. Total host labor costs and host expenditures during the 8-year construction period are approximately $\$ 1.8$ billion and $\$ 3.4$ billion, respectively. Throughout the 18 -year operation phase, expenditures for host labor are constant at approximately $\$ 58$ million per year. Non-host labor is the next largest spending category at $\$ 57$ million per year. Non-host spending peaks in the second to last year of the construction phase at $\$ 130.8$ million, when preparation for operation is under way. For the 30-year period, non-host labor costs in the U.S. are approximately $\$ 1.87$ billion (actual spending), and host labor costs are approximately $\$ 3.44$ billion. Non-host expenditures for material purchases in the host country during the operation phase total $\$ 216$ million, which results in a total non-host expenditure of approximately $\$ 2.08$ billion in the host country. As indicated in Table 8 , total expenditures (host and non-host) in the host country are $\$ 10.07$ billion. 
TABLE 8 Life-Cycle Direct Spending in the U.S. by Sector: Reference Case

\begin{tabular}{|c|c|c|c|c|c|c|c|c|c|c|c|c|c|c|}
\hline \multirow[b]{2}{*}{ Secior } & \multirow[b]{2}{*}{ SIC/BEA Code ${ }^{b}$} & \multicolumn{8}{|c|}{ Construction $\operatorname{Cos} 1 \mathrm{~s}^{\mathrm{a}}$} & \multicolumn{2}{|c|}{$\begin{array}{c}\text { Operating } \\
\text { Costs }^{\mathrm{a}}\end{array}$} & \multicolumn{2}{|c|}{$\begin{array}{c}\text { Decommissioning } \\
\text { Costs }^{\mathbf{2}}\end{array}$} & \multirow{2}{*}{$\begin{array}{l}\text { Total } \\
\text { Cost }^{\mathrm{a}} \\
\end{array}$} \\
\hline & & 1999 & 2000 & 2001 & 2002 & 2003 & 2004 & 2005 & 2006 & 2007 & $2007 \cdot 2024$ & 2025 & $2025 \cdot 2028$ & \\
\hline New industrial and commercial buildings & 1796,1799 & 13.96 & 41.87 & 55.83 & 55.83 & 41.87 & 27.91 & 27.91 & 13.96 & 0.00 & 0.00 & 0.00 & 0.00 & 279 \\
\hline New utility structures & BEA $11(303,306)$ & 0.88 & 2.65 & 3.54 & 3.54 & 2.65 & 1.77 & 1.77 & 0.88 & 0.00 & 0.00 & 0.00 & 0.00 & 18 \\
\hline Chemicals and allied products & 28 & 0.04 & 0.11 & 0.15 & 0.15 & 0.11 & 0.08 & 0.08 & 0.04 & 14.59 & 262.62 & 0.00 & 0.00 & 263 \\
\hline $\begin{array}{l}\text { Petroleum refining } \\
\text { Pans }\end{array}$ & 291 & 0.00 & 0.00 & 0.00 & 0.00 & 0.00 & 0.00 & 0.00 & 0.00 & 10.06 & 181.08 & 0.00 & 0.00 & 181 \\
\hline Ready-mix concrete & 3273 & 0.11 & 0.34 & 0.45 & 0.45 & 0.34 & 0.23 & 0.23 & 0.11 & 0.00 & 0.00 & 0.00 & 0.00 & 2 \\
\hline Cold finishing of steel shapes & 3316 & 1.92 & 5.77 & 7.70 & 7.70 & 5.77 & 3.85 & 3.85 & 1.92 & 0.00 & 0.00 & 0.00 & 0.00 & 38 \\
\hline Primary nonferrous metals, NEC ${ }^{\complement}$ & 3339 & 0.26 & 0.78 & 1.05 & 1.05 & 0.78 & 0.52 & 0.52 & 0.26 & 0.00 & 0.00 & 0.00 & 0.00 & 5 \\
\hline Copper rolling and drawing & 3351 & 0.05 & 0.16 & 0.21 & 0.21 & 0.16 & 0.10 & 0.10 & 0.05 & 0.00 & 0.00 & 0.00 & 0.00 & 1 \\
\hline Nonferrous wire drawing and insulating & 3357 & 10.96 & 32.88 & 43.82 & 43.82 & 32.88 & 21.92 & 21.92 & 10.96 & 0.00 & 0.00 & 0.00 & 0.00 & 219 \\
\hline Fabricated structural metal & 3441 & 2.20 & 6.61 & 8.81 & 8.81 & 6.61 & 4.41 & 4.41 & 2.20 & 3.67 & 66.07 & 0.00 & 0.00 & 110 \\
\hline Fabricated plate work & 3443 & 9.84 & 29.51 & 39.35 & 39.35 & 29.51 & 19.68 & 19.68 & 9.84 & 16.39 & 294.96 & 0.00 & 0.00 & 492 \\
\hline Iron and steel forging & 3462 & 0.80 & 2.39 & 3.18 & 3.18 & 2.39 & 1.59 & 1.59 & 0.80 & 1.33 & 23.87 & 0.00 & 0.00 & 40 \\
\hline Plating and polishing & 3471 & 0.44 & 1.32 & 1.76 & 1.76 & 1.32 & 0.88 & 0.88 & 0.44 & 0.73 & 13.21 & 0.00 & 0.00 & 22 \\
\hline Pjpe, valves, and pipe fittings & 3498 & 0.94 & 2.81 & 3.75 & 3.75 & 2.81 & 1.88 & 1.88 & 0.94 & 1.56 & 28.13 & 0.00 & 0.00 & 47 \\
\hline Conveyors and conveying equipment & 3535 & 0.85 & 2.24 & 2.94 & 2.94 & 2.24 & 3.62 & 3.97 & 3.27 & 1.93 & 34.79 & 0.00 & 0.00 & 57 \\
\hline Hoists, cranes, and monorails & 3536 & 0.51 & 1.33 & 1.74 & 1.74 & 1.33 & 2.15 & 2.35 & 1.94 & 1.15 & 20.66 & 0.00 & 0.00 & 34 \\
\hline Machinery and equipment & 354 & 10.09 & 30.27 & 40.37 & 40.37 & 30.27 & 20.18 & 20.18 & 10.09 & 2.37 & 42.66 & 0.00 & 0.00 & 244 \\
\hline Pumps and compressors & 3561,3563 & 4.14 & 10.87 & 14.24 & 14.24 & 10.87 & 17.56 & 19.24 & 15.88 & 9.38 & 168.79 & 0.00 & 0.00 & 276 \\
\hline Blowers and fans & 3564 & 0.13 & 0.33 & 0.44 & 0.44 & 0.33 & 0.54 & 0.59 & 0.49 & 0.29 & 5.16 & 0.00 & 0.00 & 8 \\
\hline General industrial machinery, NEC & 3569 & 0.95 & 2.49 & 3.26 & 3.26 & 2.49 & 4.02 & 4.40 & 3.63 & 2.14 & 38.60 & 0.00 & 0.00 & 63 \\
\hline Electronic computers & 3571 & 2.59 & 5.27 & 6.61 & 6.61 & 5.27 & 20.13 & 22.83 & 21.49 & 19.84 & 357.12 & 0.00 & 0.00 & 448 \\
\hline Refrigeration and heating equipment & 3585 & 0.31 & 0.93 & 1.24 & 1.24 & 0.93 & 0.62 & 0.62 & 0.31 & 2.00 & 36.01 & 0.00 & 0.00 & 42 \\
\hline Service industry machines, NEC & 3589 & 0.06 & 0.17 & 0.23 & 0.23 & 0.17 & 0.12 & 0.12 & 0.06 & 0.37 & 6.65 & 0.00 & 0.00 & 8 \\
\hline Industrial machines, NEC & 3599 & 0.10 & 0.27 & 0.35 & 0.35 & 0.27 & 0.41 & 0.45 & 0.37 & 0.21 & 3.81 & 0.00 & 0.00 & 6 \\
\hline Transformers & 3612 & 0.22 & 0.67 & 0.89 & 0.89 & 0.67 & 0.45 & 0.45 & 0.22 & 0.00 & 0.00 & 0.00 & 0.00 & 4 \\
\hline Switchgear and switchboard apparatus & 3613 & 0.45 & 1.34 & 1.79 & 1.79 & 1.34 & 0.90 & 0.90 & 0.45 & 0.00 & 0.00 & 0.00 & 0.00 & 9 \\
\hline Motors and generators & 3621 & 0.05 & 0.14 & 0.19 & 0.19 & 0.14 & 0.09 & 0.09 & 0.05 & 0.00 & 0.00 & 0.00 & 0.00 & 1 \\
\hline Electric industrial apparatus, NEC & 3629 & 1.75 & 5.26 & 7.02 & 7.02 & 5.26 & 3.51 & 3.51 & 1.75 & 0.00 & 0.00 & 0.00 & 0.00 & 35 \\
\hline Electronic components, NEC & 3679 & 2.21 & 6.65 & 8.87 & 8.87 & 6.65 & 4.44 & 4.44 & 2.21 & 0.00 & 0.00 & 0.00 & 0.00 & 44 \\
\hline Electric equipment, NEC & 3699 & 2.76 & 3.28 & 3.54 & 3.54 & 3.28 & 24.62 & 28.22 & 27.96 & 20.00 & 360.00 & 0.00 & 0.00 & 457 \\
\hline Mechanical measuring devices & 3823,3829 & 1.53 & 4.59 & 6.13 & 6.13 & 4.59 & 3.07 & 3.07 & 1.53 & 0.00 & 0.00 & 0.00 & 0.00 & 31 \\
\hline Electric services & 4911 & 0.00 & 0.00 & 0.00 & 0.00 & 0.00 & 0.00 & 0.00 & 0.00 & 35.20 & 633.60 & 0.00 & 0.00 & 634 \\
\hline Water supply and sewerage services & 4941 & 1.16 & 3.50 & 4,66 & 4.66 & 3.50 & 2.34 & 2.34 & 1.16 & 1.20 & 21.57 & 100.00 & 400.00 & 445 \\
\hline Sanitary services and steam supply & 495,4953 & 0.00 & 0.00 & 0.00 & 0.00 & 0.00 & 0.00 & 0.00 & 0.00 & 9.36 & 168.51 & 0.00 & 0.00 & 169 \\
\hline Engineering and architectural services & 8711,8712 & 0.47 & 1.42 & 1.89 & 1.89 & 1.42 & 0.94 & 0.94 & 0.47 & 0.00 & 0.00 & 0.00 & 0.00 & 9 \\
\hline Research, development, and testing services & 8733,8734 & 1.41 & 4.24 & 5.65 & 5.65 & 4.24 & 2.82 & 2.82 & 1.41 & 0.00 & 0.00 & 0.00 & 0.00 & 28 \\
\hline Federal government nonmilitary & Host Jabor & 120.45 & 227.60 & 281.18 & 281.18 & 227.60 & 228.02 & 237.02 & 183.45 & 58.24 & $1,048.32$ & 150.00 & 600.00 & 3,435 \\
\hline Non-host labor ${ }^{d}$ & Non-host labor & 58.74 & 94.29 & 112.06 & 112.06 & 94.29 & 123.09 & 130.85 & 113.08 & 57.13 & $1,028.38$ & 0.00 & 0.00 & 1,867 \\
\hline Total & & 253.33 & 534.36 & 674.90 & 674.90 & 534.36 & 548.46 & 574.22 & 433.67 & 269.14 & $4,844.56$ & 250.00 & $1,000.00$ & 10,073 \\
\hline
\end{tabular}

- Costs are given in millions of 1994 dollars.

b SIC codes are from the 1987 Standard Industrial Classification Manual. BEA accounts are from the 1982 Benchmark Input-Output Accounts of the United States.

c $\mathrm{NEC}=$ not elsewhere classified.

d Non-host labor expenditures are calculated by adjusting "total non-host labor costs at site" as follows: (i) five-sixths of the labor cost pays for the scientists/engineers located at the host site, and one-sixth pays for support at the home institution; and (2) of the labor payments made to the scientists/engineers at the host site, only $69 \%$ is actually spent at the site; the remaining $31 \%$ is allowed for taxes, pension contributions, and other payments made in home countries. 
Spending in non-labor sectors is led by electric services, followed by fabricated plate work, other electric equipment, electronic computers, and water supply and sewerage services (which includes disposal of all ITER waste). Water supply and sewerage systems are used primarily in the decommissioning phase. The other large sectors are construction, chemicals, and other types of equipment. As shown in Table 8, total direct spending on ITER peaks in the third and fourth years of construction at nearly $\$ .675$ million.

Figure 14 compares the host/non-host budgetary requirements for the reference case. Federal outlays over the entire project fall from $\$ 7.99$ billion when the U.S. is the host to $\$ 3.88$ billion when the U.S. is a full-share, non-host participant. This contrast between hosting and non-hosting is approximately the same for all cases. As Figure 14 indicates, the full impact of ITER on the U.S. economy is due to all expenditures in the U.S., whether they are from the federal budget or other sources. Total reference case expenditures in the U.S. for the host/non-host cases are shown in the second and fourth columns in Figure 14. If the U.S. were host, total expenditures in the U.S. would be $\$ 10.07$ billion, of which $\$ 7.99$ billion would come from the federal budget. If the U.S. were a full-share, non-host participant in ITER, total expenditures in the U.S. would be $\$ 3.19$ billion, although the total allocation from the federal budget would amount to $\$ 3.88$ billion. This situation occurs because U.S. scientists and engineers would spend considerable time and money (estimated at $\$ 0.69$ billion) at a host site outside the U.S. Expenditures made elsewhere do not provide shortterm benefits to the U.S. economy.

The national analysis in the reference case when the U.S. is host centers around estimating the change in the economy due to reallocating of $\$ 7.99$ billion of federal budget expenditures (Figure 14, column 1) plus adding $\$ 2.08$ billion of non-host expenditures in the U.S. over 30 years (Figure 14, column 2).

The net impact on GDP in the reference case is a very small increase, that is, on the order of $\$ 100$ million annually. This impact on GDP may appear to be small relative to the size of the annual expenditures on ITER in the U.S. shown in Table 8; however, a slight negative change in GDP would be expected from the realignment of the $\$ 7.99$ billion within the federal budget. Thus, the increase in GDP measured by the models is due to the $\$ 2.08$ billion in non-host expenditures in the U.S. over the life of the project. Within this context, the small positive impact on GDP shown in both models is plausible.

The situation when the U.S. is a full-share, non-host participant in ITER is summarized in columns 3 and 4 in Figure 14. While federal expenditures total $\$ 3.88$ billion, federal (and non-host) expenditures in the U.S. amount to only $\$ 3.19$ billion because $\$ 0.69$ billion leaves the U.S. as scientists and engineers participate in ITER and spend money at the host site outside the U.S. The impact on GDP is a decline of approximately $\$ 100$ million annually. 


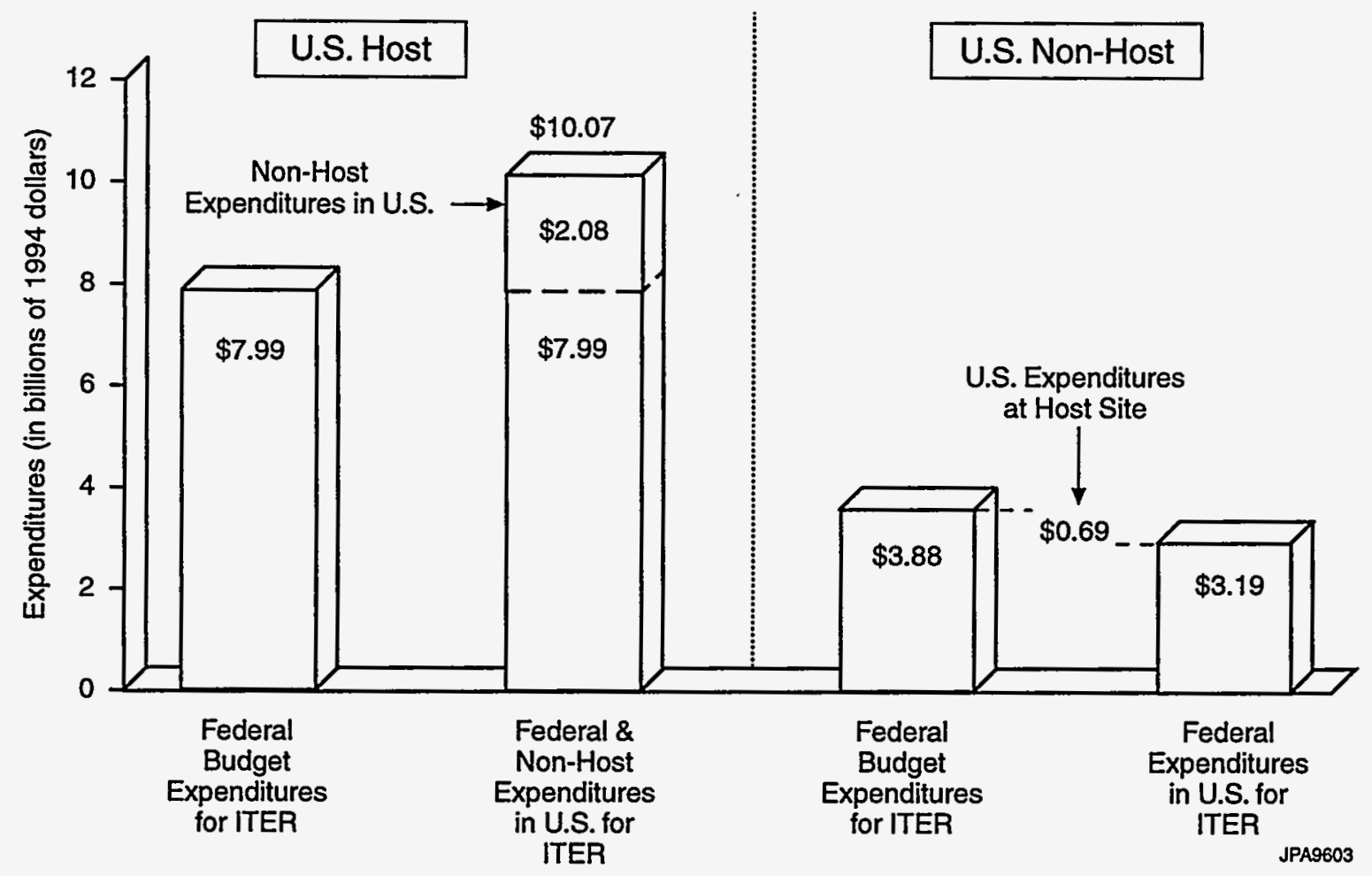

FIGURE 14 Comparison of U.S. Host and Non-Host Expenditures: Reference Case

Employment effects for the U.S. host reference case are similar to the GDP effects: positive, but extremely small. Results indicate an approximate net gain of 1,000 jobs during the construction phase, followed by a smaller annual net increase during the operation phase. These gains occur within the context of a projected overall U.S. employment level of 136 million workers at the beginning of the project.

An expected finding is that the shifting of federal funds to ITER leads to a decline in employment in sectors that lose funding and an increase in sectors that have more activity as a consequence of ITER. The net gains would be larger, except for the assumption that all ITER labor, because of the higher levels of skill required, has an average cost of $\$ 75,000$ per worker. This cost is significantly higher than the federal employment labor rate average and results in fewer direct jobs created per dollar spent.

The issue of ITER labor rates has a further implication. Specifically, without non-host spending in the U.S., the net employment impacts would have been negative in the reference case. If the only consequence of ITER were to shift funds from one configuration of federal spending to another, the configuration with the lowest average labor rate would have the greatest total employment. As noted earlier, ITER has a distinctly higher labor rate because of the mix of skills required. 
An example of the diversity of net employment impacts within the economy is shown in Figure 15. Relative to the situation without ITER, some sectors gain employment and others lose employment. Figure 15 provides examples of both cases.

The trade balance impacts of ITER in the U.S. host reference case are also small and positive, as summarized in Table 9 . Analysis results indicate that the reallocation of federal budget expenditures for ITER increases net imports. This outcome is a result of an expenditure stream for ITER that requires more equipment and materials than the average federal budget expenditure. On average, the U.S. economy imports more products in the equipment and material areas than in the various service areas that are more typical of federal expenditures. A net improvement in the trade balance occurs, however, because of the export effect of the purchases of visiting ITER workers in the U.S. The life-cycle improvement in the balance of trade in the reference case is $\$ 275$ million. As in the case of employment, the impact of ITER on trade balance would have been slightly negative without international participation.

The maximum increase in net exports in the reference case is $\$ 111$ million per year during the construction phase. For the supplemental budget case, the peak increase in net exports is $\$ 75$ million and may even be negative, depending on assumptions regarding the impact of increased expenditures on wages in a full employment economy. Upward pressure on wages increases the prices of U.S. goods and services, which reduces U.S. exports.

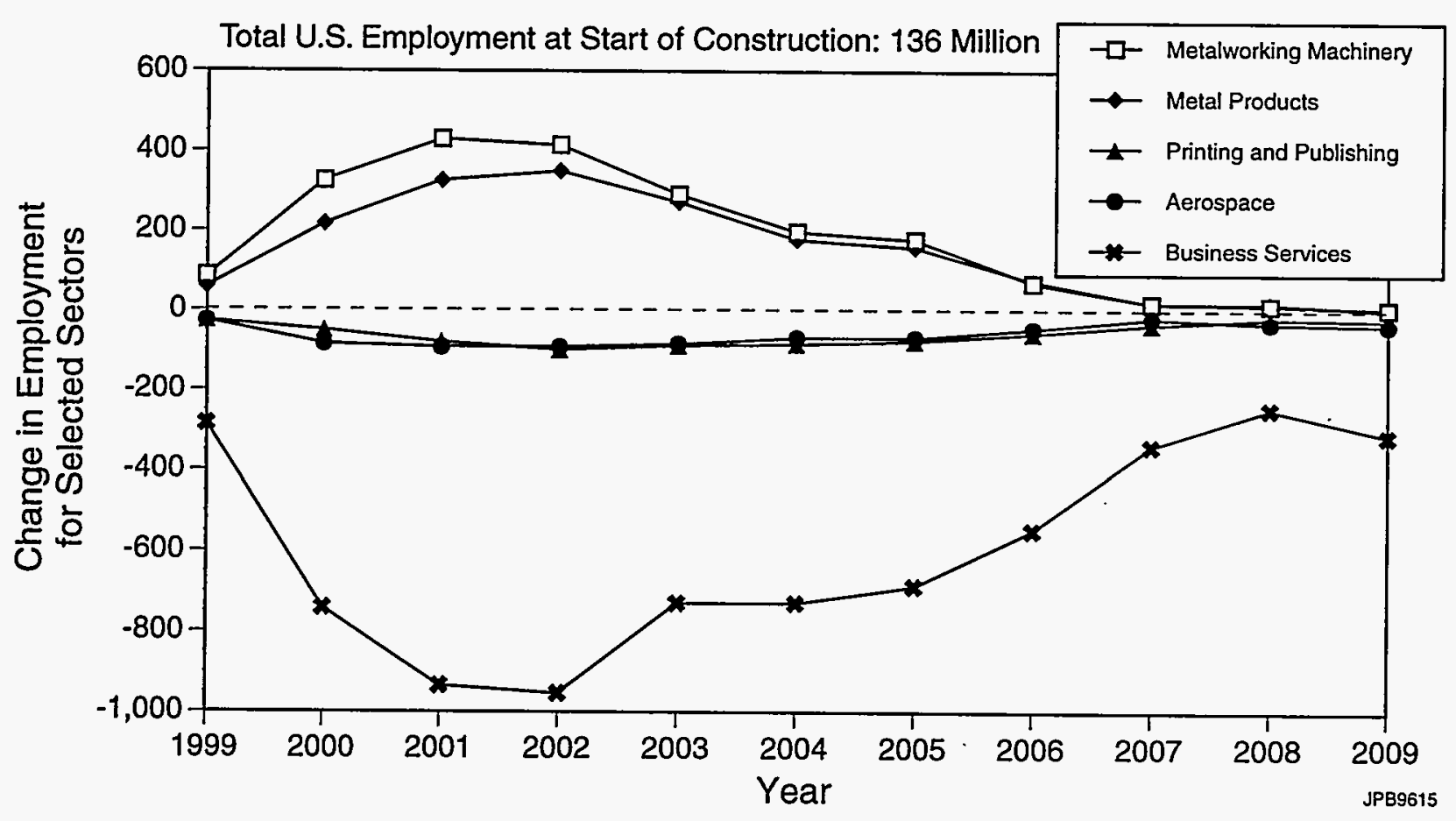

FIGURE 15 Annual ITER Sectoral Employment Impacts: Reference Case 
TABLE 9 U.S. Host Trade Balance Impacts: Reference Case (in millions of 1994 dollars)

\begin{tabular}{lccc}
\hline & \multicolumn{3}{c}{ Impact } \\
\cline { 2 - 4 } \multicolumn{1}{c}{ Impact Category } & $\begin{array}{c}\text { Construction } \\
\text { Year Average }\end{array}$ & $\begin{array}{c}\text { Operating } \\
\text { Year Average }\end{array}$ & $\begin{array}{c}\text { Life-Cycle } \\
\text { Total }\end{array}$ \\
\hline Change in imports & 60 & 37 & 1,137 \\
Change in exports & -30 & -19 & -585 \\
$\begin{array}{lccc}\text { Export to visiting workers } \\
\text { in the U.S. }\end{array}$ & 105 & 64 & 1,997 \\
Net trade balance change & 15 & 8 & 275 \\
\hline
\end{tabular}

The impact on disposable income in the U.S. host reference case is similar to impacts on GDP, employment, and trade: a very small positive impact. The reference case shows an almost imperceptible decline in most years, while in other years, it shows an increase of up to $\$ 0.39$ per capita per year. In the supplemental budget case, disposable income is higher in each year, peaking at $\$ 1.79$ per capita per year.

The life-cycle fiscal implication of ITER is a positive and substantial increase in federal revenues relative to the overall size of the ITER expenditure. If the U.S. were host:

- U.S. ITER expenditures would be $\$ 7.99$ billion.

- U.S. GDP would increase $\$ 2.8$ billion.

- U.S. federal revenues would increase $\$ 1.0$ billion.

If the U.S. were a full-share, non-host participant, federal revenues would experience a small decline over the project life:

- U.S. ITER expenditures would be $\$ 3.88$ billion.

- U.S. GDP would decrease \$1.9 billion.

- U.S. federal revenues would decrease $\$ 0.6$ billion. 
Because of the federal revenue implications, the difference in federal revenues needed between the host and non-host cases is $\$ 2.51$ billion. This amount is calculated as the difference between the $\$ 7.99$ billion expenditure from the federal budget minus $\$ 1$ billion of additional tax revenues in the host case and the $\$ 3.88$ billion expenditure plus $\$ 0.6$ billion of lost revenues in the non-host case. The question raised by this comparison is whether the additional cost of hosting ITER is worth the additional gains in GDP, trade, employment, and disposable income, plus other broader implications not evaluated in this study.

\subsubsection{S\&T Budget Realignment Case}

The S\&T budget realignment case is identical to the reference case in all respects except for the source of federal funds. In the reference case, funds are taken proportionally from all sectors of the U.S. economy that receive federal nondefense expenditures. In the S\&T budget realignment case, however, ITER expenditures are taken only from nondefense S\&T funds. The results of the analysis showed only extremely slight declines from the modest positive impact for the reference case.

Although the overall short-term economic impacts of funding ITER from S\&T funds would be virtually indistinguishable from those of funding from the overall nondefense budget, the longterm impacts of reallocating S\&T funds were not analyzed. Such a study would require consideration of which S\&T budgets would be shifted to ITER and the opportunity costs for spending these funds on ITER. In other words, what S\&T activities would have to be forgone and what benefit streams would result from that work? The long-term implications are difficult to ascertain but could be important.

Because of the similarity between the reference case and the S\&T budget realignment case in terms of GDP and employment, the trade and disposable income results are not discussed here. In the U.S. non-host case, the results were essentially the same as in the reference non-host case.

\subsubsection{Supplemental Budget Case}

The distinguishing feature of the supplemental budget case relative to the reference case is that the U.S. share of ITER is paid by additional federal expenditures. No existing federal expenditures would be altered. Because additional taxation by the federal government was not considered, the source of funds would be further borrowing. The economy would feel an immediate stimulus, but the impact of debt repayment would be deferred and was not analyzed. Thus, this case evaluates the short-term effects of shifting the federal budget compared with leaving expenditures intact and adding to the budget. 
The annual increase in GDP in the supplemental budget case is on the order of $\$ 1$ billion during the construction period and declines to an annual increase of about $\$ 500$ million during operation. This large change, relative to the reference case, is directly attributable to the increased level of federal expenditures. The increase in GDP peaks at more than $\$ 1.2$ billion during the fifth year of construction.

The impact on employment is similar, with an annual net employment increase that peaks at more than 8,000 jobs. After the transition from construction to operation, ITER employment gains would stabilize at about 2,000 jobs.

The consequences for sectoral employment differ considerably from those of the reference case, although they are still small relative to total employment. As noted in Figure 15, for example, some sectors undergo net gains, while others sustain losses under the reference case. When the same example sectors are considered in the supplemental budget case, all sectors experience some gain, as shown in Figure 16. Business services, which lost the most jobs in the reference case (Figure 15), now gain the greatest number.

Both models revealed less favorable international trade results for ITER in the supplemental budget case. This decline in the trade balance relative to the reference case is due to a small increase in U.S. prices and higher GDP associated with the increased economic activity in the supplemental budget case.

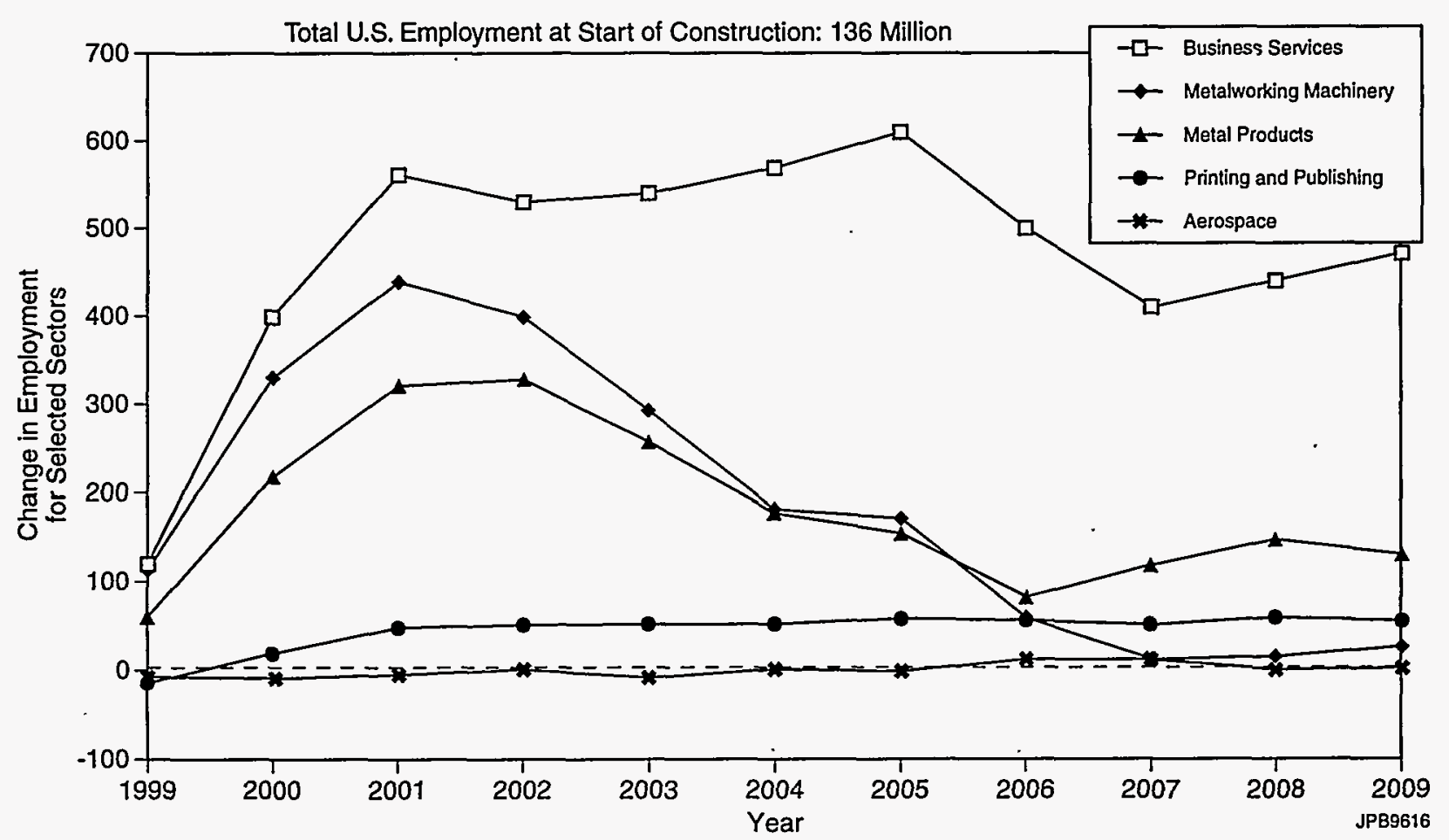

FIGURE 16 Annual ITER Sectoral Employment Impacts: Supplemental Budget Case 
Some increase in prices is expected within the context of the full employment economy assumed by both models. As U.S. prices increase, the U.S. trade balance decreases as some U.S. goods and services are priced out of foreign markets. The greater GDP in the supplemental budget case also increases imports.

In one model, the gain in imports and loss of exports are sufficient to push the trade balance in a negative direction for the supplemental budget case. However, after considerable scrutiny of the trade balance results, the finding is that the results of the LIFT and AMIGA models are quite close, well within the range of plausible trade consequences, and are consistent in predicting a relative decline in the trade balance in the supplemental budget case.

\subsubsection{Increased Non-Host Participation Case}

The key assumptions for the increased non-host participation case were described in Section 4.5 and summarized in Table 5. The reference and increased non-host participation cases are virtually indistinguishable in terms of their impact on the national economy.

\subsubsection{Magnet Option Case}

The results for the magnet option case are also indistinguishable from the reference case results at the national level. Important reasons for considering this case may exist, such as potential long-term economic considerations. However, for national short-run impacts, this case has essentially the same impact as the reference case.

\subsubsection{Comparison of Study Cases}

Figure 17 compares the annual changes in GDP for the five cases when the U.S. hosts ITER with the reference case when the U.S. is a non-host participant. As shown, the supplemental budget case shows the largest annual change in GDP, which reaches more than $\$ 1$ billion during construction and stabilizes at approximately $\$ 500$ million during operation. The four other host cases are essentially the same, with average annual GDP increases of more than $\$ 100$ million. The nonhost reference case shows a decline in GDP of about $\$ 100$ million per year.

The year-to-year variations in GDP in both the host and non-host cases are primarily explained by the year-to-year changes in expenditure patterns, which are shown in Table 8 for the U.S. host case. The greatest increase (or decline in the non-host case) in GDP coincides with the construction phase (1999-2006), which is the period of largest expenditures. 


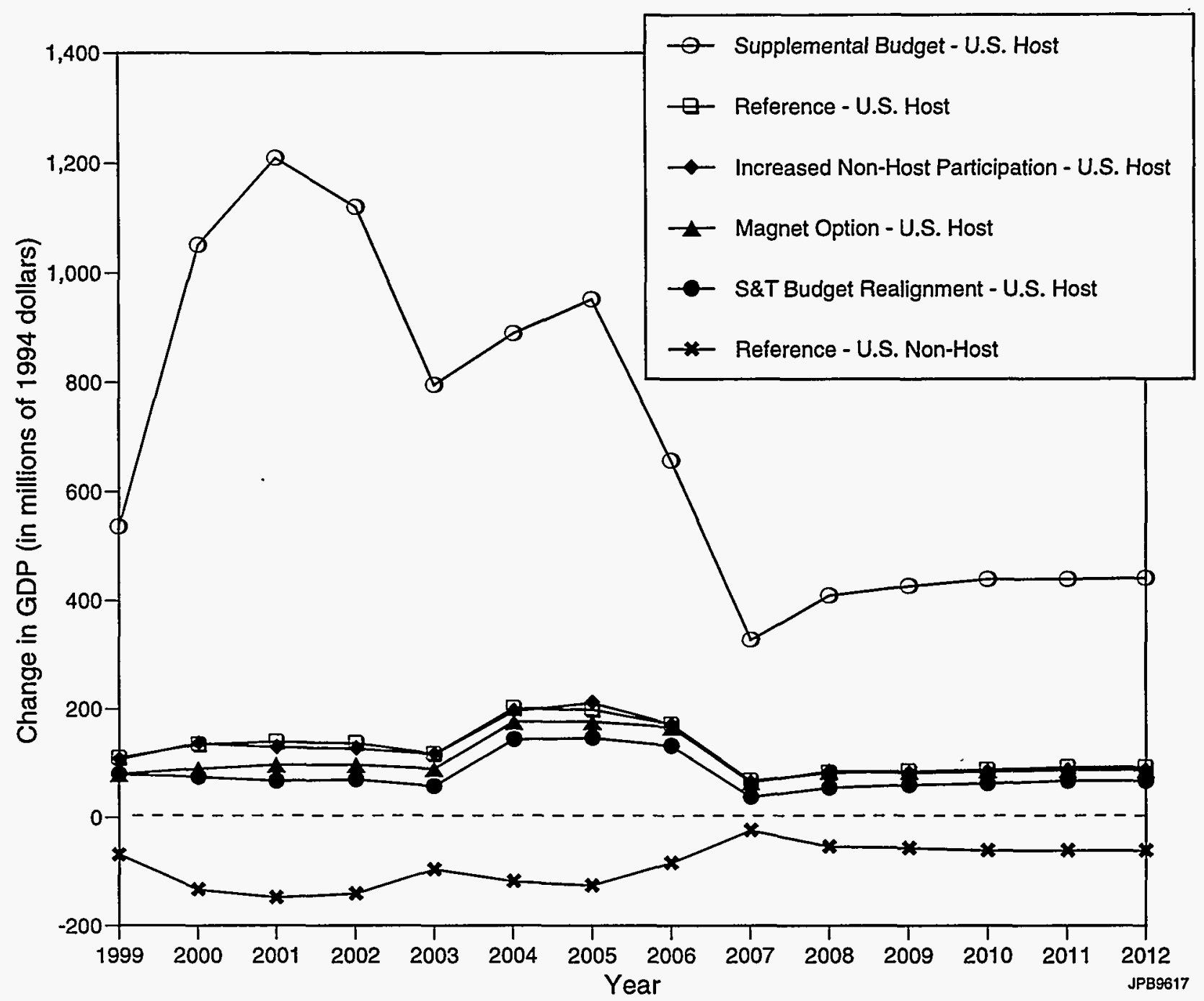

FIGURE 17 Comparison of Changes in GDP for ITER Study Cases

The economic models used in the analysis also consider some lagged responses and cyclic behavior in the economy. Cyclic or short-term oscillating behavior occurs in various economic parameters, such as interest rates, which in turn affect other variables, such as GDP. The impact of lagged effects and cyclic behavior is noticeable, for example, when the ITER project makes an abrupt transition in expenditures from construction to operations in the year 2007. As this transition occurs, an adjustment in the economy appears to temporarily suppress both GDP and employment (Figures 17 and 18), where the net employment change drops to near zero or slightly negative. This response captures such factors as the transition at the end of construction, where direct and indirect jobs are lost in some sectors and suddenly added in others. By the year 2008, the economy has largely adjusted to the transition. 


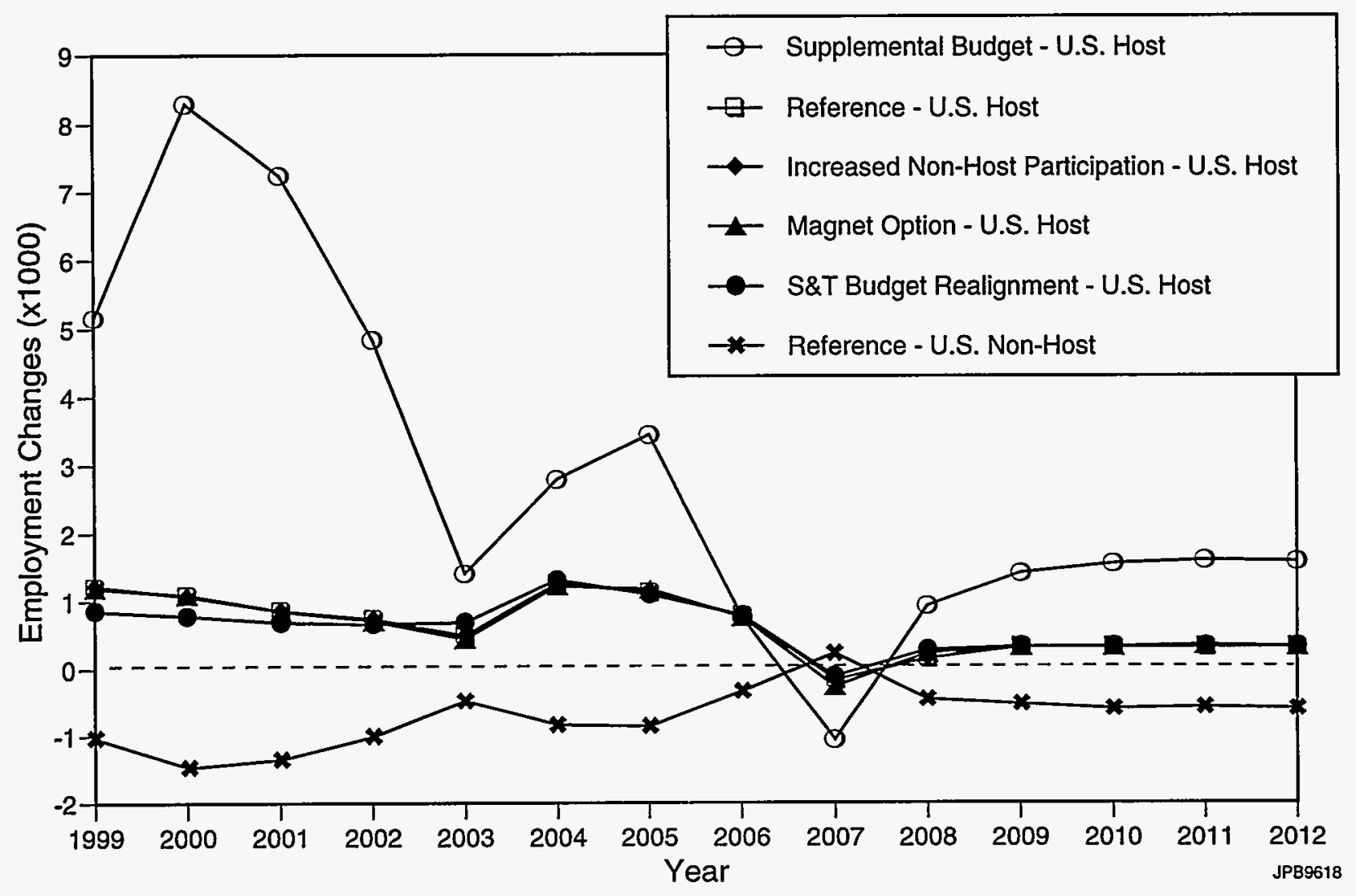

FIGURE 18 Comparison of Changes in Employment for ITER Study Cases

Figure 18 compares aggregate employment changes for the same six cases. Once again, the supplemental budget case leads to the largest employment impacts, with a peak annual net employment increase of more than 8,000 jobs. The other U.S. host cases lead to significantly fewer new jobs. The non-host reference case shows a net loss of jobs because federal funds are being spent outside the U.S.

\subsection{LOCAL/REGIONAL ECONOMIC ANALYSIS}

This section describes the estimated economic benefits that would accrue to the local area that serves as the ITER site in the U.S. Estimates are reported for the changes that are likely to occur in the employment, personal income, and output of a "typical" location. Two analysis cases are examined: the reference case and the increased non-host participation case. The other cases identified in Table 5, which depend on the source of federal funding (i.e., S\&T budget realignment case and supplemental budget case) and reflect small changes in cost sharing (i.e., magnet option case), do not result in significantly different estimated benefits at the local/regional level. 
Total spending in the U.S. by host/non-host participants was assumed to be $\$ 10.073$ billion, as shown in Table 8. Total spending was allocated to various economic sectors, including labor, by using the procedures described in Section 4.6. The life-cycle expenditures by sector shown in Table 8 were used as the primary input data. Only a portion of the total ITER spending in the U.S. will occur at the specific location that serves as the site for ITER. This proportion is likely to vary, depending on the size and sectoral diversification of a specific location.

The portion of total ITER spending that producers in a local area are likely to supply was represented by the local LPC estimated for each spending category for each location. The size of the LPC differed according to the type of good or service. All labor was assumed to be located entirely within the local area, so that all direct labor spending was captured within the study area. For materials and equipment, the proportion of local direct spending was estimated for each sector, depending on whether the sector sells its output in national or local markets.

Some sectors that would provide goods and services to ITER sell in national markets. For these sectors, the analysis assumed that ITER will employ competitive bids and that a local area's share of ITER expenditures in each sector will be equal to the local area's share of the national sectoral output. It was assumed that all equipment manufacturing sectors and some service sectors (engineering and architectural services, $R \& D$ testing laboratories) operate in national markets.

Certain goods and services would be provided primarily by local firms. The LPCs for each sector used in the local/regional analysis are shown in Table 10. The LPCs for construction services (SIC 1796 and 1799) and concrete (SIC 3273) were assumed to be 95\%, corresponding to a relatively small amount of nonlocal supply of these items. Many of these products are low in value and have a relatively large transportation cost component; thus, they are unlikely to be competitive outside the areas in which they are produced. Fifty percent of electricity (SIC 4911) was assumed to be purchased locally. The LPCs were assumed to be $100 \%$ for water supply and sewerage services (SIC 4941) and 50\% for sanitary services (SIC 495 and 4953).

Table 11 shows the direct spending by sector that would be expected in a local/regional area under the reference case. Table 12 shows direct spending by sector under the increased non-host participation case.

Under the reference case, local direct ITER spending would peak at $\$ 412.8$ million in the third year of construction, equal $\$ 143.1$ million per year during operation, and increase to $\$ 250$ million per year during decommissioning. Figure 19 compares direct spending at the national and local levels. Under the increased non-host participation case, construction spending and decommissioning expenditures in the local area would be slightly lower, while operating year expenditures would be identical to those for the reference case. 
TABLE 10 Sector Multipliers and Local Purchase Coefficients

\begin{tabular}{|c|c|c|c|c|c|}
\hline \multirow[b]{2}{*}{ Sector } & \multirow[b]{2}{*}{ SIC/BEA Codes $^{a}$} & \multicolumn{3}{|c|}{ Average Multipliers } & \multirow[b]{2}{*}{ LPCs } \\
\hline & & Output & $\begin{array}{l}\text { Personal } \\
\text { Income }\end{array}$ & Employment & \\
\hline New industrial and commercial buildings & 1796,1799 & 1.687 & 0.532 & 21.264 & 0.950 \\
\hline New utility structures & BEA $11(303,306)$ & 1.726 & 0.393 & 15.684 & 0.950 \\
\hline Chemicals and allied products & 28 & 1.610 & 0.553 & 14.579 & 0.038 \\
\hline Petroleum refining & 291 & 1.020 & 0.049 & 1.151 & 0.041 \\
\hline Ready-mix concrete & 3273 & 1.468 & 0.407 & 14.855 & 0.950 \\
\hline Cold finishing of steel shapes & 3316 & 1.559 & 0.298 & 8.843 & 0.114 \\
\hline Primary nonferrous metals, $N C^{b}$ & 3339 & 1.336 & 0.251 & 6.954 & 0.016 \\
\hline Copper rolling and drawing & 3351 & 1.526 & 0.273 & 10.496 & 0.020 \\
\hline Nonferrous wire drawing and insulating & 3357 & 1.546 & 0.423 & 10.588 & 0.023 \\
\hline Fabricated structural metal & 3441 & 1.554 & 0.469 & 14.946 & 0.013 \\
\hline Fabricated plate work & 3443 & 1.674 & 0.644 & 21.328 & 0.008 \\
\hline Iron and steel forging & 3462 & 1.589 & 0.527 & 15.880 & 0.026 \\
\hline Plating and polishing & 3471 & 1.890 & 0.771 & 27.913 & 0.026 \\
\hline Pipe, valves, and pipe fittings & 3498 & 1.567 & 0.535 & 16.598 & 0.019 \\
\hline Conveyors and conveying equipment & 3535 & 1.561 & 0.492 & 16.133 & 0.018 \\
\hline Hoists, cranes, and monorails & 3536 & 1.576 & 0.444 & 14.077 & 0.051 \\
\hline Machinery and equipment & 354 & 1.641 & 0.662 & 20.337 & 0.023 \\
\hline Pumps and compressors & 3561,3563 & 1.485 & 0.386 & 12.342 & 0.038 \\
\hline Blowers and fans & 3564 & 1.649 & 0.589 & 19.030 & 0.037 \\
\hline General industrial machinery, NEC & 3569 & 1.588 & 0.468 & 15.582 & 0.027 \\
\hline Electronic computers & 3571 & 1.822 & 0.639 & 20.371 & 0.091 \\
\hline Refrigeration and heating equipment & 3585 & 1.653 & 0.423 & 15.126 & 0.006 \\
\hline Service industry machines, NEC & 3589 & 1.450 & 0.440 & 11.976 & 0.040 \\
\hline Industrial machines, NEC & 3599 & 1.722 & 0.667 & 25.410 & 0.022 \\
\hline Transformers & 3612 & 1.721 & 0.609 & 20.271 & 0.017 \\
\hline Switchgear and switchboard apparatus & 3613 & 1.636 & 0.542 & 15.622 & 0.038 \\
\hline Motors and generators & 3621 & 1.728 & 0.572 & 19.629 & 0.032 \\
\hline Electrical industrial apparatus, NEC & 3629 & 1.618 & 0.416 & 14.619 & 0.037 \\
\hline Electronic components, NEC & 3679 & 1.630 & 0.422 & 15.911 & 0.035 \\
\hline Electrical equipment, NEC & 3699 & 1.940 & 0.523 & 19.764 & 0.030 \\
\hline Mechanical measuring devices & 3823,3829 & 1.484 & 0.510 & 15.821 & 0.021 \\
\hline Electric services & 4911 & 1.281 & 0.254 & 7.351 & 0.500 \\
\hline Water supply and sewerage services & 4941 & 2.011 & 0.509 & 20.623 & 1.000 \\
\hline Sanitary services and steam supply & 495,4953 & 1.732 & 0.419 & 14.966 & 0.500 \\
\hline Engineering and architectural services & 8711,8712 & 2.029 & 0.875 & 34.630 & 0.015 \\
\hline Research, development, and testing services & 8733,8734 & 2.007 & 0.767 & 33.193 & 0.017 \\
\hline Federal government non-military & Host labor & 1.662 & 1.222 & 31.919 & 1.000 \\
\hline Non-host labor & Non-host labor & 1.727 & 0.554 & 26.695 & 0.575 \\
\hline
\end{tabular}

a SIC codes are from the 1987 Standard Industrial Classification Manual. BEA accounts are from the 1982 Benchmark Input-Output Accounts of the United States.

b $\mathrm{NEC}=$ not elsewhere classified. 
TABLE 11 Life-Cycle Direct Spending in Local Area by Sector: Reference Case

\begin{tabular}{|c|c|c|c|c|c|c|c|c|c|c|c|c|c|c|c|}
\hline \multirow[b]{2}{*}{ Sector } & \multirow[b]{2}{*}{$\begin{array}{c}\text { SIC/BEA } \\
\text { Coded }^{\mathrm{b}}\end{array}$} & \multirow[b]{2}{*}{ LPC } & \multicolumn{8}{|c|}{ Consiruction Cosis ${ }^{\mathrm{a}}$} & \multicolumn{2}{|c|}{ Operating Costs ${ }^{\mathbf{a}}$} & \multicolumn{2}{|c|}{ Decommissioning Costs ${ }^{\mathrm{a}}$} & \multirow[b]{2}{*}{$\begin{array}{l}\text { Total } \\
\text { Costs }^{\mathrm{a}}\end{array}$} \\
\hline & & & 1999 & 2000 & 2001 & 2002 & 2003 & 2004 & 2005 & 2006 & 2007 & 2007-2024 & 2025 & 2025-2028 & \\
\hline New industrial and commercial buildings & 1796, 1799 & 0.950 & 13.26 & 39.78 & 53.04 & 53.04 & 39.78 & 26.51 & 26.51 & 13.26 & 0.00 & 0.00 & 0.00 & 0.00 & 265.18 \\
\hline New utility structures & BEA $11(303,306)$ & 0.950 & 0.84 & 2.52 & 3.36 & 3.36 & 2.52 & 1.68 & 1.68 & 0.84 & 0.00 & 0.00 & 0.00 & 0.00 & 16.80 \\
\hline Chemicals and allied products & 28 & 0.038 & 0.00 & 0.00 & 0.01 & 0.01 & 0.00 & 0.00 & 0.00 & 0.00 & 0.56 & 10.10 & 0.00 & 0.00 & 10.13 \\
\hline Petroleum refining & 291 & 0.041 & 0.00 & 0.00 & 0.00 & 0.00 & 0.00 & 0.00 & 0.00 & 0.00 & 0.42 & 7.50 & 0.00 & 0.00 & 7.50 \\
\hline Ready-mix concretc & 3273 & 0.950 & 0.10 & 0.32 & 0.43 & 0.43 & 0.32 & 0.22 & 0.22 & 0.10 & 0.00 & 0.00 & 0.00 & 0.00 & 2.15 \\
\hline Cold finishing of steel shapes & 3316 & 0.114 & 0.22 & 0.66 & 0.88 & 0.88 & 0.66 & 0.44 & 0.44 & 0.22 & 0.00 & 0.00 & 0.00 & 0.00 & 4.39 \\
\hline Primary nonferrous metals, NEC ${ }^{c}$ & 3339 & 0.016 & 0.00 & 0.01 & 0.02 & 0.02 & 0.01 & 0.01 & 0.01 & 0.00 & 0.00 & 0.00 & 0.00 & 0.00 & 0.08 \\
\hline Copper rolling and drawing & $335 i$ & 0.020 & 0.00 & 0.00 & 0.00 & 0.00 & 0.00 & 0.00 & 0.00 & 0.00 & 0.00 & 0.00 & 0.00 & 0.00 & 0.02 \\
\hline Nonferrous wire drawing and insulating & 3357 & 0.023 & 0.25 & 0.75 & 1.00 & 1.00 & 0.75 & 0.50 & 0.50 & 0.25 & 0.00 & 0.00 & 0.00 & 0.00 & 5.01 \\
\hline Fabricated structural metal & 3441 & 0.013 & 0.03 & 0.08 & 0.11 & 0.11 & 0.08 & 0.06 & 0.06 & 0.03 & 0.05 & 0.83 & 0.00 & 0.00 & 1.39 \\
\hline Fabricated plate work & 3443 & 0.008 & 0.08 & 0.25 & 0.33 & 0.33 & 0.25 & 0.17 & 0.17 & 0.08 & 0.14 & 2.51 & 0.00 & 0.00 & 4.18 \\
\hline Iron and steel forging & 3462 & 0.026 & 0.02 & 0.06 & 0.08 & 0.08 & 0.06 & 0.04 & 0.04 & 0.02 & 0.03 & 0.63 & 0.00 & 0.00 & 1.04 \\
\hline Plating and polishing & 3471 & 0.026 & 0.01 & 0.03 & 0.05 & 0.05 & 0.03 & 0.02 & 0.02 & 0.01 & 0.02 & 0.34 & 0.00 & 0.00 & 0.57 \\
\hline Pipe, valves, and pipe fittings & 3498 & 0.019 & 0.02 & 0.05 & 0.07 & 0.07 & 0.05 & 0.04 & 0.04 & 0.02 & 0.03 & 0.53 & 0.00 & 0.00 & 0.89 \\
\hline Conveyors and conveying equipment & 3535 & 0.018 & 0.02 & 0.04 & 0.05 & 0.05 & 0.04 & 0.06 & 0.07 & 0.06 & 0.03 & 0.62 & 0.00 & 0.00 & 1.02 \\
\hline Hoists, cranes, and monorails & 3536 & 0.051 & 0.03 & 0.07 & 0.09 & 0.09 & 0.07 & 0.11 & 0.12 & 0.10 & 0.06 & 1.05 & 0.00 & 0.00 & 1.72 \\
\hline Machinery and equipment & 354 & 0.023 & 0.23 & 0.69 & 0.91 & 0.91 & 0.69 & 0.46 & 0.46 & 0.23 & 0.05 & 0.97 & 0.00 & 0.00 & 5.54 \\
\hline Pumps and compressors & 3561,3563 & 0.038 & 0.16 & 0.41 & 0.54 & 0.54 & 0.41 & 0.67 & 0.73 & 0.60 & 0.36 & 6.40 & 0.00 & 0.00 & 10.46 \\
\hline Blowers and fans & 3564 & 0.037 & 0.00 & 0.01 & 0.02 & 0.02 & 0.01 & 0.02 & 0.02 & 0.02 & 0.01 & 0.19 & 0.00 & 0.00 & 0.31 \\
\hline General industrial machinery, NEC & 3569 & 0.027 & 0.03 & 0.07 & 0.09 & 0.09 & 0.07 & 0.11 & 0.12 & 0.10 & 0.06 & 1.04 & 0.00 & 0.00 & 1.70 \\
\hline Electronic computers & 3571 & 0.091 & 0.24 & 0.48 & 0.60 & 0.60 & 0.48 & 1.84 & 2.09 & 1.96 & 1.81 & 32.65 & 0.00 & 0.00 & 40.95 \\
\hline Refrigeration and heating equipment & 3585 & 0.006 & 0.00 & 0.01 & 0.01 & 0.01 & 0.01 & 0.00 & 0.00 & 0.00 & 0.01 & 0.22 & 0.00 & 0.00 & 0.25 \\
\hline Service industry machines, NEC & 3589 & 0.040 & 0.00 & 0.01 & 0.01 & 0.01 & 0.01 & 0.00 & 0.00 & 0.00 & 0.01 & 0.27 & 0.00 & 0.00 & 0.31 \\
\hline Industrial machines, NEC & 3599 & 0.022 & 0.00 & 0.01 & 0.01 & 0.01 & 0.01 & 0.01 & 0.01 & 0.01 & 0.00 & 0.08 & 0.00 & 0.00 & 0.14 \\
\hline Transformers & 3612 & 0.017 & 0.00 & 0.01 & 0.02 & 0.02 & 0.01 & 0.01 & 0.01 & 0.00 & 0.00 & 0.00 & 0.00 & 0.00 & 0.08 \\
\hline Switchgear and switchboard apparatus & 3613 & 0.038 & 0.02 & 0.05 & 0.07 & 0.07 & 0.05 & 0.03 & 0.03 & 0.02 & 0.00 & 0.00 & 0.00 & 0.00 & 0.34 \\
\hline Motors and generators & 3621 & 0.032 & 0.00 & 0.00 & 0.01 & 0.01 & 0.00 & 0.00 & 0.00 & 0.00 & 0.00 & 0.00 & 0.00 & 0.00 & 0.03 \\
\hline Electric industrial apparatus, NEC & 3629 & 0.037 & 0.07 & 0.20 & 0.26 & 0.26 & 0.20 & 0.13 & 0.13 & 0.07 & 0.00 & 0.00 & 0.00 & 0.00 & 1.32 \\
\hline Electronic components, NEC & 3679 & 0.035 & 0.08 & 0.24 & 0.31 & 0.31 & 0.24 & 0.16 & 0.16 & 0.08 & 0.00 & 0.00 & 0.00 & 0.00 & 1.57 \\
\hline Electric equipment, NEC & 3699 & 0.030 & 0.08 & 0.10 & 0.11 & 0.11 & 0.10 & 0.75 & 0.86 & 0.85 & 0.61 & 10.95 & 0.00 & 0.00 & 13.91 \\
\hline Mechanical measuring devices & 3823,3829 & 0.021 & 0.03 & 0.10 & 0.13 & 0.13 & 0.10 & 0.06 & 0.06 & 0.03 & 0.00 & 0.00 & 0.00 & 0.00 & 0.64 \\
\hline Electric services & 4911 & 0.500 & 0.00 & 0.00 & 0.00 & 0.00 & 0.00 & 0.00 & 0.00 & 0.00 & 17.60 & 316.80 & 0.00 & 0.00 & 316.80 \\
\hline Water supply and sewerage services & 4941 & 1.000 & 1.16 & 3.50 & 4.66 & 4.66 & 3.50 & 2.34 & 2.34 & 1.16 & 1.20 & 21.57 & 100.00 & 400.00 & 444.89 \\
\hline Sanitary services and steam supply & 495,4953 & 0.500 & 0.00 & 0.00 & 0.00 & 0.00 & 0.00 & 0.00 & 0.00 & 0.00 & 4.68 & 84.25 & 0.00 & 0.00 & 84.25 \\
\hline Engineering and architectural services & 8711,8712 & 0.015 & 0.01 & 0.02 & 0.03 & 0.03 & 0.02 & 0.01 & 0.01 & 0.01 & 0.00 & 0.00 & 0.00 & 0.00 & 0.14 \\
\hline Research, development, and testing services & 8733,8734 & 0.017 & 0.02 & 0.07 & 0.09 & 0.09 & 0.07 & 0.05 & 0.05 & 0.02 & 0.00 & 0.00 & 0.00 & 0.00 & 0.47 \\
\hline Federal govermment, nonmilitary & Host labor & 1.000 & 76.14 & 180.92 & 233.31 & 233.31 & 180.92 & 155.52 & 160.02 & 107.64 & 58.24 & $1,048.32$ & 150.00 & 600.00 & $2,976.10$ \\
\hline Non-host labor & Non-host labor & 1.000 & 58.74 & 94.29 & 112.06 & 112.06 & 94.29 & 123.09 & 130.85 & 113.08 & 57.13 & $1,028.38$ & 0.00 & 0.00 & $1,866.83$ \\
\hline Total & & & 151.89 & 325.81 & 412.76 & 412.76 & 325.81 & 315.13 & 327.84 & 240.88 & 143.12 & $2,576.21$ & 250.00 & $1,000.00$ & 6.089 .10 \\
\hline
\end{tabular}

2 Costs are given in millions of dollars.

b SIC codes are from the 1987 Standard Industrial Classification Manual. BEA accounts are from the 1982 Benchmark Input-Output Accounts of the United States.

c NEC $=$ not elsewhere classified.

d Host labor costs in local areas have been adjusted for certain construction phase functions occurring in other U.S. locations.

c Non-host labor expenditures are calculated by adjusting "total non-host labor costs at site" as follows: (I) five-sixths of the labor cost pays for the scientists/engineers located at the host site, and one-sixth pays for support at the home institution; and (2) of the labor payments made to the scientists/engineers at the host site, only $69 \%$ is actually spent at the site; the remaining $31 \%$ is for taxes, pension contributions, and other payments made in home countries. 


\begin{tabular}{|c|c|c|c|c|c|c|c|c|c|c|c|c|c|c|c|}
\hline \multirow[b]{2}{*}{ Sector } & \multirow[b]{2}{*}{$\begin{array}{c}\text { SIC/BEA } \\
\text { Code }^{b}\end{array}$} & \multirow[b]{2}{*}{ LPC } & \multicolumn{8}{|c|}{ Construction Costs ${ }^{\mathrm{a}}$} & \multicolumn{2}{|c|}{ Operating Costs ${ }^{a}$} & \multicolumn{2}{|c|}{$\begin{array}{c}\text { Decommissioning } \\
\text { Costsaa }\end{array}$} & \multirow[b]{2}{*}{$\begin{array}{l}\text { Total } \\
\text { Costs } \\
\end{array}$} \\
\hline & & & 1999 & 2000 & 2001 & 2002 & 2003 & 2004 & 2005 & 2006 & 2007 & $2007-2024$ & 2025 & $2025-2028$ & \\
\hline New industrial and commercial buildings & 1796. 1799 & 0.950 & 13.26 & 39.78 & 53.04 & 53.04 & 39.78 & 26.51 & 26.51 & 13.26 & 0.00 & 0.00 & 0.00 & 0.00 & 265.18 \\
\hline New utility structures & BEA $11(303,306)$ & 0.950 & 0.84 & 2.52 & 3.36 & 3.36 & 2.52 & 1.68 & 1.68 & 0.84 & 0.00 & 0.00 & 0.00 & 0.00 & 16.80 \\
\hline Chemicals and allied products & 28 & 0.038 & 0.00 & 0.00 & 0.01 & 0.01 & 0.00 & 0.00 & 0.00 & 0.00 & 0.56 & 10.10 & 0.00 & 0.00 & 10.13 \\
\hline Petroleum refining & $29 t$ & 0.041 & 0.00 & 0.00 & 0.00 & 0.00 & 0.00 & 0.00 & 0.00 & 0.00 & 0.42 & 7.50 & 0.00 & 0.00 & 7.50 \\
\hline Ready-mix conerete & 3273 & 0.950 & 0.10 & 0.32 & 0.43 & 0.43 & 0.32 & 0.22 & 0.22 & 0.10 & 0.00 & 0.00 & 0.00 & 0.00 & 2.15 \\
\hline Cold finishing of steel shapes & 3316 & 0.114 & 0.22 & 0.66 & 0.88 & 0.88 & 0.66 & 0.44 & 0.44 & 0.22 & 0.00 & 0.00 & 0.00 & 0.00 & 4.39 \\
\hline Copper rolling and drawing & 3351 & 0.020 & 0.00 & 0.00 & 0.00 & 0.00 & 0.00 & 0.00 & 0.00 & 0.00 & 0.00 & 0.00 & 0.00 & 0.00 & 0.02 \\
\hline Nonferrous wire drawing and insulating & 3357 & 0.023 & 0.25 & 0.75 & 1.00 & 1.00 & 0.75 & 0.50 & 0.50 & 0.25 & 0.00 & 0.00 & 0.00 & 0.00 & 5.01 \\
\hline Fabricated structural metal & 3441 & 0.013 & 0.03 & 0.08 & 0.11 & 0.11 & 0.08 & 0.06 & 0.06 & 0.03 & 0.05 & 0.83 & 0.00 & 0.00 & 1.39 \\
\hline Fabricated plate work & 3443 & 0.008 & 0.08 & 0.25 & 0.33 & 0.33 & 0.25 & 0.17 & 0.17 & 0.08 & 0.14 & 2.51 & 0.00 & 0.00 & 4.18 \\
\hline Iron and steel forging & 3462 & 0.026 & 0.02 & 0.06 & 0.08 & 0.08 & 0.06 & 0.04 & 0.04 & 0.02 & 0.03 & 0.63 & 0.00 & 0.00 & 1.04 \\
\hline Plating and polishing & 3471 & 0.026 & 0.01 & 0.03 & 0.05 & 0.05 & 0.03 & 0.02 & 0.02 & 0.01 & 0.02 & 0.34 & 0.00 & 0.00 & 0.57 \\
\hline Pipe, valves, and pipe fittings & 3498 & 0.019 & 0.02 & 0.05 & 0.07 & 0.07 & 0.05 & 0.04 & 0.04 & 0.02 & 0.03 & 0.53 & 0.00 & 0.00 & 0.89 \\
\hline Conveyors and conveying equipment & 3535 & 0.018 & 0.02 & 0.04 & 0.05 & 0.05 & 0.04 & 0.06 & 0.07 & 0.06 & 0.03 & 0.62 & 0.00 & 0.00 & 1.02 \\
\hline Hoists, cranes, and monorails & 3536 & 0.051 & 0.03 & 0.07 & 0.09 & 0.09 & 0.07 & 0.11 & 0.12 & 0.10 & 0.06 & 1.05 & 0.00 & 0.00 & 1.72 \\
\hline Machinery and equipment & 354 & 0.023 & 0.23 & 0.69 & 0.91 & 0.91 & 0.69 & 0.46 & 0.46 & 0.23 & 0.05 & 0.97 & 0.00 & 0.00 & 5.54 \\
\hline General industrial machinery. NEC & 3569 & 0.027 & 0.03 & 0.07 & 0.09 & 0.09 & 0.07 & 0.11 & 0.12 & 0.10 & 0.06 & 1.04 & 0.00 & 0.00 & 1.70 \\
\hline Electronic computers & 3571 & 0.091 & 0.24 & 0.48 & 0.60 & 0.60 & 0.48 & 1.84 & 2.09 & 1.96 & 1.81 & 32.65 & 0.00 & 0.00 & 40.95 \\
\hline Refrigeration and heating equipment & 3585 & 0.006 & 0.00 & 0.01 & 0.01 & 0.01 & 0.01 & 0.00 & 0.00 & 0.00 & 0.01 & 0.22 & 0.00 & 0.00 & 0.25 \\
\hline Service industry machines, NEC & 3589 & 0.040 & 0.00 & 0.01 & 0.01 & 0.01 & 0.01 & 0.00 & 0.00 & 0.00 & 0.01 & 0.27 & 0.00 & 0.00 & 0.31 \\
\hline Industrial machines, NEC & 3599 & 0.022 & 0.00 & 0.01 & 0.01 & 0.01 & 0.01 & 0.01 & 0.01 & 0.01 & 0.00 & 0.08 & 0.00 & 0.00 & 0.14 \\
\hline Transformers & 3612 & 0.017 & 0.00 & 0.01 & 0.02 & 0.02 & 0.01 & 0.01 & 0.01 & 0.00 & 0.00 & 0.00 & 0.00 & 0.00 & 0.08 \\
\hline Switchgear and switchboard apparatus & 3613 & 0.038 & 0.02 & 0.05 & 0.07 & 0.07 & 0.05 & 0.03 & 0.03 & 0.02 & 0.00 & 0.00 & 0.00 & 0.00 & 0.34 \\
\hline Motors and generators & 3621 & 0.032 & 0.00 & 0.00 & 0.01 & 0.01 & 0.00 & 0.00 & 0.00 & 0.00 & 0.00 & 0.00 & 0.00 & 0.00 & 0.03 \\
\hline Electric industrial apparatus, NEC & 3629 & 0.037 & 0.07 & 0.20 & 0.26 & 0.26 & 0.20 & 0.13 & 0.13 & 0.07 & 0.00 & 0.00 & 0.00 & 0.00 & 1.32 \\
\hline Electronic components, NEC & 3679 & 0.035 & 0.08 & 0.24 & 0.31 & 0.31 & 0.24 & 0.16 & 0.16 & 0.08 & 0.00 & 0.00 & 0.00 & 0.00 & 1.57 \\
\hline Electric equipment, NEC & 3699 & 0.030 & 0.08 & 0.10 & 0.11 & 0.11 & 0.10 & 0.75 & 0.86 & 0.85 & 0.61 & 10.95 & 0.00 & 0.00 & 13.91 \\
\hline Mechanical measuring devices & 3823,3829 & 0.021 & 0.03 & 0.10 & 0.13 & 0.13 & 0.10 & 0.06 & 0.06 & 0.03 & 0.00 & 0.00 & 0.00 & 0.00 & 0.64 \\
\hline Electric services & 4911 & 0.500 & 0.00 & 0.00 & 0.00 & 0.00 & 0.00 & 0.00 & 0.00 & 0.00 & 17.60 & 316.80 & 0.00 & 0.00 & 316.80 \\
\hline Water supply and sewerage services & 4941 & 1.000 & 1.16 & 3.50 & 4.66 & 4.66 & 3.50 & 2.34 & 2.34 & 1.16 & 1.20 & 21.57 & 100.00 & 400.00 & 444.89 \\
\hline Sanitary services and steam supply & 495.4953 & 0.500 & 0.00 & 0.00 & 0.00 & 0.00 & 0.00 & 0.00 & 0.00 & 0.00 & 4.68 & 84.25 & 0.00 & 0.00 & 84.25 \\
\hline Engineering and architectural services & 8711,8712 & 0.015 & 0.01 & 0.02 & 0.03 & 0.03 & 0.02 & 0.01 & 0.01 & 0.01 & 0.00 & 0.00 & 0.00 & 0.00 & 0.14 \\
\hline Research, development, and testing services & 8733,8734 & 0.017 & 0.02 & 0.07 & 0.09 & 0.09 & 0.07 & 0.05 & 0.05 & 0.02 & 0.00 & 0.00 & 0.00 & 0.00 & 0.47 \\
\hline Federal government, nonmilitary & Host labor" & 1.000 & 73.99 & 174.47 & 224.71 & 224.71 & 174.47 & 151.22 & 155.72 & 105.19 & 58.24 & $1,048.32$ & 75.00 & 300.00 & $2,632,80$ \\
\hline Non-host labor & Non-host labore & 1.000 & 60.04 & 98.17 & 117.23 & 117.23 & 98.17 & 125.66 & 133.44 & 114.37 & 57.13 & $1,028.38$ & 43.13 & 172.50 & $2,065.20$ \\
\hline Total & & & 151.04 & 323.24 & 409.33 & 409.33 & 323.24 & 313.42 & 326.13 & 239.72 & 143.12 & $2,576.21$ & 218.13 & 872.50 & 5.944 .18 \\
\hline
\end{tabular}

a Costs are given in millions of dollars.

b SIC codes are from the 1987 Standard Industrial Classification Manual. BEA accounts are from the 1982 Benchmark Inpul-Output Accounts of the United States.

c $\mathrm{NEC}=$ not elsewhere classified.

d Host labor cosis in local areas have been adjusted for certain construction phase functions occurring in other U.S. locations.

- Non-host labor expenditures are calculated by adjusting "Lotal non-host labor costs at site" as follows: (1) five-sixths of the labor cost pays for the scientists/engineers located at the host site, and one-sixth pays for support at the home institution; and (2) of the labor payments made to the scientists/engincers at the host site, only $69 \%$ is actually spent at the site; the remaining $31 \%$ is for taxes, pension contributions, and other payments made in home countries. 


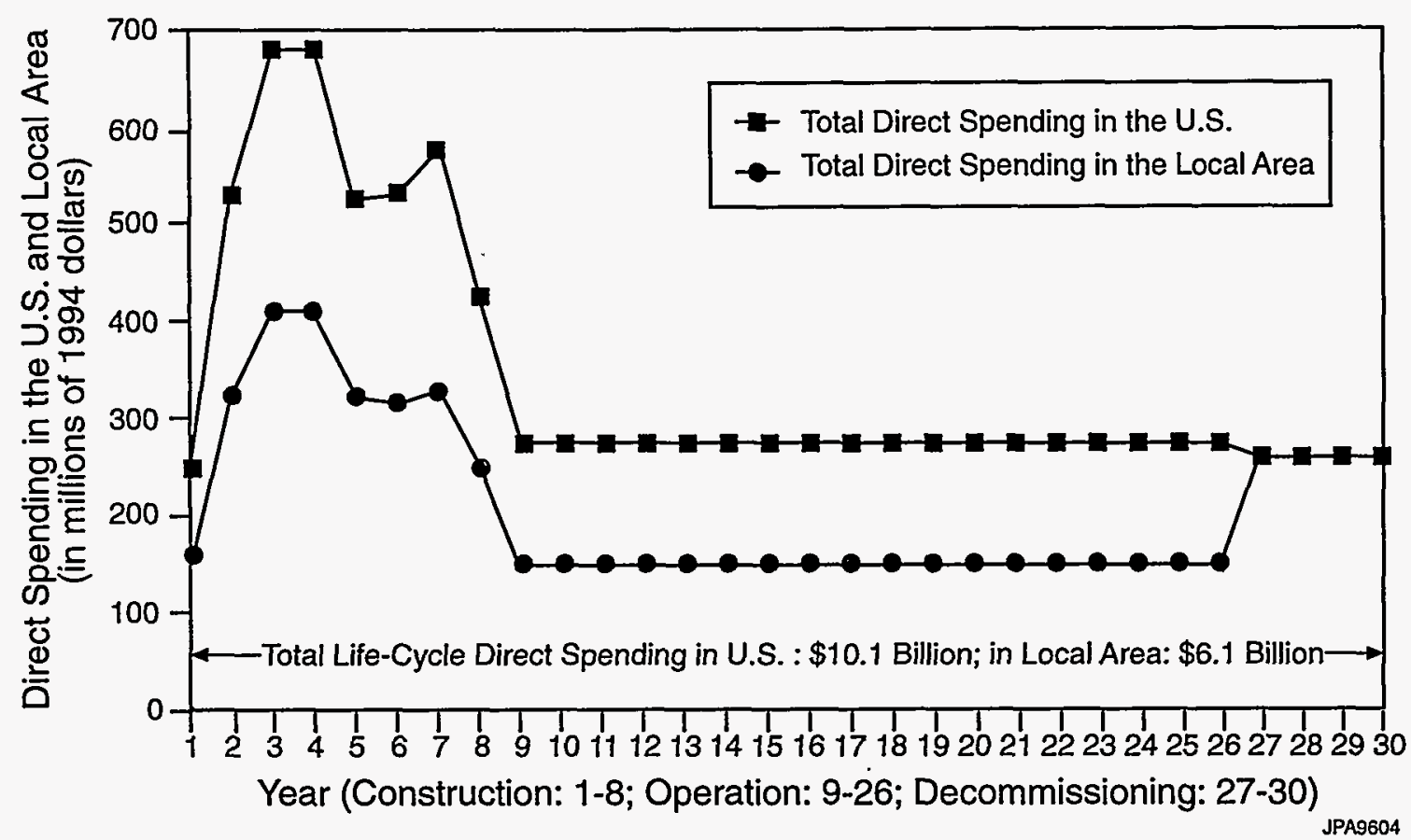

FIGURE 19 Direct Spending in the U.S. and Local Area: Reference Case

The relatively low LPCs for the manufacturing sectors mean that direct spending and thus the economic impacts of the project are determined largely by work force spending in the local economy and by ITER purchases from locally supplied goods and services. Of these two elements, spending by on-site host/non-host workers contributes more to local economic benefits. Over the entire 30-year life cycle of the project, host direct labor payments in the local area would exceed $\$ 2.9$ billion and non-host labor payments would exceed $\$ 1.8$ billion under the reference case. Equivalent expenditures under the increased non-host participation case would be $\$ 2.6$ billion and $\$ 2$ billion, respectively. The non-host case spending estimates are slightly higher under the increased non-host participation case because of the increased sharing of assembly costs by non-host participants under this scenario. Non-host participants also provide a larger share of decommissioning costs under the increased non-host participation case.

Local area spending for nonlabor items would be dominated by purchases of water and sewerage services (which include all waste disposal services), electricity, and construction of new buildings at the site. The total benefits of ITER to a local area, however, extend beyond the direct local spending that occurs in the construction, operation, and decommissioning of ITER. Additional benefits result from the indirect impacts in the secondary supplying sectors and from the induced impacts from spending by households as a result of direct and indirect expenditures. The indirect and induced impacts on output, personal income, and employment are measured in the form of multipliers for each sector in which direct spending occurs. 
Output multipliers measure the cumulative change that occurs in local area production for each dollar of ITER spending in a sector. Personal income multipliers measure the cumulative change in a local area's household or personal income for each dollar of ITER spending in a sector of the local economy. Employment multipliers measure the cumulative change in total employment in a local area due to ITER spending in each sector. The employment multipliers used in this study reflect the change in total (full- and part-time) employment for each \$1 million of ITER spending in a sector. While both full- and part-time employment are reflected in the multipliers, these estimates reflect existing employment patterns in each sector.

Although the MMLAN model provides spending multipliers for low-, middle-, and highincome individuals, the employment multipliers for the labor spending categories were adjusted on the basis of information provided by the DOE. Under this adjustment, each $\$ 300,000$ of non-host direct spending on labor provides for two direct scientific/engineering jobs and two administrative/support jobs. For each $\$ 300,000$ in non-host direct labor spending, $\$ 250,000$ is spent in the local area, and the remaining $\$ 50,000$ is returned to the non-host country for support at research institutions there. Of the $\$ 250,000$ spent in the local area, only $69 \%$ of the labor payment is made in the local area. Thirty-one percent of non-host labor payments is returned to the non-host country for taxes, retirement contributions, and other expenses.

Output, personal income, and employment multipliers for each sector were calculated for each of the six metropolitan areas studied in this analysis. Average multipliers were then calculated and adjusted to reflect 1994 dollars. The average output, personal income, and employment multiplier for each local area sector are shown in Table 10.

\subsubsection{Reference Case}

The project will provide significant economic benefits to a local/regional area that serves as the ITER site under the reference case. Benefits in local employment, personal income, and output are discussed here.

The number of workers directly employed at the ITER site was determined by multiplying the estimated number of jobs per dollar of expenditure on direct labor by the labor expenditure expected at the site. The number of direct host/non-host workers expected to be employed in a local/regional area is shown in Table 13. Direct employment would peak at approximately 4,400 workers during the third and fourth years of construction and maintain approximately 1,400 workers during operation. Host workers would make up 52-71\% of all ITER workers during construction and 54\% during operation. Host ITER workers would solely be responsible for decommissioning activities under the reference case. 
TABLE 13 Local Area Primary Jobs Created: Reference Case

\begin{tabular}{cccc}
\hline Year & $\begin{array}{c}\text { Primary } \\
\text { Host } \\
\text { Jobs }\end{array}$ & $\begin{array}{c}\text { Primary } \\
\text { Non-Host } \\
\text { Jobs }\end{array}$ & $\begin{array}{c}\text { Total } \\
\text { Primary } \\
\text { Jobs }\end{array}$ \\
\hline 1999 & 1,015 & 681 & 1,696 \\
2000 & 2,412 & 1,093 & 3,505 \\
2001 & 3,111 & 1,299 & 4,410 \\
2002 & 3,111 & 1,299 & 4,410 \\
2003 & 2,412 & 1,093 & 3,505 \\
2004 & 2,074 & 1,427 & 3,501 \\
2005 & 2,134 & 1,517 & 3,651 \\
2006 & 1,435 & 1,311 & 2,746 \\
$2007 .-2024^{\mathrm{a}}$ & 777 & 662 & 1,439 \\
$2025-2027^{\mathrm{a}}$ & 2,000 & 0 & 2,000 \\
\hline
\end{tabular}

a Average annual values.

The total benefits of ITER in a local/regional area would extend beyond direct employment at the ITER facility. Additional benefits would accrue from the indirect impacts of the project in secondary supplying sectors and the induced impacts from spending by households as a result of direct and indirect expenditures in the sectors supplying the project. The average total employment benefit at the local/regional area is shown in Table 14. Total employment would peak at approximately 11,200 new jobs during the third and fourth years of construction, maintain approximately 3,800 new jobs during operation, and increase to about 6,800 new jobs during decommissioning. These increases represent approximately $0.95 \%$ (construction), $0.33 \%$ (operation), and $0.58 \%$ (decommissioning) of the average existing employment in the six metropolitan areas.

Total employment benefits could vary from those presented in Table 14, depending on the characteristics of the specific site chosen. For an area with a smaller economy, the absolute benefits of the project would be less than those for an area with a larger economy, because a larger proportion of direct, indirect, and induced project expenditures would likely be made outside the local area. On the other hand, areas with smaller economies are likely to see more significant relative increases in local employment benefits.

The project will also provide significant personal income benefits, mainly from the payments made to direct and indirect labor. Table 14 shows the estimated average impact on local personal income. Local area personal income impacts would peak at nearly $\$ 382$ million during the 
TABLE 14 Local Area Output, Personal Income, and Employment Benefits: Reference Case

\begin{tabular}{crrr}
\hline & \multicolumn{2}{c}{$\begin{array}{c}\text { Millions of } \\
\text { 1994 Dollars }\end{array}$} \\
\cline { 2 - 3 } Year & Output & $\begin{array}{c}\text { Personal } \\
\text { Income }\end{array}$ & \\
\cline { 2 - 3 } 1999 & 257.0 & 134.4 & 4,422 \\
2000 & 549.8 & 299.6 & 8,981 \\
2001 & 696.2 & 382.1 & 11,260 \\
2002 & 696.2 & 382.1 & 11,260 \\
2003 & 549.8 & 299.6 & 8,981 \\
2004 & 533.6 & 277.3 & 9,183 \\
2005 & 555.2 & 287.4 & 9,596 \\
2006 & 408.8 & 204.8 & 7,317 \\
$2007-2024^{\mathrm{a}}$ & 235.7 & 112.1 & 3,880 \\
$2025-2028^{\mathrm{a}}$ & 450.4 & 234.2 & 6,850 \\
Total $^{3}$ & 10,291 & $5,221.0$ & $\mathrm{~b}$ \\
\hline
\end{tabular}

a Average annual values.

b Not applicable.

third and fourth years of construction, fall to approximately $\$ 112$ million during operation, and increase to approximately $\$ 234$ million during decommissioning. Personal income would increase by approximately $\$ 5.2$ billion over the life of the project. The estimated increases represent a significant impact on the local area. With an average payroll of $\$ 32.4$ billion for the six metropolitan areas studied, the project would increase local personal income by $1.2 \%$ during peak construction, almost $0.4 \%$ during operation, and $0.7 \%$ during decommissioning. Larger percentage increases in local income would occur in smaller economies than would occur in larger economies.

Local area producers would see their output increase through direct sales to the ITER project and increased purchases by other firms in the area and by local households. Table 14 shows the estimated average impact on local area output under the reference case. The total increase in local area output would peak at approximately $\$ 696$ million during the third and fourth years of construction, increase by approximately $\$ 236$ million each year during operation, and climb to more than $\$ 450$ million per year during decommissioning. Output would increase by more than $\$ 10$ billion over the life of the project. Absolute increases in local area output would be larger in larger local 
economies because more impacts would be captured in the local economy. Relative increases would also be larger in smaller economies.

The output, personal income, and employment benefits represent the average impact to be expected in a range of U.S. locations that might serve as the ITER site. The actual benefits experienced by a specific locality would depend on the size of the local economy and the extent to which the local economy is diversified over different economic sectors. As a general rule, the absolute amount of economic benefit associated with ITER would likely be higher in larger metropolitan areas with highly diversified economies than in smaller metropolitan areas. For example, in the reference case, peak employment due to ITER in the largest metropolitan area studied would be approximately $16 \%$ higher than that reported in Table 14 . Peak employment impacts in the smallest metropolitan area would be approximately $19 \%$ lower. Similarly, average output would be approximately $28 \%$ higher than the output impacts shown in Table 14 for the largest metropolitan area and approximately $17 \%$ lower for the smallest metropolitan area.

Although the absolute ITER-induced economic benefit is likely to be highest in larger metropolitan areas, the relative impacts of ITER are likely to be largest in smaller metropolitan areas. For example, the average economic benefit generally represents an increase of less than $1 \%$ in existing local output, personal income, or employment. These relative impacts could more than double in some smaller metropolitan areas.

\subsubsection{Increased Non-Host Participation Case}

The ITER project will provide significant economic benefits to a local/regional area under the increased non-host participation case. The slightly lower overall spending during construction and decommissioning under this case reduces economic benefits to the local area to slightly lower than those estimated for the reference case.

Table 15 shows host and non-host direct employment under the increased non-host participation case. Total direct employment would be lower during construction under this scenario than in the reference case, but never by less than 55 workers per year. Direct employment during operation would be identical to that under the reference case (approximately 1,400 workers per year) and lower by 500 jobs per year during decommissioning.

The cumulative impacts of ITER on local employment are shown in Table 16. Only slight differences from the reference case would occur, except during decommissioning. During that time, total regional employment would increase by 5,607 workers, or approximately 1,200 fewer jobs than under the reference case. 
TABLE 15 Local Area Primary Jobs Created: Increased Non-Host Participation Case

\begin{tabular}{crrr}
\hline & $\begin{array}{c}\text { Primary } \\
\text { Host Jobs }\end{array}$ & $\begin{array}{c}\text { Primary } \\
\text { Non-Host Jobs }\end{array}$ & $\begin{array}{c}\text { Total } \\
\text { Primary Jobs }\end{array}$ \\
\hline 1999 & 987 & 696 & 1,683 \\
2000 & 2,326 & 1,138 & 3,464 \\
2001 & 2,996 & 1,359 & 4,355 \\
2002 & 2,996 & 1,359 & 4,355 \\
2003 & 2,326 & 1,138 & 3,464 \\
2004 & 2,016 & 1,457 & 3,473 \\
2005 & 2,076 & 1,547 & 3,623 \\
2006 & 1,403 & 1,326 & 2,728 \\
$2007-2024^{\mathrm{a}}$ & 777 & 662 & 1,439 \\
$2025-2028^{\mathrm{a}}$ & 1,000 & 500 & 1,500 \\
\hline
\end{tabular}

a Average annual values.

TABLE 16 Local Area Output, Personal Income, and Employment Benefits: Increased Non-Host Participation Case

\begin{tabular}{cccc}
\hline & \multicolumn{2}{c}{ Millions of } \\
& \multicolumn{2}{c}{ 1994 dollars } \\
\cline { 2 - 3 } Year & Output & $\begin{array}{c}\text { Personal } \\
\text { Income }\end{array}$ & Employment \\
\cline { 2 - 3 } 1999 & 255.67 & 132.51 & 4,420 \\
2000 & 545.8 & 293.8 & 8,975 \\
2001 & 690.8 & 374.5 & 11,252 \\
2002 & 690.8 & 374.5 & 11,252 \\
2003 & 545.8 & 293.8 & 8,975 \\
2004 & 530.9 & 273.5 & 9,179 \\
2005. & 552.6 & 283.5 & 9,592 \\
2006 & 407.0 & 202.5 & 7,308 \\
$2007-2024^{\mathrm{a}}$ & 235.7 & 112.1 & 3,880 \\
$2025-2028^{\mathrm{a}}$ & 400.2 & 166.4 & 5,607 \\
Total & 10,063 & 4,912 & $\mathrm{~b}$ \\
\hline
\end{tabular}

a Average annual values.

b Not applicable. 
The cumulative impacts of ITER on local personal income are also shown in Table 16. Over the life of the project, total regional personal income under the increased non-host participation case would be approximately $\$ 309$ million lower than that under the reference case. This small decrease is caused by the relatively smaller direct ITER workforce required under the increased non-host participation case and the leakage from the local/national economies that would occur when salaries are paid to non-host workers.

The cumulative impacts of ITER on the production and sales of local area businesses are shown in Table 16. The distribution of output impacts over time under the increased non-host participation case remains almost identical to that under the reference case, although the total output increase over the life of the project is slightly lower. 


\section{SUMMARY AND OBSERVATIONS}

This section summarizes the major findings of the national and local/regional economic analyses and identifies additional factors that must be considered in weighing the costs and benefits of participating in the ITER program, whether as host or as non-host. General observations about ITER and the long-term benefits of fusion energy are also provided.

\subsection{SUMMARY OF STUDY RESULTS}

The national and local/regional economic impacts of ITER described in Section 5 are intuitive in many ways. They are short term in nature because they arise from direct ITER expenditures during facility construction, operation, and decommissioning. Nevertheless, they help to put ITER life-cycle expenditures and possible host/non-host cost-sharing arrangements into perspective by quantifying the expected magnitude of impacts (positive and negative) and identifying important economic factors and relationships. Key study results are as follows:

- ITER Life-Cycle Costs. Study results are based on estimated ITER expenditures over a 30-year life cycle consisting of an 8-year construction phase (1999-2006), an 18-year operation phase (2007-2024), and a 4-year decommissioning phase (2025-2028). The total life-cycle costs in 1994 dollars are $\$ 19.64$ billion: $\$ 10$ billion for construction, $\$ 8.64$ billion for operation, and $\$ 1$ billion for decommissioning. The construction cost includes $\$ 6.8$ billion for construction capital (i.e., buildings and structures, magnets, auxiliaries, and assembly) and $\$ 3.2$ billion for other construction activities: design and management, R\&D during construction, and preparation for operation. These construction cost categories (capital and other) account for $35 \%$ and $16 \%$ of the total life-cycle cost ( $\$ 19.64$ billion), respectively. Decommissioning accounts for $5 \%$ of the total life-cycle cost.

- Host/Non-Host Cost Sharing. In the reference study case, which assumes four cost-sharing Parties (a host and three equal-share, non-host Parties), the ITER host is responsible for approximately $\$ 7.99$ billion ( $40 \%$ ) of the $\$ 19.64$ billion ITER life-cycle cost. Each non-host Party is responsible for approximately $\$ 3.88$ billion. (20\%). Expenditures by non-host Parties at the host site (primarily for labor) would be approximately $\$ 2.08$ billion. Therefore, if the U.S. hosted ITER, total expenditures in the U.S. would be approximately $\$ 10.07$ billion, of which $\$ 7.99$ billion would come from the federal budget. If the U.S. participated as a full-share non-host, total federal spending on ITER would amount to $\$ 3.88$ billion, of which only $\$ 3.19$ billion would be 
spent in the U.S. This situation would occur because U.S. scientists and engineers would spend money (estimated at $\$ 0.69$ billion) at a host site outside the U.S.

- GDP Impacts. Hosting ITER would result in positive short-term economic benefits - as measured by GDP - in the U.S. under all conditions analyzed in the study. The source of U.S. funding for ITER is an important factor in determining the overall magnitude of such benefits. Gross domestic product could increase by as much as $\$ 1.2$ billion per year during construction, if supplemental federal funds financed the U.S. portion of the project. However, the long-term economic consequences of assuming such debt to fund ITER were not considered. If the federal budget were not increased to finance ITER, which implies a realignment of existing federal nondefense programs, the short-term increase in GDP would fall to approximately $\$ 200$ million per year at its peak. While different in magnitude, neither of these estimated impacts on GDP is significant in the context of the $\$ 7$ trillion overall U.S. economy. If the U.S. were a full-share, non-host participant in ITER, GDP would decline by approximately $\$ 100$ million annually because of expenditures outside the U.S.

- National Employment Impacts. The impacts of ITER on national employment are minimal relative to the large national labor force (estimated in the analysis to be approximately 136 million at the start of ITER construction). With supplemental federal funding for the U.S. share, national employment could increase by as many as 8,000 jobs at the peak of construction if the U.S. were the host. For a realignment of the federal nondefense budget, an increase of about 1,000 jobs is expected. During the operation and decommissioning phases, the increase would be about 2,000 jobs under all conditions examined.

- Net Export Impacts. Net exports would generally increase under most conditions examined if the U.S. were the host. This increase occurs because expenditures by non-host workers in the U.S. (counted as exports) are greater than the increase in imports due to ITER. The maximum increase in net exports for a realignment of existing nondefense federal programs is $\$ 111$ million per year. When supplemental funds are assumed, the increase in net exports is estimated to be $\$ 75$ million in the peak year.

- Disposable Income Impacts. Disposable income increases when the U.S. is the host primarily because of increased GDP. With supplemental funding for the U.S. share, disposable income increases by $\$ 1.79$ per capita during peak construction. For a realignment of existing nondefense federal programs, 
disposable income increases by approximately $\$ 0.39$ per capita in the peak year.

- Host Versus Non-Host National-Level Economic Impacts. While small, the short-term economic benefits to the U.S. would be higher if the U.S. served as the host, in comparison to the benefits that could be expected if the U.S. participated in ITER as a full-share non-host. If the U.S. were the host, federal tax revenues could increase by about $\$ 1$ billion over the 30-year project life. If the U.S. were a full-share, non-host participant, a very slight dampening in the U.S. economy could be expected, as expenditures were "leaked" to the host country. In this case, federal tax revenues could decrease by about $\$ 600$ million over the 30-year project life. The minimal short-term economic impacts at the national level are not unexpected. Expenditures on construction, operation, and decommissioning of ITER would be small in comparison to the overall national economy. The impact of these expenditures is minimized further when ITER spending replaces other federal spending that would have occurred without ITER (i.e., when existing federal funds are realigned).

- Visiting Scientist Stimulus. Non-host expenditures in the U.S. (if the U.S. were the host Party) are the primary reason for the positive short-term economic benefits under all conditions examined in the study, except when supplemental funds are assumed to be available. Depending on the exact costsharing arrangements among the host and non-host Parties, the economic stimulus in the host country as a result of visiting scientists could total several billion dollars over the life of the ITER project. Without this stimulus, the net effect of ITER on national employment, for example, would be slightly negative because the ITER expenditures for labor would go to fewer, more highly skilled workers (i.e., ITER workers would be expected to have higher skill and salary levels than those of the average U.S. worker).

- Local/Regional Benefits. The local/regional area that serves as the ITER site in the U.S. will benefit substantially in terms of new employment, personal income, and output. While the benefits are likely to differ from the estimates presented here because of variations in local economies, the average benefits likely to be experienced are significant. The absolute benefits of the ITER project would be less in an area with a smaller economy than in an area with a larger economy because a larger proportion of expenditures would likely be made outside the local area. The relative benefits of the ITER project would be less in large urban areas in comparison to small areas. 
- Local/Regional Employment Impacts. Direct employment at the ITER site (host/non-host workers) during construction, operation, and decommissioning would peak at approximately 4,400, 1,400, and 2,000 workers, respectively. Host workers would make up $52-71 \%$ of all ITER workers during construction and $54 \%$ during operation. Host ITER workers would be solely responsible for decommissioning activities under the reference case. The total employment benefits of ITER in a local/regional area would extend beyond direct employment at the ITER facility. Additional benefits would accrue from "secondary" or indirect employment in the local area. The total employment benefit during peak construction will be on the order of 11,000 new jobs (including visiting scientists), and about 4,000 and 7,000 new jobs each year during operation and decommissioning, respectively.

- Local/Regional Output Impacts. The production of firms and industries at the ITER site would also increase substantially because of direct sales to the ITER facility and purchases by ITER workers. The increase in local area total output would peak at about $\$ 690$ million per year during construction, increase by approximately $\$ 240$ million each year during operation, and climb to more than $\$ 450$ million per year during decommissioning. ITER would create more than $\$ 5$ billion in additional personal income and more than $\$ 10$ billion in new output in the local economy during the life of the project.

- Personal Income Impacts. Personal income at the host site would increase dramatically because of direct wages paid to ITER workers by both host and non-host countries and by the additional wages paid to indirect workers. Local area personal income would increase by more than $\$ 5$ billion over the life of the project, peaking at about $\$ 380$ million per year during construction.

The national results are based on the assumption of full employment in the U.S. economy. When the funding of ITER is based on a realignment of federal funds, the full-employment assumption does not affect ITER impacts because no added labor is required from the economy. However, in the supplemental budget case, expenditures are added to an already fully employed economy. Consequently, labor costs are slightly increased, which in turn causes other changes in the economy. One consequence is that the cost of U.S. products and services increases, which causes U.S. exports to become less competitive and imports to become more attractive. For less than full employment, the impacts of the supplemental budget case would be more positive.

While similar approaches and assumptions were used in both the national and the local/regional analyses, caution should be used in directly comparing the two sets of findings. For example, employment impacts at the national level are, in general, estimated to be smaller than the employment impacts estimated for the typical local/regional area. This difference is partially 
explained by the fact that visiting scientists are included in the employment estimates of the local/regional analysis but are not included in the employment estimates of the national analysis (because of the way the models simulate the economy). The difference is also explained by the supply-response assumptions used in the two sets of models. The full-employment assumptions of the national models imply the transfer of currently employed workers among sectors as ITER is constructed, operated, and decommissioned, thus producing a relatively smaller net employment impact. In contrast, the local/regional analysis assumes that workers from throughout the national labor force are available to fill local/regional ITER-related positions; thus, no offsetting employment losses are experienced in the area surrounding the site. The difference in estimated employment impacts is also partially explained by the fact that the national and local/regional models use different estimation parameters. For example, employment-output ratios at the national level are likely to be different than the employment-output ratios estimated for specific urban economies.

\subsection{QUALITATIVE CONSIDERATIONS}

As discussed in Section 2, this study addresses only a portion of the complex, interrelated set of economic considerations that characterize U.S. participation in ITER. Five specific analysis cases - representing a range of possible budgeting and host/non-host cost-sharing arrangements were examined in detail. Quantitative results for these cases are presented in Section 5 and summarized above.

This section supplements the quantitative results by qualitatively discussing other important economic considerations not formally addressed in the study. The first three considerations deal with issues that would affect the national economic analysis of ITER. The remaining considerations focus on the local/regional level, where ITER impacts are greatest. Like the quantitative indicators used in the study to measure economic benefits (employment, personal income, and output), the additional local/regional considerations are likely to vary in importance, depending on the size and characteristics of the local economy.

- Number of ITER Parties. The number of Parties involved in ITER construction, operation, and decommissioning could be either smaller or larger than the number (four) currently involved in the EDA and assumed in all of the study cases. Such a change would result in different levels of host/nonhost cost sharing and would alter the magnitude of economic impacts. If only three Parties were involved, and the host/non-host cost-sharing assumptions used in the reference case were applied, ${ }^{3}$ the cost responsibilities could change, for example, from 40 to $46 \%$ for the host Party and from 20 to $27 \%$

3 Buildings and structures are supplied by the host; high-technology procurements, design, R\&D during construction, and experiments are shared equally by the Parties; host is responsible for decommissioning. 
for each full-share, non-host Party. While a number of such cost-sharing arrangements are possible, including varying the non-host contributions, the general trends of small positive impacts at the national level and substantial positive impacts at the local/regional level would be expected if the U.S. were host. Similarly, if the U.S. were one of the non-host Parties, the same general national economic trends of small negative impacts would apply.

- Neutral Site. A potentially significant shift in host/non-host, cost-sharing arrangements could occur if a "neutral" country were chosen to hòst ITER. In such a case, it is possible, for example, that the neutral country would incur only the land, site preparation, and building costs, and the ITER Parties would share all remaining costs equally. While the magnitude of national impacts would be different from those for the non-host cases examined in this study, a slight dampening of the economy would be expected because of expenditures outside the U.S. From a negotiating perspective, however, the neutral site approach would tend to equalize the impacts incurred by the ITER Parties.

- Discounting. The analysis described in this study used "undiscounted" constant 1994 U.S. dollars. This approach allows a year-to-year comparison of ITER expenditures and impacts under alternative conditions, such as funding sources. In some circumstances, it would be appropriate to "discount" future expenditures and impacts to "present-value" terms, so that the time value of money is taken into account. This case would occur if alternative technology development strategies were being analyzed. In such a case, the long-term benefits of commercial fusion power would be critical, as would the expenditure profile and long-term benefits of the alternative technologies. The present study, however, examines a single technology and thus focuses on the short-term economic impacts of the ITER project. In particular, cash outlays for construction, operation, and decommissioning are treated as flows of expenditures in the future years in which they are spent. Discounting future expenditures would provide an estimate of their net present value to society but would not alter the relative share of life-cycle costs among participating Parties.

- Industry Agglomeration Effects. The effects of industry agglomeration would occur as new industries or service firms moved into the area surrounding the ITER site to take advantage of proximity to the project. Some might supply materials, services, or equipment for one or more phases of the project. Others might be attracted to the area by spin-off activities - either directly from the project or indirectly from the manufacture of equipment supplied to the 
project. In either case, these activities will (1) bring additional hightechnology industry to the area, (2) increase the level of skills in the local labor force, (3) contribute to the area's economic diversification, and (4) increase the area's competitiveness by creating additional markets for local products in new geographic areas. Smaller localities are likely to reap greater benefits from any agglomeration effects. Areas with smaller economies tend to specialize in fewer products and be less competitive with larger areas.

- Offsetting Impacts. Construction, operation, and decommissioning of ITER may have some negative effects on existing economic activity in the local economy. The model used in this study assumes that the local economy has unlimited excess capacity. In effect, this assumption means that materials and workers can be supplied to the ITER project without decreasing the activities of other firms. For example, workers leaving one firm for higher paying employment at the ITER site can be easily replaced by the previous employer. In reality, local economic capacity is not unlimited. Some firms in the local/regional area will find their output decreased or their inputs more difficult (or expensive) to assemble because ITER is redirecting resources within the local economy.

- Replacement of Lagging or Lost Activities. Local industries may have suffered a declining market share in some locations that might be chosen as the ITER site. Local expenditures on ITER may significantly stimulate producers in various manufacturing and service sectors, including those suffering from declining market share on a national basis. It is also possible that ITER could be placed in an area that has suffered a recent economic loss. Although it is not possible to predict exactly how the project might affect declining sectors in a local area when the exact location is unknown, it is likely that the relative impact will be larger in smaller metropolitan areas.

- Impacts on Local Government Services and Financial Resources. Increased economic activities in an area will contribute to a larger local tax base. In areas with larger existing economies, such an increase will likely lead to increased public services. In local areas with smaller economies, new services may be required along with an increase in existing public services. The costs of public services will likely rise because of ITER activities. Because of the relative magnitude of ITER in smaller economies (particularly during construction), many of the additional jobs created will.be taken by in-migrants or new workers to the area. This influx of new residents is likely to disrupt the area considerably because local governments will be required to provide additional infrastructure and public services. The temporary residence of many 
of the in-migrants, especially during construction and decommissioning, can create short-term problems for local governments. Local authorities will have to raise additional revenues to cover the necessary expenditures for temporary in-migrants and thus place financial burdens on existing and new permanent workers.

- Impacts on Local Costs of Living. The addition of ITER to the local/regional economy will tend to put pressure on the local cost of living. As noted previously, the model used in this study assumes that the local economy has unlimited excess capacity. Under this assumption, wages do not change as local employment increases. In reality, however, wages will rise as the demand for labor in the local economy increases. In addition, new in-migrants will increase the demand for housing, shopping, and so forth. The combined effect of higher incomes and increased population will be upward pressure on the local cost of living. The impact of project expenditures on local inflation is likely to be greatest in smaller areas.

- Tourism Potential. The status of the ITER facility, along with the potential of fusion as a major alternative source of energy for the future, may be a factor in drawing tourist expenditures to the local area. Tourism could lead to additional local employment, income, and output.

- Cultural Diversity. The entire life cycle of the ITER project could introduce professionals and their families from other countries into the culture of the local area. In most cases, cultural diversity is thought to add to the "richness" of local community traditions and customs.

\subsection{CONCLUDING OBSERVATIONS}

On the basis of the study results and discussions with members of the ITER Steering Committee - U.S. (ISCUS), the U.S. ITER Industry Council, and the U.S. ITER Home Team, the economic study team formulated specific observations about ITER, the long-term benefits of U.S. host/non-host participation in the ITER program, and related issues. These observations are presented below.

- U.S. Participation in ITER. The motivation for U.S. participation in ITER either as a host or non-host Party - cannot be based on the short-term economic benefits derived from funds expended on the ITER project. Rather, the fundamental motivation for supporting ITER rests on future economic and environmental conditions; the potential for commercial fusion energy; and the 
role ITER can play in moving toward the goal of safe, economical, and environmentally acceptable commercial fusion power. The short-term economic benefits from participation in ITER - as described in this report are only a part of the overall calculus that must be employed when considering the merits and direction of U.S. participation in the ITER program.

- Hosting Versus Non-Hosting Considerations. A comprehensive comparison of all the benefits of hosting or not hosting ITER could include a variety of factors. These include site selection and NEPA/EIS costs; the likelihood that service, supply, and spin-off companies might spring up near the ITER site; national prestige and the U.S. image as a leader in high-technology development; the relative ease of supporting U.S. industry interest in fusion; the likelihood of technology transfer to U.S. industry; and the relative impacts on the U.S. fusion scientific and engineering infrastructure, the broader U.S. scientific and engineering educational infrastructures, and the U.S. hightechnology infrastructure.

- Benefits of Hosting ITER. If the U.S. were to host ITER, significant positive benefits would likely occur in some or all of the aforementioned areas. For example, positive benefits are likely because U.S. industry would have ready access to the site for interaction with the ITER team; the U.S. could gain experience in and establish precedents for regulating and licensing fusion facilities; ITER would support educational and cultural activities in the economy of the community; non-host expenditures in the U.S. would lead to the short-term benefits identified in the study; the position of the U.S. as a leader in technology would be enhanced; and the U.S. fusion program scientific and engineering infrastructure, as well as the broader U.S. scientific/technical and educational infrastructures, would be enhanced. However, the magnitude of such potential benefits clearly depends on the cost- and technology-sharing arrangements among the host and non-host Parties.

- Participating in ITER as a Non-Host. The U.S. would benefit to a similar degree as a non-host participant in ITER. For example, scientific and engineering information would be shared, and U.S. fusion-related industries would gain $\mathrm{R} \& \mathrm{D}$, construction, and operational experience.

- Benefits of Joint Participation. Significant savings can be gained by joint cooperation in the ITER program. Without such cooperation, the cost of construction, operation, and decommissioning to a single Party would be approximately $\$ 20$ billion. Hosting ITER could reduce this life-cycle cost to 
a single Party to approximately $\$ 8$ billion (reference case), while preserving the overall level of expected benefit. While the benefits to the national economy are minimal in the short term, benefits to local regions and future generations could be significant. A further reduction in life-cycle cost to about $\$ 4$ billion (reference case) is possible if the U.S. were one of three full-share non-host participants. Additionally, the pooling and sharing of knowledge and technological expertise are other major benefits of international cooperation on ITER. Each Party has decades of experience in fusion research, and each brings particular technical strengths to the joint effort.

- Trade-offs and Value Judgments. Hosting ITER would result in a small increase in national income for the host country and a small decrease in national income among non-host participating countries. When taking into account the adjustments for national income changes, the host versus non-host financial differences in the reference case (i.e., project expenditures plus or minus tax revenues) are close to breakeven. Difficult trade-offs, however, must be made in deciding whether to be the host or a non-host Party. Multiple conflicting objectives are clearly involved. For example, in addition to the many factors and considerations discussed previously (e.g., agglomeration effects, national prestige, spin-off and technology transfer opportunities), it is likely that each Party would want to (1) maximize its involvement in the project, thereby gaining the maximum amount of hands-on experience and knowledge; (2) maximize cost sharing (i.e., minimize its financial obligations); (3) minimize expenditures that "leak" outside its borders, a particularly important consideration for the non-host Parties; and (4) postpone expenditures as far as possible into the future to take advantage of the effects of the time value of money. The relevance and relative importance of such objectives are value issues that only policy and decision makers can resolve. 


\section{REFERENCES}

BEA, 1994, "Benchmark Input-Output Accounts for the U.S. Economy, 1987," Survey of Current Business, pp. 73-115 (April).

DOE, 1993a, International Thermonuclear Experimental Reactor, DOE/ER-ITER-0004, U.S. Department of Energy, Washington, D.C.

DOE, 1993b, The U.S. Fusion Program as a Source of Technology Transfer, U.S. Department of Energy, Office of Fusion Energy, Washington, D.C. (Sept.).

DOE, 1994, Interim Report to the Congress on Planning for International Thermonuclear Reactor Siting and Construction Decisions, U.S. Department of Energy, Washington, D.C. (Nov. 21).

FPA, 1993, Fusion Energy, Fusion Power Associates, 2 Professional Drive, Suite 248, Gaithersburg, Md. (April).

Hanson, D.A., 1994, "Application of the AMIGA Model for Analyzing Policies to Reduce Greenhouse Gas Emissions," Proceedings of the Air and Waste Management Association Specialty Conference on Global Climate Change, Phoenix, Ariz. (April).

IAEA, 1990, Preliminary ITER Cost and Schedule Estimates, ITER Documentation Series No. 14, International Atomic Energy Agency, Vienna, Austria (Aug.).

IAEA, 1991, ITER Conceptual Design Activities Report, ITER Documentation Series No. 16, International Atomic Energy Agency, Vienna, Austria (Aug.).

IMPLAN, 1994, Micro IMPLAN User's Guide, Version 91-F, Stillwater, Minn. (March).

McCarthy, M., 1991, "LIFT: INFORUM's Model of the U.S. Economy," Economic System Research 3(1):15-36.

TAC-4, 1994, "Detail of the ITER Outline Design Report, Vols. I-III," prepared for the Fourth Meeting of the ITER Technical Advisory Committee, San Diego Joint Work Site, San Diego, Calif., Jan. 10-12.

Temple, L.E., and J.N. Doggett, 1994, Estimate of Engineering Design Costs for the International Thermonuclear Experimental Reactor, Design Effort Task Group Report ITER/US/94/EN-EM-01, Argonne National Laboratory, Argonne, Ill. (March 31). 
APPENDIX A:

THE INTERNATIONAL THERMONUCLEAR EXPERIMENTAL REACTOR PROGRAM: TECHNOLOGY AND ORGANIZATION 


\section{APPENDIX A: \\ THE INTERNATIONAL THERMONUCLEAR EXPERIMENTAL REACTOR PROGRAM: TECHNOLOGY AND ORGANIZATION}

\section{A.1 INTRODUCTION}

The magnetic fusion energy facilities, operating and proposed, that are currently anticipated to be needed to reach the goal of having a demonstration magnetic fusion power plant operating by about 2025 are shown in Figure 1 of the main text. ${ }^{1}$ As indicated, the International Thermonuclear Experimental Reactor (ITER) is an integral part of this overall plan. In particular, ITER is a multiphase effort by the international community to demonstrate the scientific and technical feasibility of magnetic fusion energy. One of the main objectives of the ITER program is to demonstrate controlled ignition and extended plasma burn; however, the ultimate goal is steady-state operation. Other objectives include demonstrating the technologies needed to achieve fusion energy and serving as an integrated test bed for high-heat-flux and other components required for the practical use of fusion energy.

The other facilities shown in Figure 1 are designed to address issues associated with advanced materials development, fusion power technology, and tokamak concept optimization. ${ }^{1} \mathrm{~A}$ materials test facility, which would closely simulate the environment in a fusion power plant for the testing of advanced materials, and a blanket test facility, which would allow candidate blanket designs to be tested at power-plant-relevant conditions for long, continuous time periods, are shown. (Like ITER, both projects are being explored as part of international cooperative efforts, and no decisions have been made to commit to construction of these facilities.) The proposed Tokamak Physics Experiment ${ }^{2}$ (TPX), which would be a follow-on to the Tokamak Fusion Test Reactor, would allow verification of advanced physics concepts by providing steady-state operation over extended periods (up to approximately 15 minutes). The area identified as supporting physics and enabling technology development includes work in superconducting magnet systems, fueling systems, helium exhaust systems, control systems, and robotics. As indicated, these supporting technology developments are focused on ITER and TPX.

1 Although relevant at the time of the study, Figure 1 no longer accurately represents the scope of the present U.S. fusion energy program.

2 The proposed TPX project has been cancelled. 


\section{A.2 MAGNETIC FUSION ENERGY}

Fusion is the process by which the sun and other stars produce energy. Combining (fusing) two light atoms such as hydrogen into a heavier atom results in the release of excess energy. For example, a fusion reaction of two isotopes of hydrogen (deuterium and tritium) into an isotope of helium and a neutron produces a total energy release of 17.6 million electron volts. To put this into perspective, the fusion energy released from one gram of deuterium-tritium fuel equals the energy from about 2,400 gallons of oil.

On earth, fusion reactions can occur only under carefully engineered conditions. Most fusion researchers use strong magnetic fields to contain an extremely hot plasma of light atoms. The challenge to scientists is to (1) hold the fast-moving particles together long enough for fusion reactions to occur and (2) ensure that sufficient numbers of these reactions are available to produce useful energy.

At present, major fusion experiments confine the plasma within a doughnut-shaped device called a tokamak. To do so, the tokamak uses three types of magnets:

- Toroidal field magnets, which create a "container" for the plasma;

- Poloidal field magnets, which keep the plasma centered and stable; and

- Central solenoid magnets, which induce an electric current in the plasma.

As a potential future energy resource, magnetic fusion could provide large amounts of electricity for world use. It is an attractive option because its fuel is virtually inexhaustible, and unlike fossil fuels, it will not produce undesirable combustion products that damage air quality and contribute to global environmental problems (e.g., "greenhouse" gases and acid rain).

\section{A.3 ITER TOKAMAK}

ITER is based on the tokamak concept, but the device will be significantly larger than existing fusion experiments. It will be about 30 meters high, that is, about as tall as a nine-story building (Figure A.1). The plasma chamber will have a noncircular cross section. The ITER tokamak will generate approximately $1,500 \mathrm{MW}$ (thermal) of power and operate with pulses with a flat-top duration of about 1,000 seconds. The ITER program will also aim for a demonstration of steady-state operation in reactor-relevant plasmas. 


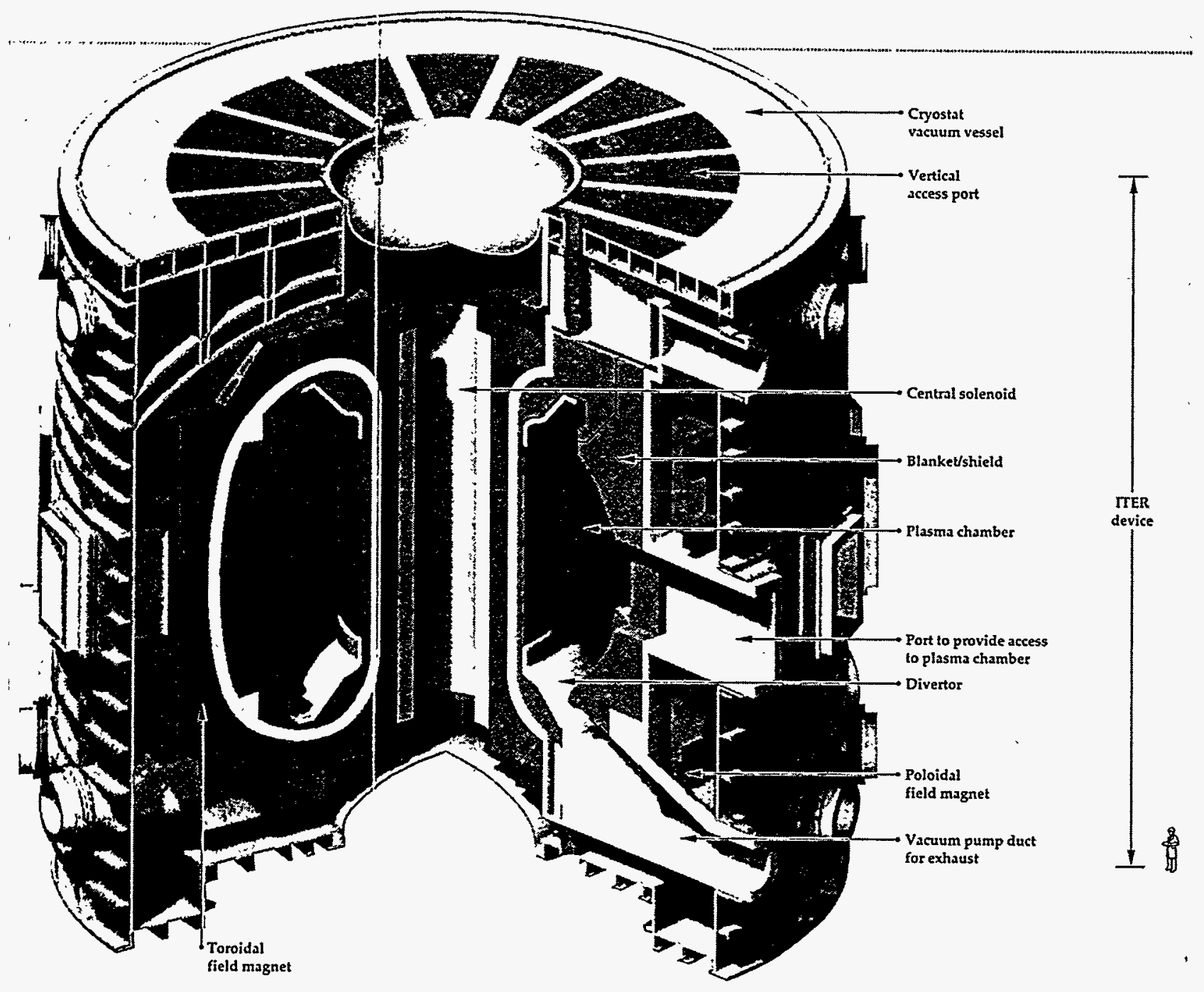

FIGURE A.1 Computer-Generated Model of the ITER Device

\section{A.3.1 Basic Components}

The basic components of the ITER tokamak are as follows:

- Superconducting magnets. Expected to be the largest superconducting magnets to date, these magnets represent a key technology that requires further development. The toroidal coils will produce a magnetic field of about 11 to 13 teslas at the magnet windings.

- Divertor. This component will control impurities and provide exhaust for the helium ash. A special design challenge will be selecting the proper physics 
operating mode and the materials for the divertor surfaces and the "first wall" that lines the plasma chamber.

- Fuel. Fuel for ITER will consist of a combination of deuterium and tritium. Much of the tritium may be produced in breeding blankets, which are layers of lithium-containing materials inside the vacuum vessel.

Because remote maintenance tools and techniques will be needed for ITER, the design and arrangement of the major systems and components must accommodate this requirement. Strategically placed ports will allow access to the interior of the machine.

\section{A.3.2 Safety Considerations}

Safety is an integral part of the ITER design. Passive safety features will be incorporated into the design wherever possible.

The ITER machine will also be designed to demonstrate the safety and environmental potential of fusion power. For example, low-activation materials are to be tested in ITER to obtain an experience base for the potential use of such materials in future fusion devices.

\section{A.4 FUTURE ITER OPERATIONS}

The ITER device could be in operation as early as 2007 , as assumed in the report. Phase 1 will address the issues of controlled ignition, extended burn, and steady-state operation. Phase 2 will emphasize improving overall performance and conducting a component testing program, including testing of blanket modules. ITER will embody all of the essential features of the heat-generating core for a fusion power plant.

\section{A.5 ITER ORGANIZATION}

\section{A.5.1 Background}

To make the ITER tokamak a reality, four international Parties - the European Union, Japan, Russia, and the U.S. - are working together (ITER 1994a,b). The ITER Council is responsible for the overall direction of the program. The Director, who is assisted by a Deputy Director from each Party, heads the Joint Central Team (JCT). The four Parties provide personnel to the JCT in approximately equal numbers. 
Each Party has established a "Home Team" that performs tasks assigned by the Director. All of the research and development (R\&D) tasks are carried out in the national programs. The JCT then integrates all of the national programs of the four Parties.

The work performed by the JCT is accomplished at three co-centers at the following locations:

- San Diego, California, which is project headquarters and the site for design integration and work on safety, buildings, and physics;

- Garching, Germany, which is the site for work on in-vessel components and related systems; and

- Naka, Japan, which is the site focusing on ex-vessel components and related systems.

\section{A.5.2 U.S. Home Team}

The U.S. Home Team coordinates all domestic work on ITER. The team performs the design tasks and the R\&D tasks assigned by the Director and also provides personnel for the JCT. The DOE Office of Fusion Energy sponsors all U.S. work on ITER.

The U.S. fusion community supports the Home Team through its continuing work in the area of fusion energy. Senior individuals, representing a broad spectrum of the U.S. fusion community, form the ITER Steering Committee. This committee advises the Home Team about scientific and technical matters.

\section{A.5.3 Role of U.S. Industry}

A major thrust of the Home Team is to prepare U.S. industry to bid successfully on the construction of ITER. Key aspects of the domestic work will be performed by U.S. industries and businesses.

Industry teams have been formed in all of the key technology areas. In addition, the U.S. Industry Council advises the Home Team on policy issues related to industry participation in the ITER program. 


\section{A.6 BENEFITS OF COLLABORATION}

The ITER program represents an unparalleled example of international collaboration on a major scientific project. From the beginning, the four Parties have cooperated and contributed equally.

Sharing of costs and benefits is the fundamental principle of the collaboration. The pooling and sharing of knowledge and technological expertise are also major benefits. Each of the Parties has decades of experience in fusion research, and each brings specific strengths to the joint effort.

\section{A.7 APPENDIX A REFERENCES}

DOE, 1993, International Thermonuclear Experimental Reactor, DOE/ER-ITER-0004, U.S. Department of Energy, Washington, D.C.

ITER, 1994a, ITER EDA JCT Backgrounder, International Thermonuclear Experimental Reactor Engineering Design Activities, Joint Central Team, External Relations Office, San Diego, Calif. (May 17).

ITER, 1994b, ITER, EDA JCT Fact Sheet, International Thermonuclear Experimental Reactor Engineering Design Activities, Joint Central Team, External Relations Office, San Diego, Calif. (May 19). 
APPENDIX B:

LIFT MODEL DESCRIPTION 


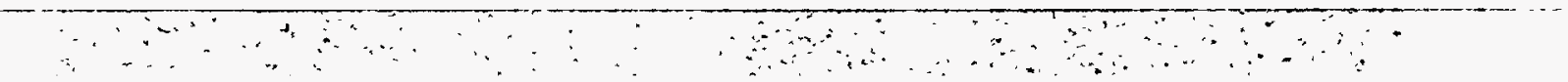




\section{APPENDIX B:}

\section{LIFT MODEL DESCRIPTION}

The Long-Term Interindustry Forecasting Tool (LIFT), developed by the Interindustry Forecasting Project of the University of Maryland (INFORUM), is a national interindustry model capable of modeling industry relationships as well as macroeconomic behavior, such as impacts on the unemployment rate and the balance of payments. LIFT is a macroeconomic model in that it determines all the variables usually considered in macroeconomics (income, savings, employment, unemployment, inflation, interest rates), but it differs from other macroeconomic models in that industry detail is central to its structure and causation.

LIFT comprises three main components:

- The real side, which estimates final demands, output by producing sector, and labor requirements;

- The price-income side, which estimates both the components of gross product originated by industry (value added) and unit prices by product; and

- The accountant, which closes the model with respect to income, determines the economic aggregates, and estimates transactions that have not been calculated elsewhere in the model.

The components run iteratively until the model converges on a solution.

In the real side of LIFT, equations for final demands are evaluated, and production and labor requirements are calculated for 85 producing sectors. Government purchases are exogenous; other components of final demand are determined by behavioral equations. Personal consumption equations have been estimated for nearly 80 categories of expenditures by using relative prices, real income, and demographic variables. Equipment investment equations have been estimated for 55 industries; these depend on changes in industry outputs and relative prices of capital, labor, and energy. Construction is determined for 31 categories of structures. The INFORUM International System (an international family of interindustry models) contributes product-specific explanatory variables for foreign trade. Exports by product are a function of foreign demands for imports and relative prices, which incorporate exchange rate movements. Imports by product are a function of product-specific domestic demand and relative foreign-to-domestic prices.

LIFT iteratively solves a series of input-output equations to determine output. Because current output, imports, and inventory change depend on each other, three sets of equations are 
solved together. (Another iterative loop uses equipment and construction investment in determining output). Labor productivity (output per hour) for 85 sectors is estimated as a function of trends and changes in output. The equations recognize that the influence of output is not symmetric over the business cycle. Employment is determined by labor productivity, output, and the length of the work year.

The real side of LIFT is defined in terms of products: final demands are demands on products. Price statistics measure the prices of products. However, statistics on the factors of production - labor income, capital income, and indirect taxes - reflect the organization of firms. Therefore, to translate between the product classification on the real side and the industry classification on the income side, a "product-to-industry" bridge has been constructed. This bridge is similar to the "make table," which identifies the industry in which products are made. The product-to-industry bridge translates value added between the product and its industry classification, and vice versa. When an indicator of real activity is needed to determine gross product, the bridge is used to produce "constant-price, value-added, weight output." Alternatively, when nominal gross product has been determined by industry, the bridge is used to translate it into the estimate of value added by product.

Labor compensation is determined by hours (from the real side) and equations for average hourly compensation ("wage" rates). Corporate profits and proprietor income, by industry, are functions of material and labor costs and various measures of economic activity (growth in output, changes in unemployment, etc.) Net interest payments are a function of interest rates. Interest rates are influenced by the rate of economic growth, rate of inflation, and monetary tightness. (On the real side, these factors influence investment activity.) Other equations determine the remaining components of capital income: capital consumption allowances, inventory valuation adjustments, subsidies, and business transfer payments. Indirect business taxes (sales, property, and excise taxes) are the other component of gross product by industry.

The accountant compiles the aggregate national account tables by summing up the sectoral detail for final demands and income by industry. It determines total value added by category and converts this information into personal income. It also determines nominal gross domestic product by applying estimated unit prices to the real (constant dollar) estimates of final demand. The accountant constructs personal income as the sum of labor income, proprietor income, and dividends (from the income side), interest income from business and government, and transfer payments from government and business. Taxes are removed from personal income to yield disposable income. When deflated, disposable income becomes real disposable income, the variable used to explain the real side's personal consumption expenditures. The accountant also calculates the savings rate, which is a function of the unemployment rate, the percentage change in income, automobile purchases as a share of personal consumption expenditures, interest payments as a share of income, personal contributions to social insurance as a share of income, and inflation. 
A key feature in the stability of the model is the role of the unemployment rate in several equations. As economic activity slackens, the savings rate falls. Thus, consumers spend a larger share of their income and help stimulate demand. On the price side, an increasing unemployment rate moderates increases in several components of income by industry (wage rates and profits), thus moderating inflation and maintaining the level of real income.

\section{APPENDIX B BIBLIOGRAPHY}

Almon, C., et al., 1974, 1985: Interindustry Forecasts of the American Economy, D.C. Heath \& Company, Lexington, Mass.

Almon, C., and A. Barbera, 1980, "Investment in Producer Durable Equipment, 1976-1990," in Capital, Efficiency and Growth, G.M. Von Furstenberg (editor), Ballinger Publishing Company.

Almon, C., and D. Nyhus, 1980, "The INFORUM International System of Input-Output Models and Bilateral Trade Flows," in Input-Output Approaches in Global Modeling, G. Bruckmann (editor), Pergamon Press, Elmsford, N.Y.

Almon, C., 1991, "The INFORUM Approach to Interindustry Modeling," Economic Systems Research 3(1):1-8.

Almon, C., et al., 1991, "Simulation of a Mexico-USA Free Trade Agreement," Economic Systems Research 3(1):93-97.

McCarthy, M., 1991, "LIFT: INFORUM's Model of the U.S. Economy," Economic System Research 3(1):15-36.

Meade, D., et al., 1986, "Tax Simplification and the Long-Run Performance of the U.S. Economy," Journal of Policy Modeling (Nov.).

Monaco, R., and J. Phelps, 1995, "Macroeconomic Implications of Health Care Cost Containment," in Proceedings of the Society for Computer Simulation. 


\section{APPENDIX C:}

\section{AMIGA MODEL DESCRIPTION}




\section{APPENDIX C:}

\section{AMIGA MODEL DESCRIPTION}

The Argonne Multisector Industry Growth Assessment Model (AMIGA) is a comprehensive model of the U.S. economy with the "bottom up" property that the sum of the activities in individual sectors equals gross domestic product (GDP) (Hanson 1994a, 1994b; Hanson and Camp 1995). AMIGA can be classified as a multisector, multiperiod computable general equilibrium model with a consistently embedded input-output coefficient matrix. AMIGA converges to a general equilibrium solution, integrating five major modules: (1) demand for goods and services, (2) sectoral production and employment, (3) national income accounts, (4) costs and pricing of commodities, and (5) labor market response (Figure C.1) Some AMIGA outputs are by sector and some are aggregate economy-wide indices, such as GDP, total employment, and the balance of trade. The sectors are based on the 1987 benchmark input-output accounts (BEA 1994).

The AMIGA model focuses on materials, manufactured goods, energy demand, and energy conservation measures. It has a unique ability to calculate the benefits of improvements in energy efficiency. Such improvements lower costs, lower industry pricing, and increase the desired output of production. The AMIGA model represents four types of effects:

- Input-output analysis, which solves for sector outputs given the vector of final demands;

- Induced or income effects, which cause changes in final demands;

- Macroeconomic effects, which include labor market adjustments and crowding out among sectors; and

- Efficiency effects, which are cost and price changes that cause shifts in the mix of goods and services demanded.

AMIGA represents domestic final demands, exports, imports, intermediate demands, sector outputs, and employment for more than 200 sectors of the economy. Supply equals demand (i.e., commodity balances are satisfied) in each sector. The material, energy, and labor inputs each sector requires to produce a unit of output are based on the input-output data. AMIGA determines costs on the basis of the same input-output coefficients used to calculate intermediate demands. That is, costs are the dual of sector outputs. Pricing is based on the profit-maximizing behavior of firms that face cost and demand functions. 


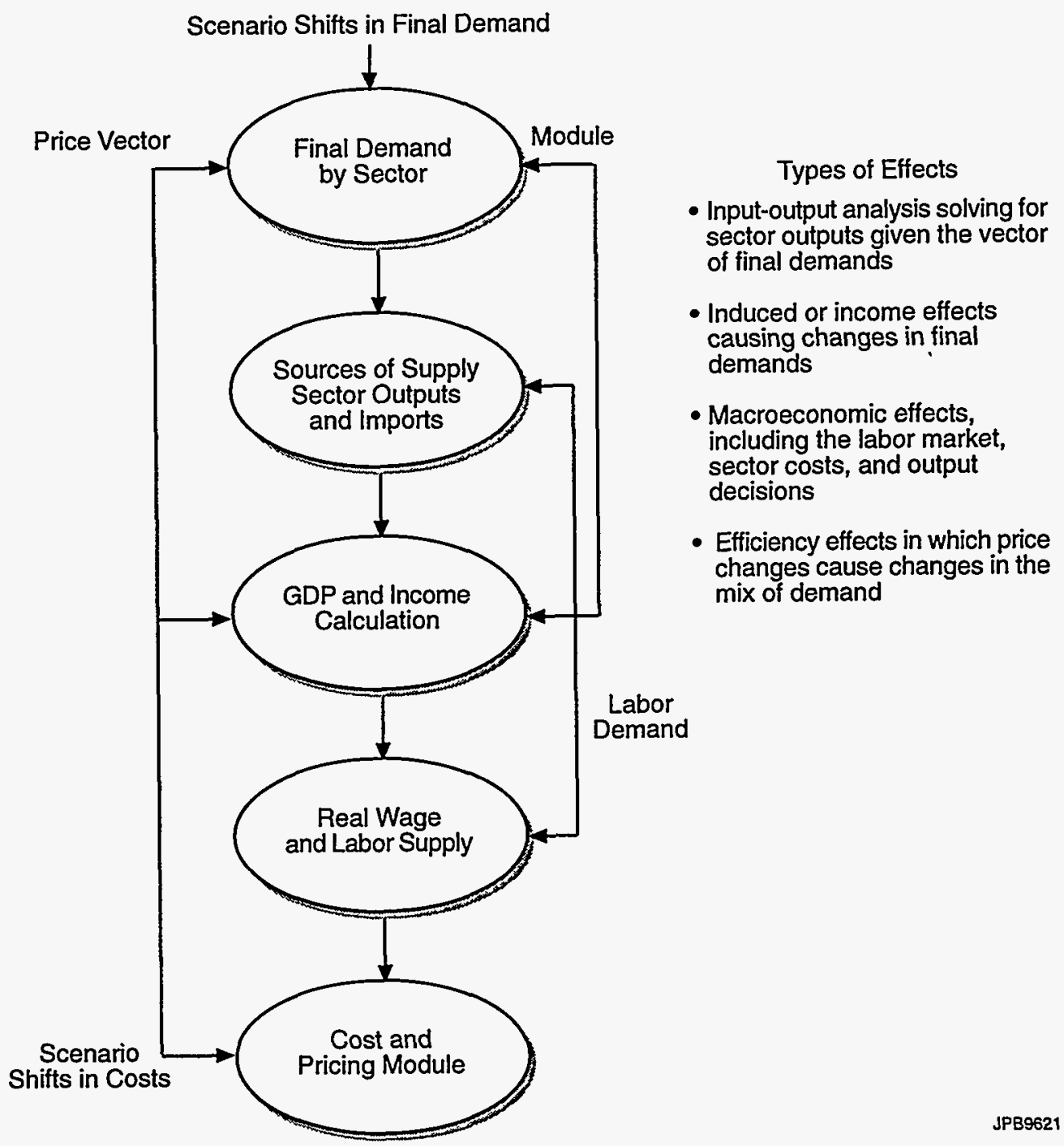

\section{FIGURE C.1 Economic Effects Represented by the AMIGA Model}

AMIGA is coded in C language in a flexible modular structure. Special-purpose sectors can easily be added, and the technical coefficients of existing sectors can be scaled. New technologies can be characterized in terms of the sector inputs they require for production. Special sectors were added to AMIGA to examine the economic impacts of the International Thermonuclear Experimental Reactor (ITER):

- ITER specialty electrical machinery and equipment,

- Superconducting wire manufacturing,

- Importing of niobium ore for the superconducting wire, and

- Special host construction labor. 
AMIGA implements Milton Friedman's permanent income hypothesis. Changes in income over time give rise to changes in expenditures on goods and services. Demand for commodities (AMIGA represents more than 200) is determined by demand functions that depend on relative prices. For example, as energy prices increase, perhaps because of an energy tax policy, final commodities that embody more energy will have higher relative prices and tend to lose market share relative to other, less energy-intensive goods and services.

On the demand side, AMIGA shows the full general equilibrium effects of improvements in energy efficiency. If households use less energy, more disposable income will be available to spend on other goods and services. If industry becomes more efficient in energy use per unit of output, it can offer lower prices for the goods it sells - either final goods or semifinished goods sold to other producers, which will indirectly lower the costs for their products. Energy efficiency reduces a firm's variable costs. Firms in markets facing downward sloping demand curves (i.e., those that sell in differentiated product markets) have an incentive to increase output and lower their prices when costs shift down. The increased desired output of domestic manufacturers, and their lower relative prices, tends to increase exports and decrease imports.

AMIGA mitigates exogenous demand or cost stimulus effects by increases in labor costs and interest rates, which reduces, but does not totally offset, the original source of change. Hence, some sectors may be crowded out. On the supply side, AMIGA represents construction projects for investment in new plants and equipment, including energy supply investment.

AMIGA models the supply and demand for fuels and electricity and the greenhouse gas emissions from those fuels. Because AMIGA is a general equilibrium model, it can be viewed as representing the total life cycle or fuel cycle. The impacts on all relevant sectors are shown, including net changes in fuel consumption and resulting emissions. The fuel demand sectors are individual industries, households, government, other commercial activities, freight transportation, personal transportation, and utilities. For each fuel, AMIGA models fuel price, physical quantities, and expenditures. International trade in fuels is included.

\section{APPENDIX C REFERENCES}

BEA, 1994, "Benchmark Input-Output Accounts for the U.S. Economy, 1987," Survey of Current Business, pp. 73-115 (April).

Hanson, D.A., 1994a, "Application of the AMIGA Model for Analyzing Policies to Reduce Greenhouse Gas Emissions," Proceedings of the Air and Waste Management Association Specialty Conference on Global Climate Change, Phoenix, Ariz. (April). 
Hanson, D.A., 1994b, "The Effects of Environmental Policy and Clean Up Expenditures in the Economy," presented at the 87th Annual Meeting of the Air and Waste Management Association, Cincinnati, Ohio (June).

Hanson, D.A., and J.S. Camp, 1995, "Application of the AMIGA Model for Understanding the Economic Impacts of Biomass Fuels," presented at the Workshop on Economic Impacts of Biomass Fuels, Argonne National Laboratory, Argonne, Ill. (April). 
APPENDIX D:

IMPLAN MODEL DESCRIPTION

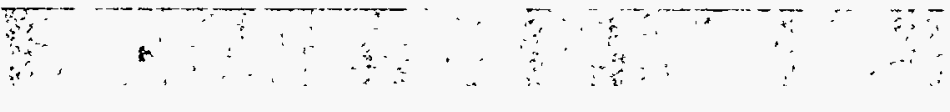




\section{APPENDIX D:}

\section{IMPLAN MODEL DESCRIPTION}

The Impact Analysis for Planning (IMPLAN) model is a microcomputer-based program that provides the algorithms for construction of regional input-output models for areas as small as a county and aggregation of individual county databases for multicounty analysis. IMPLAN was originally developed for the U.S. Department of Agriculture and is maintained and supported by the Minnesota IMPLAN Group, Inc., Stillwater, Minnesota.

The components of the IMPLAN database form the economic accounts of an individual county or several counties. These accounts show the flow of commodities to industries and institutional consumers in 528 separate industries in agriculture, mining, construction, manufacturing, wholesale and retail trade, utilities, finance, insurance and real estate, and consumer and business services. Each industry is described in terms of its purchases from and sales to all other industries in the local economy. Values for all activities are in producers' prices and do not include transportation costs or other additional transaction costs associated with delivering outputs from each industry to other intermediate users.

The accounts also provide information on value added by each industry and sales by each industry to final demand. Value added has four main components: employee compensation (wages, salaries, benefits, life insurance, retirement, etc.), proprietary income (payments received by selfemployed individuals as income), other property-type income (payments received from royalties and dividends), and indirect business taxes (primarily excise and sales taxes individuals pay to businesses).

Final demands are goods and services purchased for their ultimate use by an end user. They include personal consumption expenditures (payments by individuals or households to industries for goods and services for personal consumption); federal government purchases (military and nonmilitary) and sales; state and local government purchases (public education and noneducation) and sales; inventory purchases (unsold annual output) and sales (where inventory reduction exceeds additions from production); capital formation (expenditures to obtain capital equipment); and foreign exports. Final demands are allocated to producing industries, and margins are allocated to the service sectors (transportation, wholesale and retail trade, insurance, etc.) associated with providing that good to the final user.

The IMPLAN model provides the necessary information to estimate a complete set of regional economic accounts for a local area. The economic accounts are then converted to industry through the use of input-output accounts and a set of Leontief multipliers. The initial data set is the "use" of commodities by industry and the "make" of commodities by industry. These flows are 
derived for the local area from the national input-output accounts. Final demands, value added, output, and employment are derived for each data set. Employment numbers are also derived for each industry in the local area.

To create a regional input-output model for the local area, the regional data are combined with the 1982 national structural matrices produced by the Bureau of Economic Analysis. This operation produces regional structural matrices and eliminates industries that do not exist in the region. Imports are then estimated via the calculation of regional purchase coefficients (RPCs). An $\mathrm{RPC}$ represents the proportion of the total locally produced supply of a good or service required to meet a particular industry's intermediate and final demands; RPCs range between 0 and 1 . In the IMPLAN model, RPCs are derived from the 1977 Multi-Regional Input-Output Accounts, a crosssectional database of input-output accounts linked with consistent interstate trade flows. Imports are calculated by using the minimum of the RPC or the supply/demand pool. The regional final demands and the use matrix are then multiplied by the resulting RPC coefficients, which creates a set of matrices and final demands that are free of imports. Domestic exports are the residual of regional production not locally consumed. The result is a balanced set of regional economic accounts.

The input-output accounts are then developed. The regional use matrix and final demands are converted from a commodity basis to an industry basis by using the market share hypothesis. The subsequent inversion of the input-output accounts provides an import-free Leontief matrix of multipliers.

The notion of a multiplier rests on the difference between the initial effect of a change in demand and the total effect of that change. Total effects can be calculated either as direct and indirect effects or as direct, indirect, and induced effects. Direct effects are production changes associated with the immediate effects or final demand changes. Indirect effects are production changes in backward-linked industries caused by the changing input needs of directly affected industries (i.e., additional purchases to produce additional output). Induced effects are changes in regional household spending patterns caused by changes in household income generated by the direct and indirect effects.

IMPLAN estimates five sets of multipliers, corresponding to five measures of regional economic activity: total industry output, personal income, total income, value added, and employment. These multipliers are used to estimate the impact of changes in expenditures in an industry that provides inputs to a particular existing or new activity. 


\section{APPENDIX E:}

\section{LIFE-CYCLE COST CHARACTERIZATION DATA}




\section{APPENDIX E: \\ LIFE-CYCLE COST CHARACTERIZATION DATA}

This appendix documents the life-cycle cost characterization data that underlie the national and local/regional economic analyses. The data are presented in a series of linked spreadsheets developed with Microsoft Excel. Cost data for the reference, magnet option, and increased non-host participation cases are presented. (The S\&T budget realignment and supplemental budget cases, which examine the importance of the assumption about the source of federal funding for U.S. participation in the International Thermonuclear Experimental Reactor [ITER], use the reference-case cost data.) The reference life-cycle cost data summarized in Table 2 (Section 4.3.5) provide the baseline for the cost breakdown analysis presented in the spreadsheets. The expenditure profiles presented in Section 4.4 and summarized in Table 3 for construction activities are used in all cases.

Tables E.1 through E.11 document the reference case life-cycle cost characterization data. Tables E.12 through E.20 document the magnet option case. Finally, Tables E.21 through E.28 document the increased non-host participation case. 
TABLE E.1 Host/Non-Host Funding and Spending Assumptions: Reference Case

\begin{tabular}{|c|c|c|c|c|c|c|}
\hline \multirow[b]{2}{*}{ Cost Category } & \multirow[b]{2}{*}{$\begin{array}{c}\% \text { Host } \\
\text { Cost }\end{array}$} & \multicolumn{3}{|c|}{$\%$ Non-Host Cost (Each Party) } & \multirow[b]{2}{*}{$\begin{array}{c}\text { Total } \% \\
\text { Non-Host } \\
\text { Cost }\end{array}$} & \multirow[b]{2}{*}{ Total \% } \\
\hline & & $\begin{array}{l}\text { At Host } \\
\text { Site }\end{array}$ & $\begin{array}{c}\text { At } \\
\text { Home }\end{array}$ & Total & & \\
\hline \multicolumn{7}{|l|}{ Construction Capital } \\
\hline Building \& Structures & 100 & 0 & 0 & 0 & 0 & 100 \\
\hline Tokamak Magnets* & 25 & 5.28 & 19.72 & 25 & 75 & 100 \\
\hline Tokamak Other & 25 & 0 & 25 & 25 & 75 & 100 \\
\hline Auxiliaries & 25 & 0 & 25 & 25 & 75 & 100 \\
\hline Assembly & 50 & 17 & 0 & 17 & 50 & 100 \\
\hline \multicolumn{7}{|l|}{ Construction Other } \\
\hline Design \& Management & 25 & 10 & 15 & 25 & 75 & 100 \\
\hline R\&D During Construction & 25 & 0 & 25 & 25 & 75 & 100 \\
\hline Preparation for Operation & 40 & 10 & 10 & 20 & 60 & 100 \\
\hline \multicolumn{7}{|l|}{ Operation (per year) ${ }^{\star \star}$} \\
\hline Tokamak Operation & 50 & 6.60 & 10.07 & 16.67 & 50 & 100 \\
\hline Experiments & 25 & 10.00 & 15.00 & 25.00 & 75 & 100 \\
\hline Decommissioning & 100 & 0 & 0 & 0 & 0 & 100 \\
\hline \multicolumn{7}{|c|}{$\begin{array}{l}\text { Each party is responsible for } 25 \% \text { of the total cost of the magnets. A portion of this cost is } \\
\text { designated as labor for magnet assembly at the host site. The fraction of non-host costs } \\
\text { incurred at the host site for labor is calculated in Table E.4. } \\
\text { ** Non-host costs for "Tokamak Operation" and "Experiments" incurred at the host site and } \\
\text { at home are calculated in Table E.7. }\end{array}$} \\
\hline
\end{tabular}


TABLE E.2 Summary of Host and Non-Host Life-Cycle Costs: Reference Case

\begin{tabular}{|c|c|c|c|c|c|c|c|c|}
\hline \multirow[b]{3}{*}{ Cost Category } & \multicolumn{8}{|c|}{ Life-Cycle Costs (billions of 1994 dollars) } \\
\hline & \multirow[b]{2}{*}{$\begin{array}{l}\text { Host } \\
\text { Cost }\end{array}$} & \multicolumn{3}{|c|}{ Non-Host Cost (Each Party) } & \multicolumn{3}{|c|}{ Total Non-Host Cost } & \multirow[b]{2}{*}{$\begin{array}{l}\text { Total } \\
\text { Cost }\end{array}$} \\
\hline & & $\begin{array}{l}\text { At Host } \\
\text { Site }^{*}\end{array}$ & $\begin{array}{c}\text { At } \\
\text { Home }\end{array}$ & Total & $\begin{array}{l}\text { At Host } \\
\text { Site }\end{array}$ & $\begin{array}{c}\text { At } \\
\text { Home }\end{array}$ & Total & \\
\hline \multicolumn{9}{|l|}{ Construction Capital } \\
\hline Building \& Structures & 0.860 & 0 & 0 & 0 & 0 & 0 & 0 & 0.860 \\
\hline Tokamak Magnets & 0.631 & 0.133 & 0.498 & 0.631 & 0.400 & 1.49 & 1.893 & 2.524 \\
\hline Tokamak Other & 0.450 & 0.000 & 0.450 & 0.450 & 0.000 & 1.35 & 1.351 & 1.802 \\
\hline Auxiliaries & 0.294 & 0.000 & 0.294 & 0.294 & 0.000 & 0.88 & 0.882 & 1.176 \\
\hline Assembly & 0.219 & 0.073 & 0.000 & 0.073 & 0.219 & 0.00 & 0.219 & 0.438 \\
\hline Total & 2.455 & 0.206 & 1.242 & 1.449 & 0.619 & 3.726 & 4.346 & 6.800 \\
\hline \multicolumn{9}{|l|}{ Construction Other } \\
\hline Design \& Management & 0.475 & 0.190 & 0.285 & 0.475 & 0.570 & 0.86 & 1.425 & 1.900 \\
\hline R\&D During Construction & 0.100 & 0.000 & 0.100 & 0.100 & 0.000 & 0.30 & 0.300 & 0.400 \\
\hline Preparation for Operation & 0.360 & 0.090 & 0.090 & 0.180 & 0.270 & 0.27 & 0.540 & 0.900 \\
\hline Total Construction & 3.390 & 0.486 & 1.717 & 2.204 & 1.459 & 5.151 & 6.611 & 10.00 \\
\hline \multicolumn{9}{|l|}{ Operation } \\
\hline Tokamak Operation & 2.880 & 0.380 & 0.580 & 0.960 & 1.140 & 1.740 & 2.880 & 5.760 \\
\hline Experiments & 0.720 & 0.288 & 0.432 & 0.720 & 0.864 & 1.296 & 2.160 & 2.880 \\
\hline Decommissioning & 1.00 & 0 & 0 & 0 & 0 & 0 & 0 & 1.00 \\
\hline Total & 7.990 & 1.155 & 2.729 & 3.884 & 3.464 & 8.187 & 11.651 & 19.64 \\
\hline$\%$ Total Cost & $40.68 \%$ & $5.88 \%$ & $13.89 \%$ & $19.77 \%$ & $17.64 \%$ & $41.68 \%$ & $59.32 \%$ & \\
\hline
\end{tabular}


TABLE E.3 Host/Non-Host Annual Costs: Reference Case

\begin{tabular}{|c|c|c|c|c|c|c|c|c|c|}
\hline \multirow[b]{3}{*}{ Year } & \multirow[b]{3}{*}{ Activity* } & \multicolumn{8}{|c|}{ Annual Costs (billions of 1994 dollars) } \\
\hline & & \multirow[b]{2}{*}{ Host Costs } & \multicolumn{3}{|c|}{ Non-Host Costs (Each Party) } & \multicolumn{3}{|c|}{ Total Non-Host Costs } & \multirow[b]{2}{*}{ Total Costs } \\
\hline & & & $\begin{array}{l}\text { At Host } \\
\text { Site }\end{array}$ & $\begin{array}{c}\text { At } \\
\text { Home }\end{array}$ & Total & $\begin{array}{l}\text { At Host } \\
\text { Site }^{\star \star}\end{array}$ & $\begin{array}{c}\text { At } \\
\text { Home }\end{array}$ & Total & \\
\hline 1999 & Construction & 0.195 & 0.034 & 0.110 & 0.144 & 0.102 & 0.331 & 0.433 & 0.628 \\
\hline 2000 & Construction & 0.440 & 0.055 & 0.234 & 0.289 & 0.164 & 0.703 & 0.867 & 1.308 \\
\hline 2001 & Construction & 0.563 & 0.065 & 0.297 & 0.362 & 0.195 & 0.890 & 1.085 & 1.648 \\
\hline 2002 & Construction & 0.563 & 0.065 & 0.297 & 0.362 & 0.195 & 0.890 & 1.085 & 1.648 \\
\hline 2003 & Construction & 0.440 & 0.055 & 0.234 & 0.289 & 0.164 & 0.703 & 0.867 & 1.308 \\
\hline 2004 & Construction & 0.425 & 0.071 & 0.199 & 0.271 & 0.214 & 0.598 & 0.812 & 1.238 \\
\hline 2005 & Construction & 0.443 & 0.076 & 0.204 & 0.280 & 0.228 & 0.612 & 0.839 & 1.283 \\
\hline \multirow[t]{2}{*}{2006} & Construction & 0.321 & 0.066 & 0.142 & 0.207 & 0.197 & 0.425 & 0.622 & 0.943 \\
\hline & $\begin{array}{l}\text { Total Construction } \\
\text { Expenditures } \\
(1999-2006)\end{array}$ & 3.390 & 0.486 & 1.717 & 2.204 & 1.459 & 5.151 & 6.611 & 10.000 \\
\hline \multirow[t]{2}{*}{$\begin{array}{c}2007 \\
\text { through } \\
2024 \\
\end{array}$} & Operation & 0.200 & 0.037 & 0.056 & 0.093 & 0.111 & 0.169 & 0.280 & 0.480 \\
\hline & $\begin{array}{l}\text { Total Operating } \\
\text { Expenditures } \\
\text { (2007-2024) }\end{array}$ & 3.600 & 0.668 & 1.012 & 1.680 & 2.004 & 3.036 & 5.040 & 8.640 \\
\hline \multirow[t]{2}{*}{$\begin{array}{c}2025 \\
\text { through } \\
2028 \\
\end{array}$} & Decommissioning & 0.250 & 0 & 0 & 0 & 0 & 0 & 0 & 0.250 \\
\hline & $\begin{array}{c}\text { Total } \\
\text { Decommissioning } \\
\text { Expenditures } \\
(2025-2028)\end{array}$ & 1.000 & 0 & 0 & 0 & 0 & 0 & 0 . & 1.000 \\
\hline \multicolumn{10}{|c|}{$\begin{array}{lll}19.64 & \text { Total } & 19.6\end{array}$} \\
\hline
\end{tabular}


TABLE E.4 Labor Costs for Host Site Magnet Assembly: Reference Case

\begin{tabular}{|c|c|c|c|c|c|c|c|c|c|}
\hline \multirow[b]{2}{*}{ Item ${ }^{\star}$} & \multicolumn{4}{|c|}{ Tokamak Magnet Costs } & \multicolumn{5}{|c|}{ Labor Breakdown } \\
\hline & $\begin{array}{l}\text { TAC-4 } \\
\$ B(93) \\
\end{array}$ & $\begin{array}{c}\text { TAC-4 with } \\
\text { Contingency } \\
\$ B(93) \\
\end{array}$ & $\begin{array}{c}\text { TAC-4 } \\
\text { Escalated } \\
\$ B(94) \\
\end{array}$ & $\begin{array}{c}\text { Reference } \\
\text { Case } \\
\$ B(94) \\
\end{array}$ & $\begin{array}{l}\% \text { Magnet } \\
\text { Cost for } \\
\text { Labor at } \\
\text { Host Site } \\
\end{array}$ & $\begin{array}{c}\text { Total Labor } \\
\text { Cost at Host } \\
\text { Site } \\
\$ B(94) \\
\end{array}$ & $\begin{array}{c}\% \text { Labor } \\
\text { Cost Paid } \\
\text { by Each } \\
\text { Party } \\
\end{array}$ & $\begin{array}{c}\text { Labor Cost } \\
\text { at Host Site } \\
\text { (Each Party) } \\
\$ \mathrm{~B}(94) \\
\end{array}$ & $\begin{array}{l}\text { Total Labor } \\
\text { Cost at Host } \\
\text { Site by All } \\
\text { Non-Host } \\
\text { Parties \$B(94) }\end{array}$ \\
\hline TF Magnets & 1.090 & 1.308 & 1.360 & 1.291 & 25 & 0.323 & 25 & 0.081 & 0.242 \\
\hline CS Magnets & 0.227 & 0.272 & 0.283 & 0.269 & 25 & 0.067 & 25 & 0.017 & 0.050 \\
\hline PF Magnets & 0.484 & 0.581 & 0.604 & 0.573 & 25 & 0.143 & 25 & 0.036 & 0.107 \\
\hline All Other & 0.330 & 0.396 & 0.412 & 0.391 & 0 & 0.000 & 0 & 0.000 & 0.000 \\
\hline Total & 2.131 & 2.557 & 2.660 & 2.524 & & 0.533 & & 0.133 & 0.400 \\
\hline & & & & & & & $\begin{array}{c}\% \text { of Total } \\
\text { Magnet } \\
\text { Cost }\end{array}$ & 5.28 & 15.85 \\
\hline
\end{tabular}


TABLE E.5 Non-Host Spending Assumptions for Labor at Host Site: Reference Case

\begin{tabular}{|c|c|c|c|c|c|c|c|c|c|c|}
\hline \multirow[b]{2}{*}{ Cost Category } & \multirow[b]{2}{*}{$\begin{array}{l}\text { Cost } \\
\$ B(94)\end{array}$} & \multicolumn{4}{|c|}{$\%$ Cost by Category* } & \multicolumn{3}{|c|}{$\begin{array}{l}\% \text { Non-Host Cost } \\
\text { (Each Party) }^{\star \star}\end{array}$} & \multicolumn{2}{|c|}{$\begin{array}{c}\text { Non-Host Labor } \\
\text { At Host Site } \$ B(94)^{k \star \star}\end{array}$} \\
\hline & & 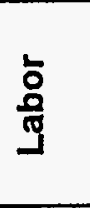 & 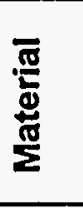 & 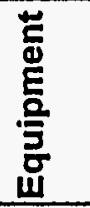 & Total & $\begin{array}{l}\text { At Host } \\
\text { Site }\end{array}$ & $\begin{array}{c}\text { At } \\
\text { Home }\end{array}$ & Total & Each Party & $\begin{array}{c}\text { Total All } \\
\text { Non-Host } \\
\text { Parties }\end{array}$ \\
\hline \multicolumn{11}{|l|}{ Construction Capital } \\
\hline Building \& Structures & 0.86 & 65 & 35 & 0 & 100 & 0 & 0 & 0 & 0.000 & 0.000 \\
\hline Tokamak Magnets & 2.52 & 21 & 0 & 79 & 100 & 5.28 & 19.72 & 25 & 0.133 & 0.400 \\
\hline Tokamak Other & 1.80 & 0 & 0 & 100 & 100 & 0 & 25 & 25 & 0.000 & 0.000 \\
\hline Auxiliaries & 1.18 & 45 & 0 & 55 & 100 & 0 & 25 & 25 & 0.000 & 0.000 \\
\hline Assembly & 0.44 & 100 & 0 & 0 & 100 & 17 & 0 & 17 & 0.073 & 0.219 \\
\hline \multicolumn{11}{|l|}{ Construction Other } \\
\hline Design \& Management & 1.90 & 100 & 0 & 0 & 100 & 10 & 15 & 25 & 0.190 & 0.570 \\
\hline R\&D During Construction & 0.40 & 60 & 20 & 20 & 100 & 0 & 25 & 25 & 0.000 & 0.000 \\
\hline Preparation for Operation & 0.90 & 50 & 30 & 20 & 100 & 10 & 10 & 20 & 0.090 & 0.270 \\
\hline Total Construction & 10.00 & & & & & & & & 0.486 & 1.459 \\
\hline & & & & & & & & & & \\
\hline \multicolumn{11}{|l|}{ Operation (per year) } \\
\hline Tokamak Operation & 0.32 & 33 & 22 & 45 & 100 & 6.60 & 10.07 & 16.67 & 0.380 & 1.140 \\
\hline Experiments & 0.16 & 40 & 10 & 50 & 100 & 10.00 & 15.00 & 25 & 0.216 & 0.648 \\
\hline Decommissioning & 1.00 & 60 & 20 & 20 & 100 & 0 & 0 & 0 & 0 & 0 \\
\hline & & & & & & & & $\begin{array}{l}\text { Life- } \\
\text { Cycle } \\
\text { Total }\end{array}$ & 1.083 & 3.248 \\
\hline \multicolumn{11}{|c|}{$\begin{array}{l}\text { Although the Tokamak Magnets are shown as } 100 \% \text { equipment, a portion of the total cost is for labor associated } \\
\text { with on-site magnet assembly. Table E.4 provides the labor breakdown for magnets. } \\
\text { Values shown for Tokamak Magnets are calculated in Table E.4. Values shown for Tokamak Operation and Experiments } \\
\text { are calculated in Table E.7. } \\
\text { Values shown for operation are for an 18-year operating life. }\end{array}$} \\
\hline
\end{tabular}


TABLE E. 6 Host Spending Assumptions for Labor at Host Site: Reference Case

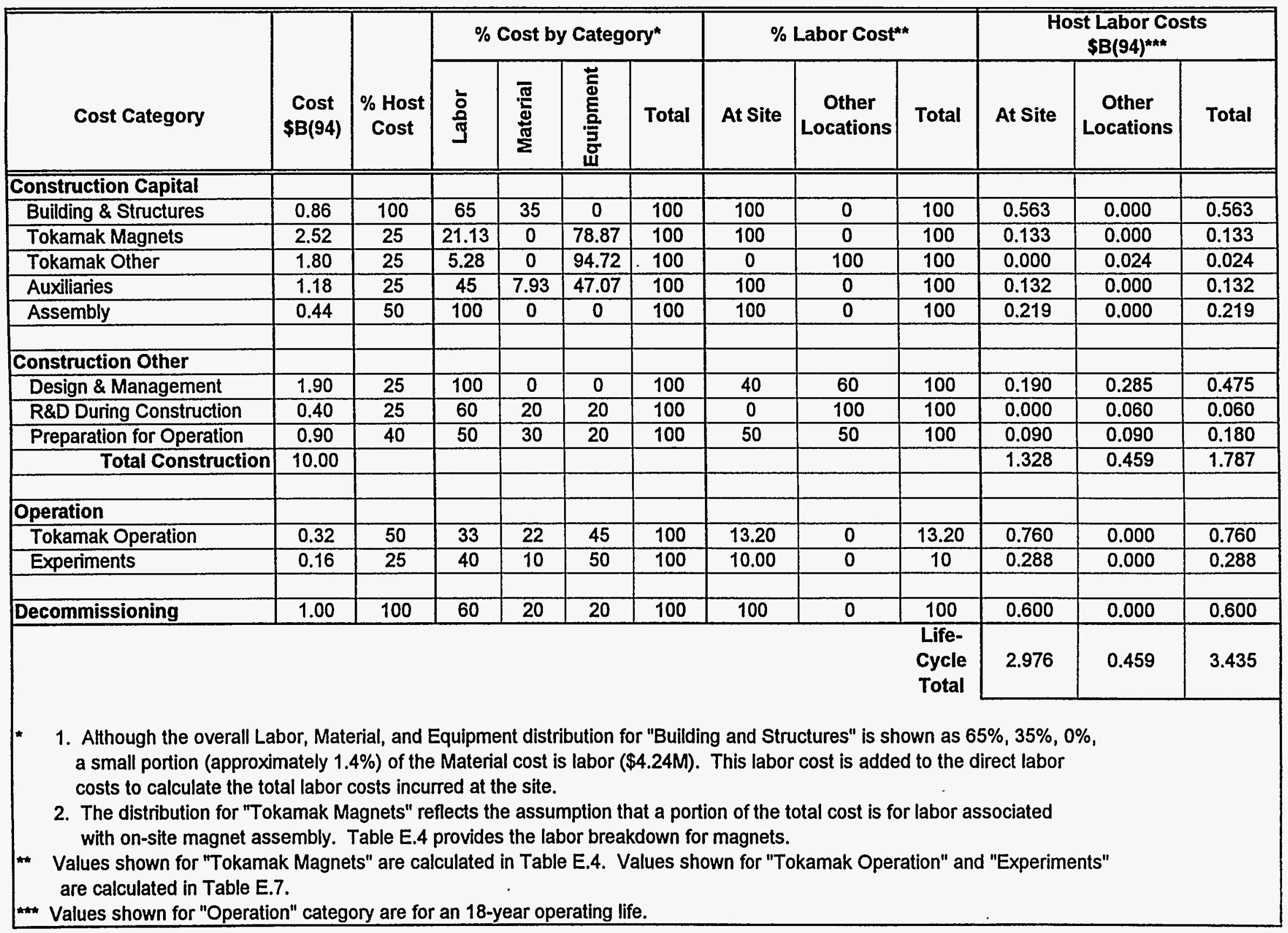


TABLE E.7 Non-Host Labor, Material, and Equipment Cost Breakdown (Each Party, Annual) for Operation Categories: Reference Case

\begin{tabular}{|c|c|c|c|c|c|c|c|c|c|c|c|c|c|c|c|c|c|c|}
\hline \multirow[b]{2}{*}{ Category ${ }^{\star \star}$} & \multirow[b]{2}{*}{$\begin{array}{c}\text { Total } \\
\text { Annual } \\
\text { Cost } \\
\sin (94) \\
\end{array}$} & \multicolumn{3}{|c|}{$\begin{array}{c}\% \text { Total Cost by } \\
\text { Category }\end{array}$} & \multicolumn{3}{|c|}{$\begin{array}{c}\text { Total Cost by } \\
\text { Category } \$ M(94)\end{array}$} & \multirow[b]{2}{*}{$\begin{array}{c}\text { Non-Host } \\
\text { Cost (\% of } \\
\text { Total } \\
\text { Cost) }\end{array}$} & \multirow[b]{2}{*}{$\begin{array}{l}\text { Non- } \\
\text { Host } \\
\text { Cost } \\
\text { SM(94) } \\
\end{array}$} & \multicolumn{3}{|c|}{$\begin{array}{l}\% \text { Non-Host Cost } \\
\text { by Category* }\end{array}$} & \multicolumn{3}{|c|}{$\begin{array}{c}\text { Non-Host Cost at } \\
\text { Host Site } \\
\text { by Category \$M(94) }\end{array}$} & \multicolumn{3}{|c|}{$\begin{array}{c}\text { Non-Host Cost at } \\
\text { Home } \\
\text { by Category \$M(94) }\end{array}$} \\
\hline & & 홈 & 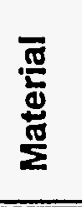 & 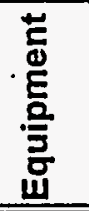 & ᄂ & 要 & 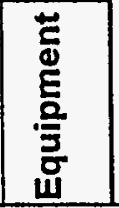 & & & 竞 & 宽 & 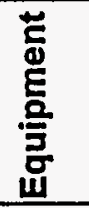 & 亯 & 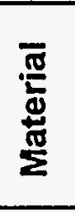 & 䓂 & 京 & 焉 & 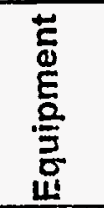 \\
\hline $\begin{array}{l}\text { Tokamak } \\
\text { Operation }\end{array}$ & 320 & 33 & 22 & 45 & 105.6 & 70.4 & 144.0 & 16.67 & 53.33 & 20 & 0 & 22 & 21.12 & 0 & 0 & 0 & 0 & 32.21 \\
\hline Experiments & 160 & 40 & 10 & 50 & 64.0 & 16.0 & 80.0 & 25.00 & 40.00 & 25 & 25 & 25 & 12 & 4 & 0 & 4 & 0 & 20 \\
\hline Total & 480 & & & & 169.6 & 86.4 & 224.0 & & 93.33 & & & & 33.12 & 4 & 0 & 4.00 & 0 & 52.21 \\
\hline $\begin{array}{l}\text { * Applies to t } \\
\text { Tokamak O } \\
\text { Experiment }\end{array}$ & $\begin{array}{l}\text { ts: labo } \\
\text { at the }\end{array}$ & & & & & -host & host & $\begin{array}{l}5 \% \text { ) and hon } \\
\text { ite; all mater } \\
\end{array}$ & ial costs & 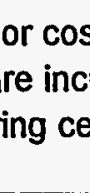 & & o); & $\begin{array}{l}\text { mater } \\
\text { tt; equ } \\
\text { iterial }\end{array}$ & me & pur & sed & & \\
\hline
\end{tabular}


TABLE E.8 Host Labor, Material, and Equipment Cost Breakdown (Annual) for Operation Categories: Reference Case

\begin{tabular}{|c|c|c|c|c|c|c|c|c|c|c|c|c|c|c|c|}
\hline \multirow[b]{2}{*}{ Category } & \multirow[b]{2}{*}{$\begin{array}{c}\text { Total } \\
\text { Annual } \\
\text { Cost } \\
\text { SM(94) } \\
\end{array}$} & \multicolumn{3}{|c|}{\begin{tabular}{|c|}
$\%$ Total Cost by \\
Category
\end{tabular}} & \multicolumn{3}{|c|}{$\begin{array}{c}\text { Total Cost by } \\
\text { Category } \$ M(94)\end{array}$} & \multirow[b]{2}{*}{$\begin{array}{c}\text { Host } \\
\text { Cost (\% } \\
\text { of Total } \\
\text { Cost) }\end{array}$} & \multirow[b]{2}{*}{$\begin{array}{l}\text { Total } \\
\text { Host } \\
\text { Cost } \\
\text { SM(94) }\end{array}$} & \multicolumn{3}{|c|}{$\begin{array}{c}\text { \% Host Cost by } \\
\text { Category* }\end{array}$} & \multicolumn{3}{|c|}{$\begin{array}{c}\text { Total Host Cost } \\
\text { by Category } \$ M(94)\end{array}$} \\
\hline & & 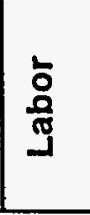 & 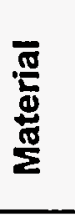 & 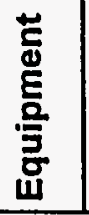 & 总 & 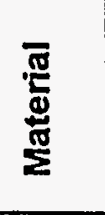 & 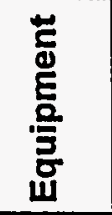 & & & ঃั & 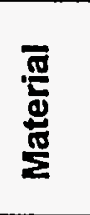 & 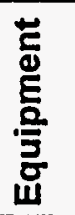 & 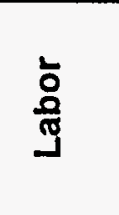 & 宽 & 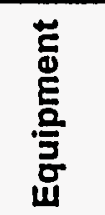 \\
\hline $\begin{array}{l}\text { Tokamak } \\
\text { Operation }\end{array}$ & 320 & 33 & 22 & 45 & 105.6 & 70.4 & 144.0 & 50 & 160 & 40 & 100 & 33 & 42.24 & 70.4 & 47.36 \\
\hline Experiments & 160 & 40 & 10 & 50 & 64.0 & 16.0 & 80.0 & 25 & 40 & 25 & 25 & 25 & 16 & 4 & 20 \\
\hline Total & 480 & & & & 169.6 & 86.4 & 224.0 & & 200 & & & & 58.24 & 74.4 & 6736 \\
\hline
\end{tabular}


TABLE E.9 Annual Labor Costs at Host Site: Reference Case

\begin{tabular}{|c|c|c|c|c|c|}
\hline \multirow[b]{2}{*}{ Year } & \multirow[b]{2}{*}{ Activity* } & \multicolumn{4}{|c|}{ Annual Labor Costs (billions of 1994 dollars) } \\
\hline & & Host Costs & $\begin{array}{c}\text { Non-Host } \\
\text { Costs } \\
\text { (Each Party) }\end{array}$ & $\begin{array}{l}\text { Total } \\
\text { Non-Host } \\
\text { Costs }\end{array}$ & Total \\
\hline 1999 & Construction & 0.076 & 0.034 & 0.102 & 0.178 \\
\hline 2000 & Construction & 0.181 & 0.055 & 0.164 & 0.345 \\
\hline 2001 & Construction & 0.233 & 0.065 & 0.195 & 0.428 \\
\hline 2002 & Construction & 0.233 & 0.065 & 0.195 & 0.428 \\
\hline 2003 & Construction & 0.181 & 0.055 & 0.164 & 0.345 \\
\hline 2004 & Construction & 0.156 & 0.071 & 0.214 & 0.370 \\
\hline 2005 & Construction & 0.160 & 0.076 & 0.228 & 0.388 \\
\hline \multirow[t]{2}{*}{2006} & Construction & 0.108 & 0.066 & 0.197 & 0.304 \\
\hline & $\begin{array}{l}\text { Total Labor Costs for } \\
\text { Construction } \\
(1999-2006)\end{array}$ & 1.328 & 0.486 & 1.459 & 2.787 \\
\hline \multirow{2}{*}{$\begin{array}{c}2007 \\
\text { through } \\
2024 \\
\end{array}$} & Operation & 0.0582 & 0.0331 & 0.0994 & 0.1576 \\
\hline & $\begin{array}{l}\text { Total Labor Costs for } \\
\text { Operation } \\
(2007-2024)\end{array}$ & 1.048 & 0.596 & 1.788 & 2.837 \\
\hline \multirow{2}{*}{$\begin{array}{c}2025 \\
\text { through } \\
2028 \\
\end{array}$} & Decommissioning & 0.150 & 0 & 0 & 0.150 \\
\hline & $\begin{array}{l}\text { Total Labor Costs for } \\
\text { Decommissioning } \\
(2025-2028)\end{array}$ & 0.600 & 0 & 0 & 0.600 \\
\hline \multicolumn{2}{|r|}{ Life-Cycle Total } & 2.976 & 1.083 & 3.248 & 6.224 \\
\hline
\end{tabular}


TABLE E.10 Host Cost Breakdown by Cost Category: Reference Case

\begin{tabular}{|c|c|c|c|c|c|c|c|c|c|c|}
\hline \multirow[b]{2}{*}{ Cost Category } & \multirow[b]{2}{*}{$\begin{array}{l}\text { Cost } \\
\$ B(94)\end{array}$} & \multirow[b]{2}{*}{$\begin{array}{c}\% \text { Host } \\
\text { Cost }\end{array}$} & \multicolumn{4}{|c|}{$\%$ Cost by Category } & \multicolumn{3}{|c|}{$\begin{array}{c}\text { Cost by Category*n } \\
\text { \$B(94) }\end{array}$} & \multirow[b]{2}{*}{$\begin{array}{c}\text { Total Host } \\
\text { Cost } \\
\$ B(94)\end{array}$} \\
\hline & & & 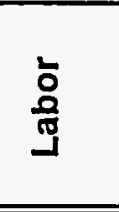 & 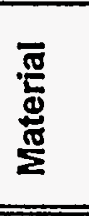 & 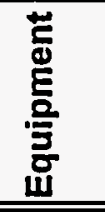 & Total & 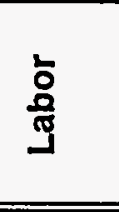 & 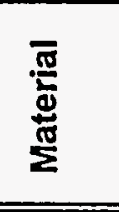 & 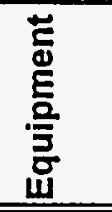 & \\
\hline \multicolumn{11}{|l|}{ Construction Capital } \\
\hline Building \& Structures & 0.860 & 100 & 65 & 35 & 0 & 100 & 0.563 & 0.297 & 0.000 & 0.860 \\
\hline Tokamak Magnets & 2.524 & 25 & 21.13 & 0 & 78.87 & 100 & 0.133 & 0.000 & 0.498 & 0.631 \\
\hline Tokamak Other & 1.802 & 25 & 5.28 & 0 & 94.72 & 100 & 0.024 & 0.000 & 0.427 & 0.450 \\
\hline Auxiliaries & 1.176 & 25 & 45 & 7.93 & 47.07 & 100 & 0.132 & 0.023 & 0.138 & 0.294 \\
\hline Assembly & 0.438 & 50 & 100 & 0 & 0 & 100 & 0.219 & 0.000 & 0.000 & 0.219 \\
\hline Total & 6.800 & & & & & & 1.072 & 0.320 & 1.063 & 2.455 \\
\hline \multicolumn{11}{|l|}{ Construction Other } \\
\hline Design \& Management & 1.900 & 25 & 100 & 0 & 0 & 100 & 0.475 & 0.000 & 0.000 & 0.475 \\
\hline R\&D During Construction & 0.400 & 25 & 60 & 20 & 20 & 100 & 0.060 & 0.020 & 0.020 & 0.100 \\
\hline Preparation for Operation & 0.900 & 40 & 50 & 30 & 20 & 100 & 0.180 & 0.108 & 0.072 & 0.360 \\
\hline $\begin{array}{r}\text { Total Construction } \\
\end{array}$ & 10.000 & & & & & & 1.787 & 0.448 & 1.155 & 3.390 \\
\hline \multirow{2}{*}{\multicolumn{11}{|c|}{ Operation }} \\
\hline Tokamak Operation & 0.320 & 50 & 33 & 22 & 45 & 100 & 0760 & 1267 & 0852 & \\
\hline Experiments & 0.160 & 25 & 40 & 10 & 50 & 100 & 0288 & 0073 & $\frac{0.052}{0.360}$ & 2.880 \\
\hline Total Operation & & & & & & & 1.048 & 1.339 & 1.212 & $\frac{0.720}{3.600}$ \\
\hline & & & & & & & & & & \\
\hline Decommissioning & 1.000 & 100 & 60 & 20 & 20 & 100 & 0.600 & 0.200 & 0.200 & 1.000 \\
\hline \begin{tabular}{|c|} 
Life-Cycle Total \\
\end{tabular} & & & & & & & 3.435 & 1.987 & 2.567 & 7.990 \\
\hline
\end{tabular}

- 1. Although the overall Labor, Material, and Equipment distribution for "Building and Structures" is shown as $65 \%, 35 \%, 0 \%$, a small portion (approximately $1.4 \%$ ) of the Material cost is labor $(\$ 4.24 \mathrm{M})$. This labor cost is added to the direct labor costs to calculate the total labor costs incurred at the site.

2. The distribution for "Tokamak Magnets" reflects the assumption that a portion of the total cost is for labor associated with on-site magnet assembly. Table E.4 provides the labor breakdown for magnets.

** Values shown for "Tokamak Magnets" are calculated in Table E.4. Values shown for "Tokamak Operation" and "Experiments" are calculated in Table E.7.

* Values shown for "Operation" category are for an 18-year operating life. 
TABLE E.11 U.S. Host Versus U.S. Non-Host Cost Comparison: Reference Case

\begin{tabular}{|c|c|c|c|c|c|c|c|}
\hline \multirow[b]{2}{*}{ Cost Category } & \multicolumn{4}{|c|}{ U.S. Host (billions of 1994 dollars) } & \multicolumn{3}{|c|}{ U.S. Non-Host (billions of 1994 dollars) } \\
\hline & $\begin{array}{l}\text { Total U.S. } \\
\text { Costs }\end{array}$ & $\begin{array}{c}\text { Total } \\
\text { Non-Host } \\
\text { Costs at Host } \\
\text { Site } \\
\end{array}$ & $\begin{array}{c}\text { Actual } \\
\text { Non-Host } \\
\text { Expenditures } \\
\text { in U.S." } \\
\end{array}$ & $\begin{array}{l}\text { U.S. Costs + } \\
\text { Non-Host } \\
\text { Expenditures } \\
\text { in U.S. }\end{array}$ & $\begin{array}{l}\text { U.S. } \\
\text { Expenditures } \\
\text { in U.S. }\end{array}$ & \begin{tabular}{|c|} 
U.S. \\
Expenditures \\
at Foreign Site
\end{tabular} & $\begin{array}{c}\text { Total U.S. } \\
\text { Costs }\end{array}$ \\
\hline \multicolumn{8}{|l|}{ Construction Capital } \\
\hline Building \& Structures & 0.860 & 0.000 & 0.000 & 0.860 & 0.000 & 0.000 & 0.000 \\
\hline Tokamak Magnets & 0.631 & 0.400 & 0.230 & 0.861 & 0.554 & 0.077 & 0.631 \\
\hline Tokamak Other & 0.450 & 0.000 & 0.000 & 0.450 & 0.450 & 0.000 & 0.450 \\
\hline Auxiliaries & 0.294 & 0.000 & 0.000 & 0.294 & 0.294 & 0.000 & 0.294 \\
\hline Assembly & 0.219 & 0.219 & 0.126 & 0.345 & 0.031 & 0.042 & 0.073 \\
\hline Total & 2.455 & 0.619 & 0.356 & 2.811 & 1.330 & 0.119 & 1.449 \\
\hline \multicolumn{8}{|l|}{ Construction Other } \\
\hline Design \& Management & 0.475 & 0.570 & 0.328 & 0.803 & 0.366 & 0.109 & 0.475 \\
\hline R\&D During Construction & 0.100 & 0.000 & 0.000 & 0.100 & 0.100 & 0.000 & 0.100 \\
\hline Preparation for Operation & 0.360 & 0.270 & 0.155 & 0.515 & 0.128 & 0.052 & 0.180 \\
\hline Total Construction & 3.390 & 1.459 & 0.839 & 4.229 & 1.924 & 0.280 & 2.204 \\
\hline & & . & & & & & \\
\hline \multicolumn{8}{|l|}{ Operation } \\
\hline Tokamak Operation & 2.880 & 1.140 & 0.656 & 3.536 & 0.741 & 0.219 & 0.960 \\
\hline Experiments & 0.720 & 0.864 & 0.589 & 1.309 & 0.524 & 0.196 & 0.720 \\
\hline Total Operation & 3.600 & 2.004 & 1.244 & 4.844 & 1.265 & 0.415 & 1.680 \\
\hline & & & & & & & \\
\hline Decommissioning & 1.000 & 0.000 & 0.000 & 1.000 & 0.000 & 0.000 & 0.000 \\
\hline Life-Cycle Total & 7.990 & 3.464 & 2.083 & 10.073 & 3.189 & 0.694 & 3.884 \\
\hline \multicolumn{8}{|c|}{$\begin{array}{l}\text { * Non-host expenditures are calculated by adjusting the labor included in "Total Non-Host Costs at Host Site" as follows: } \\
\text { (a) } 5 / 6 \text { of the labor cost goes to pay for the scientists/engineers located at the host site; } 1 / 6 \text { is used to pay for support } \\
\text { at the home institution. } \\
\text { (b) Only } 69 \% \text { of the labor payments made to the scientists/engineers at the host site are actually spent at the site; the } \\
\text { remaining } 31 \% \text { is for taxes, pension contributions, etc. } \\
\text { * Aggregated total expenditures in U.S. economy due to ITER. }\end{array}$} \\
\hline
\end{tabular}


TABLE E.12 Labor Costs for Host Site Magnet Assembly: Magnet Option Case

\begin{tabular}{|c|c|c|c|c|c|c|c|c|c|}
\hline \multirow[b]{2}{*}{ Item } & \multicolumn{4}{|c|}{ Tokamak Magnet Costs } & \multicolumn{5}{|c|}{ Labor Breakdown } \\
\hline & $\begin{array}{l}\text { TAC-4 } \\
\$ B(93) \\
\end{array}$ & $\begin{array}{c}\text { TAC-4 with } \\
\text { Contingency } \\
\$ B(93)\end{array}$ & $\begin{array}{c}\text { TAC-4 } \\
\text { Escalated } \\
\$ B(94) \\
\end{array}$ & $\begin{array}{c}\text { Reference } \\
\text { Case } \\
\$ B(94) \\
\end{array}$ & $\begin{array}{l}\% \text { Magnet } \\
\text { Cost for } \\
\text { Labor at } \\
\text { Host Site }\end{array}$ & $\begin{array}{c}\text { Total Labor } \\
\text { Cost at Host } \\
\text { Site } \\
\$ B(94) \\
\end{array}$ & $\begin{array}{l}\% \text { Labor } \\
\text { Cost Paid } \\
\text { by Each } \\
\text { Party }\end{array}$ & $\begin{array}{c}\text { Labor Cost } \\
\text { at Host Site } \\
\text { (Each Party) } \\
\$ B(94)\end{array}$ & $\begin{array}{l}\text { Total Labor } \\
\text { Cost at Host } \\
\text { Site by All } \\
\text { Non-Host } \\
\text { Parties } \$ B(94)\end{array}$ \\
\hline TF Magnets & 1.090 & 1.308 & 1.360 & 1.291 & $6 \%$ & $1 \% 000 \%$ & 25 & $1 \% 0000 \%$ & .00000 \\
\hline CS Magnets & 0.227 & 0.272 & 0.283 & 0.269 & $9 \%$ & $1=0.0010$ & 25 & 0.0889 & .60 .800 \\
\hline PF Magnets & 0.484 & 0.581 & 0.604 & 0.573 & 25 & 0.143 & 25 & 0.036 & 0.107 \\
\hline \multirow[t]{2}{*}{ All Other } & 0.330 & 0.396 & 0.412 & 0.391 & 0 & 0.000 & 0 & 0.000 & 0.000 \\
\hline & & & & & & & & & \\
\hline Total & 2.131 & 2.557 & 2.660 & 2.524 & & 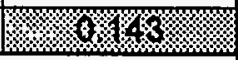 & & 0,606 & 60.107 \\
\hline & & & & & & & $\begin{array}{l}\% \text { of Total } \\
\text { Magnet } \\
\text { Cost }\end{array}$ & 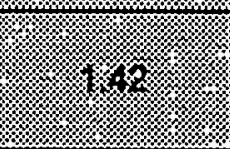 & . \\
\hline
\end{tabular}

Notes:

1. Shaded cells in spreadsheet indicate changes relative to Reference Case.

2. This case assumes that each Party makes the TF and CS magnets at home locations and ships them to an ITER site.

However, the PF magnets are assumed to be so large that there is no option to make them at home factories.

* $\mathrm{TF}=$ toroidal field; $\mathrm{CS}=$ central solenoid; $\mathrm{PF}=$ poloidal field. 
TABLE E.13 Host/Non-Host Funding and Spending Assumptions: Magnet Option Case

\begin{tabular}{|c|c|c|c|c|c|c|}
\hline \multirow[b]{2}{*}{ Cost Category } & \multirow[b]{2}{*}{$\begin{array}{c}\% \text { Host } \\
\text { Cost }\end{array}$} & \multicolumn{3}{|c|}{$\%$ Non-Host Cost (Each Party) } & \multirow[b]{2}{*}{$\begin{array}{c}\text { Total } \% \\
\text { Non-Host } \\
\text { Cost }\end{array}$} & \multirow[b]{2}{*}{ Total $\%$} \\
\hline & & $\begin{array}{l}\text { At Host } \\
\text { Site }\end{array}$ & $\begin{array}{c}\text { At } \\
\text { Home }\end{array}$ & Total & & \\
\hline \multicolumn{7}{|l|}{ Construction Capital } \\
\hline Building \& Structures & 100 & 0 & 0 & 0 & 0 & 100 \\
\hline Tokamak Magnets ${ }^{\star}$ & 25 & 1. & 28 siso & 25 & 75 & 100 \\
\hline Tokamak Other & 25 & 0 & 25 & 25 & 75 & 100 \\
\hline Auxiliaries & 25 & 0 & 25 & 25 & 75 & 100 \\
\hline Assembly & 50 & 17 & 0 & 17 & 50 & 100 \\
\hline \multicolumn{7}{|l|}{ Construction Other } \\
\hline Design \& Management & 25 & 10 & 15 & 25 & 75 & 100 \\
\hline R\&D During Construction & 25 & 0 & 25 & 25 & 75 & 100 \\
\hline Preparation for Operation & 40 & 10 & 10 & 20 & 60 & 100 \\
\hline & & \\
\hline $\begin{array}{c}\text { Operation (per year) } \\
\text { Tokamak Operation }\end{array}$ & 50 & 6.60 & 10.07 & 16.67 & 50 & 100 \\
\hline Experiments & 25 & 10.00 & 15.00 & 25.00 & 75 & 100 \\
\hline Decommissioning & 100 & 0 & 0 & 0 & 0 & 100 \\
\hline \multicolumn{7}{|c|}{$\begin{array}{l}\text { Note: Shaded cells in spreadsheet indicate changes relative to Reference Case. } \\
\text { Each party is responsible for } 25 \% \text { of the total cost of the magnets. A portion of this cost is } \\
\text { designated as labor for magnet assembly at the host site. The \% non-host cost incurred at } \\
\text { the host site for labor is calculated in Table E.12. } \\
\text { Non-host costs for "Tokamak Operation" and "Experiments" incurred at the host site and } \\
\text { at home are calculated in Table E.7. }\end{array}$} \\
\hline
\end{tabular}




\begin{tabular}{|c|c|c|c|c|c|c|c|c|}
\hline & \multicolumn{8}{|c|}{ 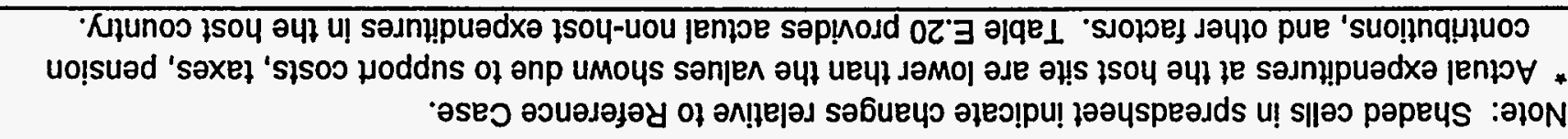 } \\
\hline \multirow{2}{*}{+961} & $\% Z \varepsilon^{\circ} 69$ & $0,1 \%$ & 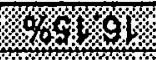 & $\% \angle L ' 6 L$ & $6600 \% 10$ & \% $84 \%$ & $\% 89^{\circ} 0 t$ & \multirow{2}{*}{$\begin{array}{l}150018\} 01 \% \\
12101\end{array}$} \\
\hline & $199^{\circ} 1 L$ & 6480 & (16\% & $788^{\circ} \varepsilon$ & 9882 & 2504 & $066^{\circ} \mathrm{L}$ & \\
\hline \multirow[t]{2}{*}{$00 \%$} & 0 & 0 & 0 & 0 & 0 & 0 & $00 \%$ & 6u!uo!̣s!̣umosad \\
\hline & & & & & & & & \\
\hline $088^{\circ} \mathrm{Z}$ & 0912 & $96 Z^{\prime} l$ & $\$ 98^{\circ} 0$ & $0 Z \angle \circ O$ & टह॰ 0 & $882^{\circ} 0$ & $0 Z \angle L^{\circ} 0$ & słuam!̣ədx \\
\hline \multirow[t]{2}{*}{$09 \angle S$} & $088^{\circ} \mathrm{Z}$ & $0+\angle \circ L$ & ott & $096^{\circ} 0$ & $089^{\circ} 0$ & $08 \varepsilon^{\prime} 0$ & $088^{\circ} \mathrm{Z}$ & 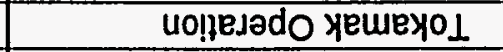 \\
\hline & & & & & & & & uo!jedədo \\
\hline & & & & & & & & \\
\hline $00.0 \mathrm{~L}$ & 119.9 & $8 x<9$ & (6) $1 \%$ & $+0 Z 2$ & 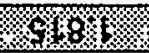 & $68.6 \%$ & $06 \varepsilon^{\circ} \varepsilon$ & 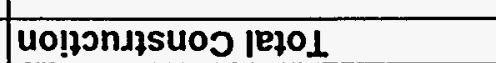 \\
\hline $006^{\circ} 0$ & $0 t 9^{\circ} 0$ & $\angle Z^{\prime} O$ & $0 \angle Z^{\circ} 0$ & $081^{\circ} 0$ & $060^{\circ} 0$ & $060^{\circ} 0$ & $09 \varepsilon^{\circ} 0$ & \multirow{4}{*}{ 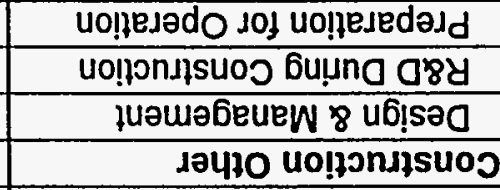 } \\
\hline $00 t^{\circ} 0$ & $00 \varepsilon^{\circ} 0$ & $0 \varepsilon^{\circ} 0$ & $000^{\circ} 0$ & $001^{\circ} 0$ & $001^{\circ} 0$ & $000^{\circ} 0$ & 0010 & \\
\hline \multirow[t]{2}{*}{$006^{\circ} 1$} & SZt' & $98^{\circ} 0$ & $0 \angle S^{\circ} 0$ & $S \angle t^{\circ} 0$ & $98 Z^{\circ} 0$ & $06 \mathrm{~L}^{\circ} 0$ & $S \angle t^{\circ} 0$ & \\
\hline & & & & & & & & \\
\hline & & & & & & & & \\
\hline $008^{\circ} 9$ & $9 \triangleright \varepsilon^{\circ} \downarrow$ & $66 \mathrm{x}$ & 2060 & $6+t^{\circ} 1$ & $3 x_{2}$ & 600.00 & SSt? & $\mid E+O 1$ \\
\hline $8 \varepsilon t^{\circ} 0$ & $612^{\circ} 0$ & $00^{\circ} 0$ & $612^{\circ} 0$ & $\varepsilon \angle 0^{\circ} O$ & $000^{\circ} 0$ & $\varepsilon \angle 0^{\circ} 0$ & $61 Z^{\prime} 0$ & Kiquess $\forall$ \\
\hline $9 L L L$ & $288^{\circ} 0$ & $88^{\circ} 0$ & $000 \%$ & $762^{\circ} 0$ & $76 Z^{\prime} 0$ & $000^{\circ} 0$ & $762^{\circ} 0$ & soụe!!!xn $\forall$ \\
\hline $208^{\circ} 1$ & LSE'L & $S \varepsilon^{\prime} L$ & $000^{\circ} 0$ & 0sto & $097^{\circ} 0$ & $000^{\circ} 0$ & OSt'0 & 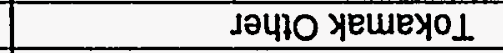 \\
\hline$\$ 29^{\circ} 2$ & $868^{\circ} \mathrm{L}$ & 1921. & 220100 & $189^{\circ} 0$ & 9690 & $9.00 \%$ & $189^{\circ} 0$ & slau6ew yeureyo 1 \\
\hline \multirow[t]{2}{*}{$098^{\circ} 0$} & 0 & 0 & 0 & 0 & 0 & 0 & $098^{\circ} 0$ & \multirow{2}{*}{ 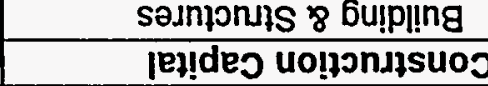 } \\
\hline & & & & & & & & \\
\hline \multirow[t]{2}{*}{$\begin{array}{l}1500 \\
18101\end{array}$} & |ejol & $\begin{array}{c}\text { का०० } \\
\mathcal{I H}\end{array}$ & $\begin{array}{c}\text { *27!S } \\
\text { 7SOH IV }\end{array}$ & $|E| O \perp$ & $\begin{array}{c}\text { कWOH } \\
\text { IH }\end{array}$ & $\begin{array}{c}\text { *ə)!S } \\
\text { ISOH IH }\end{array}$ & \multirow[t]{2}{*}{$\begin{array}{l}7505 \\
750 H\end{array}$} & \multirow[t]{3}{*}{ Кূобәјеว 150ว } \\
\hline & \multicolumn{3}{|c|}{ ISOJ 75OH-UON IEłOI } & \multicolumn{3}{|c|}{ 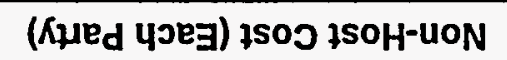 } & & \\
\hline & & (sJe)|op t & $6 !$ to suo! & !q) s750: & 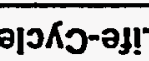 & & & \\
\hline
\end{tabular}


TABLE E.15 Host/Non-Host Annual Costs: Magnet Option Case

\begin{tabular}{|c|c|c|c|c|c|c|c|c|c|}
\hline \multirow[b]{3}{*}{ Year } & \multirow[b]{3}{*}{ Activity* } & \multicolumn{8}{|c|}{ Annual Costs (billions of 1994 dollars) } \\
\hline & & \multirow[b]{2}{*}{ Host Costs } & \multicolumn{3}{|c|}{ Non-Host Costs (Each Party) } & \multicolumn{3}{|c|}{ Total Non-Host Costs } & \multirow[b]{2}{*}{ Total Costs } \\
\hline & & & $\begin{array}{l}\text { At Host } \\
\text { Site }^{\star \star}\end{array}$ & $\begin{array}{c}\text { At } \\
\text { Home }\end{array}$ & Total & $\begin{array}{l}\text { At Host } \\
\text { Site }\end{array}$ & $\begin{array}{c}\text { At } \\
\text { Home }\end{array}$ & Total & \\
\hline 1999 & Construction & 0.195 & 0029 & 0.166 & 0.144 & $0.0 \% 8 \%$ & $6.646 \%$ & 0.433 & 0.628 \\
\hline 2000 & Construction & 0.440 & 0.640 & (0.2. & 0.289 & 6 & 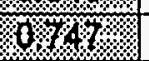 & 0.867 & 1.308 \\
\hline 2001 & Construction & 0.563 & 10646.1 & $0: 36=$ & 0.362 & $0.67 \%$ & 0.948. & 1.085 & 1.648 \\
\hline 2002 & Construction & 0.563 & \%,046\% & $10336 \%$ & 0.362 & 0013 & O.9948. & 1.085 & 1.648 \\
\hline 2003 & Construction & 0.440 & $\% 0040 \%$ & 10.249 & 0.289 & .0 .180 & 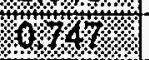 & 0.867 & 1.308 \\
\hline 2004 & Construction & 0.425 & ơo & \%o\%o\% & 0.271 & (1) & 10627 & 0.812 & 1.238 \\
\hline 2005 & Construction & 0.443 & WOEOS & 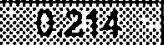 & 0.280 & 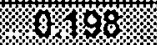 & 6644? & 0.839 & 1.283 \\
\hline \multirow[t]{2}{*}{2006} & Construction & 0.321 & (6.5\% & \% o & 0.207 & $0.6 \%$ & $0 \% 46 \%$ & 0.622 & 0.943 \\
\hline & $\begin{array}{c}\text { Total Construction } \\
\text { Expenditures } \\
(1999-2006)\end{array}$ & 3.390 & \%.9.8. & 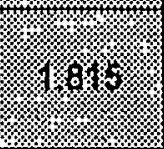 & 2.204 & 1.16169 & 28: & 6.611 & 10.000 \\
\hline \multirow{2}{*}{$\begin{array}{c}2007 \\
\text { through } \\
2024 \\
\end{array}$} & Operation & 0.200 & 0.037 & 0.056 & 0.093 & 0.111 & 0.169 & 0.280 & 0.480 \\
\hline & $\begin{array}{c}\text { Total Operating } \\
\text { Expenditures } \\
(2007-2024) \\
\end{array}$ & 3.600 & 0.668 & 1.012 & 1.680 & 2.004 & 3.036 & 5.040 & 8.640 \\
\hline \multirow{2}{*}{$\begin{array}{c}.2025 \\
\text { through } \\
2028 \\
\end{array}$} & Decommissioning & 0.250 & 0 & 0 & 0 & 0 & 0 & 0 & 0.250 \\
\hline & $\begin{array}{c}\text { Total } \\
\text { Decommissioning } \\
\text { Expenditures } \\
(2025-2028)\end{array}$ & 1.000 & 0 & 0 & 0 & 0 & 0 & 0 & 1.000 \\
\hline \multicolumn{10}{|c|}{$\begin{array}{lll}2 & \text { Total }\end{array}$} \\
\hline
\end{tabular}


TABLE E.16 Non-Host Spending Assumptions for Labor at Host Site: Magnet Option Case

\begin{tabular}{|c|c|c|c|c|c|c|c|c|c|c|}
\hline \multirow[b]{2}{*}{ Cost Category } & \multirow[b]{2}{*}{$\begin{array}{c}\text { Cost } \\
\$ B(94)\end{array}$} & \multicolumn{4}{|c|}{$\%$ Cost by Category* } & \multicolumn{3}{|c|}{$\begin{array}{l}\text { \% Non-Host Cost } \\
\text { (Each Party) }^{\text {(En }}\end{array}$} & \multicolumn{2}{|c|}{$\begin{array}{c}\text { Non-Host Labor } \\
\text { At Host Site \$B(94) }\end{array}$} \\
\hline & & 总 & 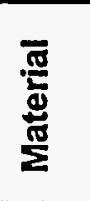 & 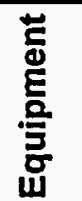 & Total & $\begin{array}{l}\text { At Host } \\
\text { Site }\end{array}$ & $\begin{array}{c}\text { At } \\
\text { Home }\end{array}$ & Total & Each Party & $\begin{array}{c}\text { Total All } \\
\text { Non-Host } \\
\text { Parties }\end{array}$ \\
\hline \multicolumn{11}{|l|}{ Construction Capital } \\
\hline Building \& Structures & 0.86 & 65 & 35 & 0 & 100 & 0 & 0 & 0 & 0.000 & 0.000 \\
\hline Tokamak Magnets & 2.52 & 6 & 0 & 94 & 100 & \% & $23 \% 8$ & 25 & \%006 & $0.0 \%$ \\
\hline Tokamak Other & 1.80 & 0 & 0 & 100 & 100 & 0 & 25 & 25 & 0.000 & 0.000 \\
\hline Auxiliaries & 1.18 & 45 & 0 & 55 & 100 & 0 & 25 & 25 & 0.000 & 0.000 \\
\hline Assembly & 0.44 & 100 & 0 & 0 & 100 & 17 & 0 & 17 & 0.073 & 0.219 \\
\hline \multicolumn{11}{|l|}{ Construction Other } \\
\hline \begin{tabular}{|l} 
Desian \& Management \\
\end{tabular} & 1.90 & 100 & 0 & 0 & 100 & 10 & 15 & 25 & 0.190 & 0570 \\
\hline R\&D During Construction & 0.40 & 60 & 20 & 20 & 100 & 0 & 25 & 25 & 0.000 & 0.000 \\
\hline Preparation for Operation & 0.90 & 50 & 30 & 20 & 100 & 10 & 10 & 20 & 0.090 & 0.270 \\
\hline Total Construction & 10.00 & & & & & & & & 0.389 & 1.167 \\
\hline \multirow{2}{*}{\multicolumn{11}{|c|}{ Operation (per year) }} \\
\hline & & & & & & & & & & \\
\hline Tokamak Operation & 0.32 & 33 & 22 & 45 & 100 & 6.60 & 10.07 & 16.67 & 0.380 & 1.140 \\
\hline Experiments & 0.16 & 40 & 10 & 50 & 100 & 10.00 & 15.00 & 25 & 0.216 & 0.648 \\
\hline Decommissioning & 1.00 & 60 & 20 & 20 & 100 & 0 & 0 & 0 & 0 & 0 \\
\hline & & & & & & & & $\begin{array}{l}\text { Life- } \\
\text { Cycle } \\
\text { Total }\end{array}$ & $2=8.985$ & .1. \\
\hline \multicolumn{11}{|c|}{$\begin{array}{l}\text { Note: Shaded cells in spreadsheet indicate changes relative to Reference Case. } \\
\text { Although the Tokamak Magnets are shown as } 100 \% \text { equipment, a portion of the total cost is for labor associated } \\
\text { with on-site magnet assembly. Table E.13 provides the labor breakdown for magnets. } \\
\text { Values shown for Tokamak Magnets are calculated in Table E.13. Values shown for Tokamak Operation and Experiments } \\
\text { are calculated in Table E.7. }\end{array}$} \\
\hline
\end{tabular}




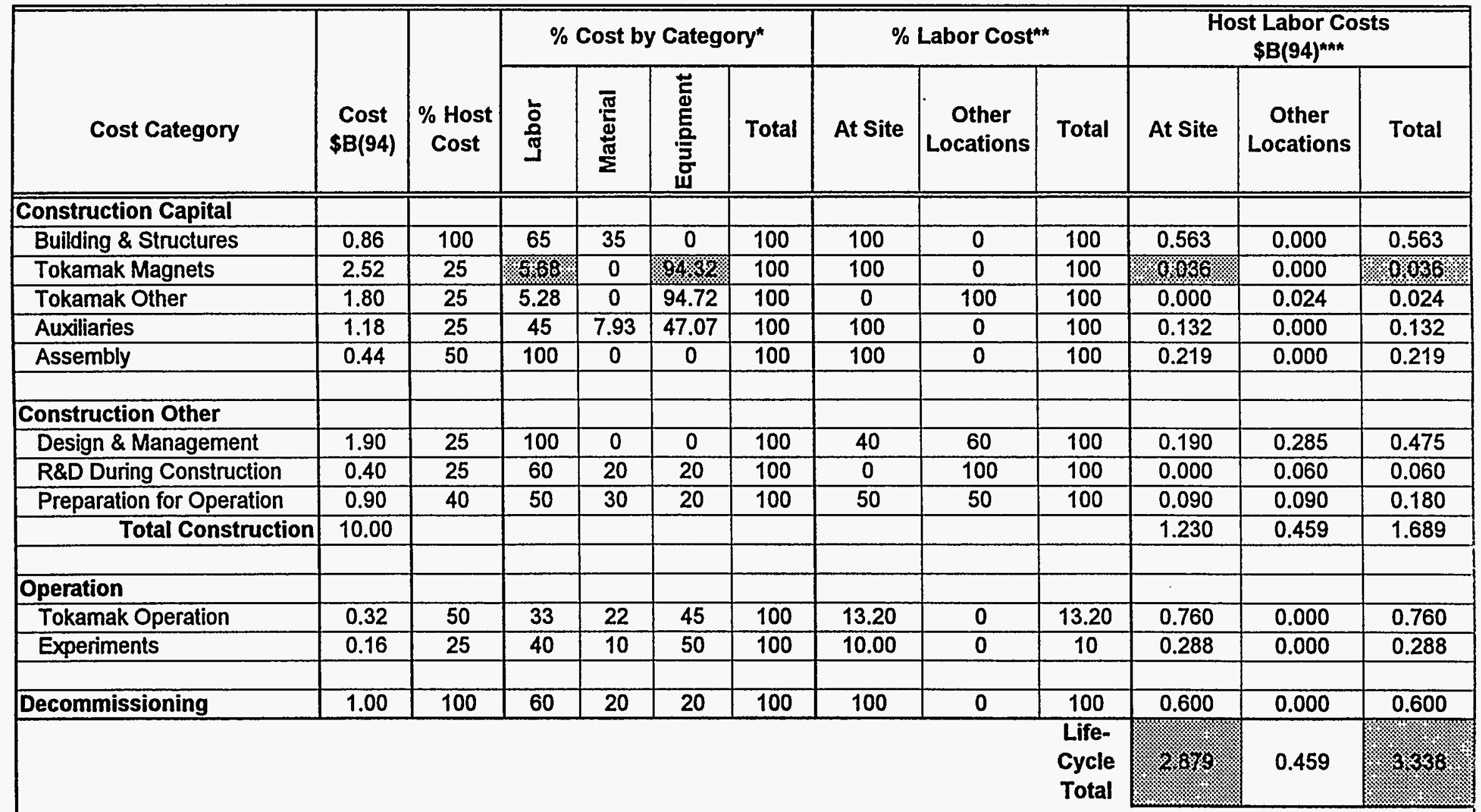

Note: Shaded cells in spreadsheet indicate changes relative to Reference Case.

- 1. Although the overall Labor, Material, and Equipment distribution for "Building and Structures" is shown as $65 \%, 35 \%, 0 \%$, a small portion (approximately $1.4 \%$ ) of the Material cost is labor $(\$ 4.24 \mathrm{M})$. This labor cost is added to the direct labor costs to calculate the total labor costs incurred at the site.

2. The distribution for "Tokamak Magnets" reflects the assumption that a portion of the total cost is for labor associated with on-site magnet assembly. Table E.13 provides the labor breakdown for magnets.

** Values shown for "Tokamak Magnets" are calculated in Table E.13. Values shown for "Tokamak Operation" and "Experiments" are calculated in Table E.7.

Values shown for "Operation" category are for an 18-year operating life. 
TABLE E.18 Annual Labor Costs at Host Site: Magnet Option Case

\begin{tabular}{|c|c|c|c|c|c|}
\hline \multirow[b]{2}{*}{ Year } & \multirow[b]{2}{*}{ Activity* } & \multicolumn{4}{|c|}{ Annual Labor Costs (billions of 1994 dollars) } \\
\hline & & Host Costs & $\begin{array}{c}\text { Non-Host } \\
\text { Costs } \\
\text { (Each Party) }\end{array}$ & $\begin{array}{c}\text { Total } \\
\text { Non-Host } \\
\text { Costs }\end{array}$ & Total \\
\hline 1999 & Construction & 20007 & 00699 & 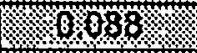 & 101559 \\
\hline 2000 & Construction & 0.666 & $0.20 \%$ & $0 \%$ & 0.287 \\
\hline 2001 & Construction & $10 \% 14$ & 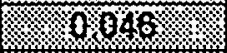 & $10 \%$ & 0,350 \\
\hline 2002 & Construction & 1028 & $00 \% 046$ & $100 \%$ & 6358 \\
\hline 2003 & Construction & 1.6. 666 & .6.5\% & $1.1 \% 26$ & $0.28 \%$ \\
\hline 2004 & Construction & \% 146 & $10 \% 2 \%$ & 60113 & 10334 \\
\hline 2005 & Construction & $20 / 156$ & 0066 & 110.198 & (1349: \\
\hline \multirow[t]{2}{*}{2006} & Construction & (6) & 0 & 1.962 & 0285 \\
\hline & $\begin{array}{l}\text { Total Labor Costs for } \\
\text { Construction } \\
(1999-2006)\end{array}$ & 1.\%. & (1. & : & $\sqrt{1}$ \\
\hline \multirow{2}{*}{$\begin{array}{l}2007 \\
\text { through } \\
2024 \\
\end{array}$} & Operation & 0.0582 & 0.0331 & 0.0994 & 0.1576 \\
\hline & $\begin{array}{l}\text { Total Labor Costs for } \\
\text { Operation } \\
(2007-2024)\end{array}$ & 1.048 & 0.596 & 1.788 & 2.837 \\
\hline \multirow{2}{*}{$\begin{array}{c}2025 \\
\text { through } \\
2028 \\
\end{array}$} & Decommissioning & 0.150 & 0 & 0 & 0.150 \\
\hline & $\begin{array}{l}\text { Total Labor Costs for } \\
\text { Decommissioning } \\
\text { (2025-2028) }\end{array}$ & 0.600 & 0 & 0 & 0.600 \\
\hline \multicolumn{2}{|r|}{ Life-Cycle Total } & 36\% & $0 \%$ & 2055 & $5 \% 334$ \\
\hline
\end{tabular}


TABLE E.19 Host Cost Breakdown by Cost Category: Magnet Option Case

\begin{tabular}{|c|c|c|c|c|c|c|c|c|c|c|}
\hline \multirow[b]{2}{*}{ Cost Category } & \multirow[b]{2}{*}{$\begin{array}{l}\text { Cost } \\
\$ B(94)\end{array}$} & \multirow[b]{2}{*}{$\begin{array}{c}\% \text { Host } \\
\text { Cost }\end{array}$} & \multicolumn{4}{|c|}{$\%$ Cost by Category* } & \multicolumn{3}{|c|}{$\begin{array}{c}\text { Cost by Category } \\
\$ \mathrm{~B}(94)\end{array}$} & \multirow[b]{2}{*}{$\begin{array}{c}\text { Total Host } \\
\text { Cost } \\
\$ B(94)\end{array}$} \\
\hline & & & 京 & $\begin{array}{l}\text { 蹗 } \\
\text { 苟 }\end{array}$ & 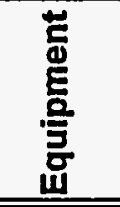 & Total & 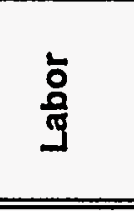 & 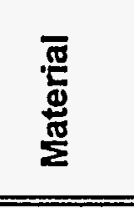 & 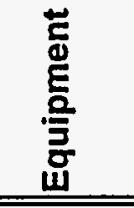 & \\
\hline \multicolumn{11}{|l|}{ Construction Capital } \\
\hline Building \& Structures & 0.860 & 100 & 65 & 35 & 0 & 100 & 0.563 & 0.297 & 0.000 & 0.860 \\
\hline Tokamak Magnets & 2.524 & 25 & $6 \%$ & 0 & 9482 & 100 & 0.036 & 0.000 & 0.595 & 0.631 \\
\hline Tokamak Other & 1.802 & 25 & 5.28 & 0 & 94.72 & 100 & 0.024 & 0.000 & 0.427 & 0.450 \\
\hline Auxiliaries & 1.176 & 25 & 45 & 7.93 & 47.07 & 100 & 0.132 & 0.023 & 0.138 & 0.294 \\
\hline Assembly & 0.438 & 50 & 100 & 0 & 0 & 100 & 0.219 & 0.000 & 0.000 & 0.219 \\
\hline Total & 6.800 & & & & & & \% & 0.320 & 160 & 2.455 \\
\hline & & & & & & & & & & \\
\hline \multicolumn{11}{|l|}{ Construction Other } \\
\hline Design \& Management & 1.900 & 25 & 100 & 0 & 0 & 100 & 0.475 & 0.000 & 0.000 & 0.475 \\
\hline R\&D During Construction & 0.400 & 25 & 60 & 20 & 20 & 100 & 0.060 & 0.020 & 0.020 & 0.100 \\
\hline Preparation for Operation & 0.900 & 40 & 50 & 30 & 20 & 100 & 0.180 & 0.108 & 0.072 & 0.360 \\
\hline Total Construction & 10.000 & & & & & & 1669 & 0.448 & 1252 & 3.390 \\
\hline & & & & & & & & & & \\
\hline \multicolumn{11}{|l|}{ Operation } \\
\hline Tokamak Operation & 0.320 & 50 & 33 & 22 & 45 & 100 & 0.760 & 1.267 & 0.852 & 2.880 \\
\hline Experiments & 0.160 & 25 & 40 & 10 & 50 & 100 & 0.288 & 0.072 & 0.360 & 0.720 \\
\hline Total Operation & & & & & & & 1.048 & 1.339 & 1.212 & 3.600 \\
\hline Decommissioning & 1.000 & 100 & 60 & 20 & 20 & 100 & 0.600 & 0.200 & 0.200 & 1.000 \\
\hline \begin{tabular}{|r|} 
Life-Cycle Total \\
\end{tabular} & & & & & & & 3336 & 1.987 & 28665 & 7.990 \\
\hline \multicolumn{11}{|c|}{$\begin{array}{l}\text { Note: Shaded cells in spreadsheet indicate changes relative to Reference Case. } \\
\text { * 1. Although the overall Labor, Material, and Equipment distribution for "Building and Structures" is shown as } 65 \%, 35 \%, 0 \%, \\
\text { a small portion (approximately } 1.4 \% \text { ) of the Material cost is labor }(\$ 4.24 M) \text {. This labor cost is added to the direct labor } \\
\text { costs to calculate the total labor costs incurred at the site. } \\
\text { 2. The distribution for "Tokamak Magnets" reflects the assumption that a portion of the total cost is for labor associated } \\
\text { with on-site magnet assembly. Table E.13 provides the labor breakdown for magnets. } \\
\text { Values shown for "Tokamak Magnets" are calculated in Table E.13. Values shown for "Tokamak Operation" and "Experiments" } \\
\text { are calculated in Table E.7. } \\
\text { Values shown for "Operation" category are for an 18-year operating life. }\end{array}$} \\
\hline
\end{tabular}




\begin{tabular}{|c|c|c|c|c|c|c|c|}
\hline \multicolumn{8}{|c|}{ 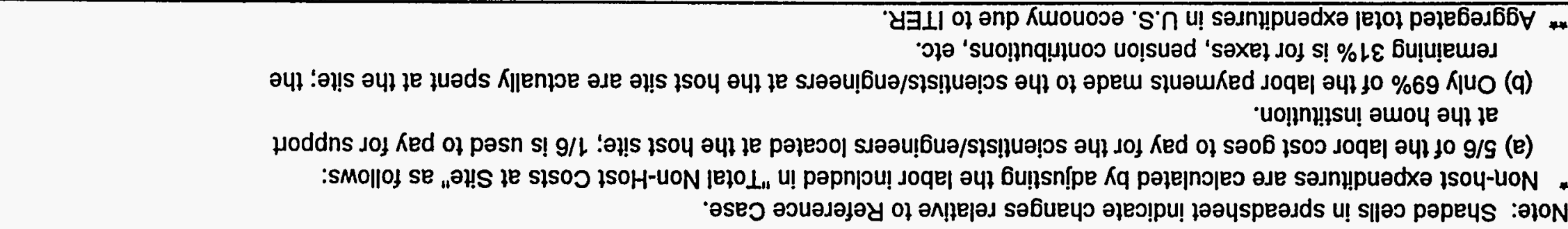 } \\
\hline $788^{\circ} \varepsilon$ & 17.90969. & $1 \%$ & 4 & $18 \%$ & 196 & $066^{\circ} \mathrm{L}$ & 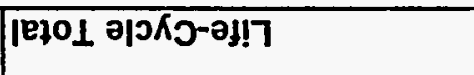 \\
\hline $000^{\circ} 0$ & $000^{\circ} 0$ & $000^{\circ} 0$ & $000 \%$ & $000^{\circ} 0$ & $000^{\circ} 0$ & $000^{\circ} 1$ & Бu!uo!̣ss!̣umojag \\
\hline $089^{\circ} L$ & sltio & S9Z't & $7 \rightarrow 8^{\circ} t$ & tøZ゙ & $\tan 7$ & $000^{\circ} \varepsilon^{\circ}$ & uolyejado pelol \\
\hline $0 Z L O O$ & $96 L^{\circ} 0$ & $D Z S^{\circ} 0$ & $60 \varepsilon^{\prime} L$ & $689^{\circ} 0$ & $798^{\circ} 0$ & $O Z L^{\circ} O$ & 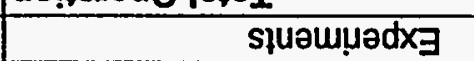 \\
\hline $096^{\circ} 0$ & $612^{\circ} 0$ & $1+\angle L^{\circ} 0$ & $9 \varepsilon \varsigma^{\circ} \varepsilon$ & $999^{\circ} 0$ & $0+l^{\circ}$ & $088^{\prime} \mathrm{Z}$ & uo!̣esado yewexo 1 \\
\hline & & & & & & & uo!nesado \\
\hline & & & & & & & \\
\hline$+0 Z^{\prime} Z$ & ४६<0 & agcion: & $6 \mathrm{Gg}_{\mathrm{g}}$ & W.9. & \% & $06 \varepsilon^{\circ} \varepsilon$ & uo!?onג1suos jełol \\
\hline $081^{\circ} 0$ & $290^{\circ} 0$ & $8211^{\circ} 0$ & SLS'0 & SSLO & $0 L Z^{\prime} 0$ & $09 \varepsilon^{\prime} 0$ & uọnesado dof uọpesedasd \\
\hline $00 L^{\circ} 0$ & $000^{\circ} 0$ & $001^{\circ} 0$ & $001^{\circ} 0$ & $000^{\circ} 0$ & $000^{\circ} 0$ & $00 L^{\prime} 0$ & uo!nonulsuos bu!nna asy \\
\hline$S \angle b^{\circ} 0$ & $601^{\circ} 0$ & $99 \varepsilon^{\circ} 0$ & $808^{\circ} 0$ & $8 Z \varepsilon^{\circ} 0$ & $0 \angle S^{\circ} 0$ & $S \angle T^{\circ} 0$ & JuaməGeuew \& u6ịsad \\
\hline & & & & & & & 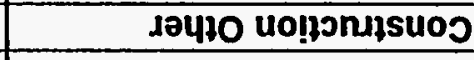 \\
\hline & & & & & & & \\
\hline $6 t t^{\circ} 1$ & 2000 & (1) 98640 & 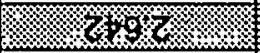 & 6800 & 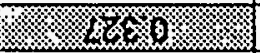 & sstiz & 18101 \\
\hline$\varepsilon \angle 0^{\circ} 0$ & $2 \ngtr 0^{\circ} 0$ & $180^{\circ} 0$ & $S \nrightarrow \varepsilon^{\circ} 0$ & $921^{\circ} 0$ & $612^{\circ} 0$ & $612^{\circ} 0$ & Kiquəss $\forall$ \\
\hline $76 \nearrow^{\circ} 0$ & $000^{\circ} 0$ & $76 Z^{\circ} 0$ & $76 \mathrm{Z}^{\circ} 0$ & $000^{\circ} 0$ & $000^{\circ} 0$ & $\$ 6 Z^{\circ} 0$ & səụe!!!xn \\
\hline $096^{\circ} 0$ & $000^{\circ} 0$ & OSt'0 & ost:0 & $000^{\circ} 0$ & $000^{\circ} 0$ & $09 t^{\circ} 0$ & ЈәчңО ҮЕயеуо \\
\hline $189^{\circ} 0$ & 12200 & 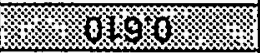 & 1.6960 & (2900 & 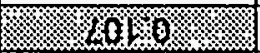 & $189^{\circ} 0$ & spaubew yeuexo1 \\
\hline $000^{\circ} 0$ & $000^{\circ} 0$ & $000^{\circ} 0$ & $098^{\circ} 0$ & $000^{\circ} 0$ & $000^{\circ} 0$ & $098^{\circ} 0$ & Səدnłonlı \& 6u!p!!ng \\
\hline & & & & & & & 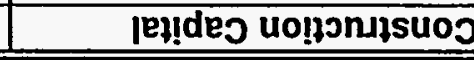 \\
\hline $\begin{array}{c}\text { sisos } \\
\text { s'n } 18 j 01\end{array}$ & 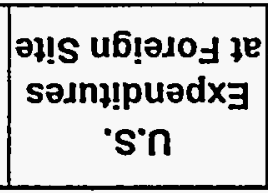 & $\begin{array}{c}\text { 's'n u! } \\
\text { sədnł!puədx } \\
\text { 's'n }\end{array}$ & 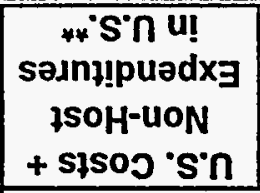 & 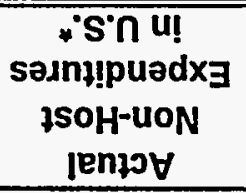 & $\begin{array}{c}\text { əl!S } \\
\text { 7soH le słsos } \\
\text { ISOH-UON } \\
\text { jełOL }\end{array}$ & $\begin{array}{c}\text { słsoj } \\
\text { s'n IEjOL }\end{array}$ & \multirow[t]{2}{*}{ 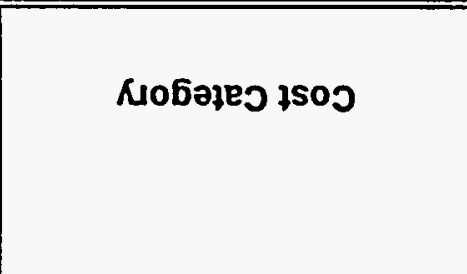 } \\
\hline \multicolumn{3}{|c|}{ 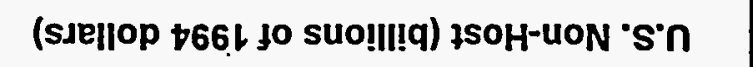 } & \multicolumn{4}{|c|}{ (suellop t66 jo suo!l!!) isoH 's'n } & \\
\hline
\end{tabular}


TABLE E.21 Host/Non-Host Funding and Spending Assumptions: Increased Non-Host Participation Case

\begin{tabular}{|c|c|c|c|c|c|c|}
\hline \multirow[b]{2}{*}{ Cost Category } & \multirow[b]{2}{*}{$\%$ Host Cost } & \multicolumn{3}{|c|}{$\%$ Non-Host Cost (Each Party) } & \multirow[b]{2}{*}{$\begin{array}{c}\text { Total } \% \\
\text { Non-Host } \\
\text { Cost }\end{array}$} & \multirow[b]{2}{*}{ Total \% } \\
\hline & & $\begin{array}{l}\text { At Host } \\
\text { Site }\end{array}$ & $\begin{array}{c}\text { At } \\
\text { Home }\end{array}$ & Total & & \\
\hline \multicolumn{7}{|l|}{ Construction Capital } \\
\hline Building \& Structures & 100 & 0 & 0 & 0 & 0 & 100 \\
\hline Tokamak Magnets ${ }^{\star}$ & 25 & 5.28 & 19.72 & 25 & 75 & 100 \\
\hline Tokamak Other & 25 & 0 & 25 & 25 & 75 & 100 \\
\hline Auxiliaries & 25 & 0 & 25 & 25 & 75 & 100 \\
\hline Assambly & 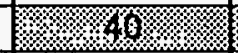 & 20 & 0 & $20 \%$ & 60. & 100 \\
\hline \multicolumn{7}{|l|}{ Construction Other } \\
\hline Design \& Management & 25 & 10 & 15 & 25 & 75 & 100 \\
\hline R\&D During Construction & 25 & 0 & 25 & 25 & 75 & 100 \\
\hline Preparation for Operation & 40 & 10 & 10 & 20 & 60 & 100 \\
\hline \multicolumn{7}{|l|}{ Operation (per year) ${ }^{\star \star}$} \\
\hline Tokamak Operation & 50 & 6.60 & 10.07 & 16.67 & 50 & 100 \\
\hline Experiments & 25 & 10.00 & 15.00 & 25.00 & 75 & 100 \\
\hline Decommissioning & $76 \%$ & 6 & 0 & 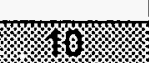 & 30 & 100 \\
\hline $\begin{array}{l}\text { Note: Shaded cells in sprea } \\
\text { Each party is responsible } \\
\text { designated as labor for } n \\
\text { the host site for labor is } \\
\text { Non-host costs for "Toka } \\
\text { at home are calculated i }\end{array}$ & $\begin{array}{l}\text { licate changes } \\
\text { of the total cost } \\
\text { sembly at the } h \\
\text { in Table E.4. } \\
\text { ation" and "Exp } \\
7 .\end{array}$ & $\begin{array}{l}\text { relative to } R \\
\text { of the mag } \\
\text { ost site. Th } \\
\text { eriments" in }\end{array}$ & $\begin{array}{l}\text { eference } \\
\text { ets. A p } \\
\% \text { non- } \\
\text { curred at }\end{array}$ & $\begin{array}{l}\text { se. } \\
\text { on of this } \\
\text { t cost inct } \\
\text { host site }\end{array}$ & $\begin{array}{l}\text { cost is } \\
\text { urred at } \\
\text { and }\end{array}$ & \\
\hline
\end{tabular}


TABLE E.22 Summary of Host and Non-Host Life-Cycle Costs: Increased Non-Host Participation Case

\begin{tabular}{|c|c|c|c|c|c|c|c|c|}
\hline \multirow[b]{3}{*}{ Cost Category } & \multicolumn{8}{|c|}{ Life-Cycle Costs (billions of 1994 dollars) } \\
\hline & \multirow[b]{2}{*}{$\begin{array}{l}\text { Host } \\
\text { Cost }\end{array}$} & \multicolumn{3}{|c|}{-Non-Host Cost (Each Party) } & \multicolumn{3}{|c|}{ Total Non-Host Cost } & \multirow[b]{2}{*}{$\begin{array}{l}\text { Total } \\
\text { Cost } \\
\end{array}$} \\
\hline & & $\begin{array}{l}\text { At.Host } \\
\text { Site }^{\star}\end{array}$ & $\begin{array}{c}\text { At } \\
\text { Home }\end{array}$ & Total & $\begin{array}{l}\text { At Host } \\
\text { Site* }\end{array}$ & $\begin{array}{c}\text { At } \\
\text { Home }\end{array}$ & Total & \\
\hline \multicolumn{9}{|l|}{ Construction Capital } \\
\hline Building \& Structures & 0.860 & 0 & 0 & 0 & 0 & 0 & 0 & 0.860 \\
\hline Tokamak Magnets & 0.631 & 0.133 & 0.498 & 0.631 & 0.400 & 1.49 & 1.893 & 2.524 \\
\hline Tokamak Other & 0.450 & 0.000 & 0.450 & 0.450 & 0.000 & 1.35 & 1.351 & 1.802 \\
\hline Auxiliaries & 0.294 & 0.000 & 0.294 & 0.294 & 0.000 & 0.88 & 0.882 & 1.176 \\
\hline Assembly & 0.155 & 0.0880 & 0.000 & $0808 \%$ & 0.263 & 0.00 & (50. & 0.438 \\
\hline Total & $24 \times 14$ & 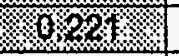 & 1.242 & 166 & 06663 & 3.726 & 4309 & 6.800 \\
\hline & & & & & & & & \\
\hline \multicolumn{9}{|l|}{ Construction Other } \\
\hline Design \& Management & 0.475 & 0.190 & 0.285 & 0.475 & 0.570 & 0.86 & 1.425 & 1.900 \\
\hline R\&D During Construction & 0.100 & 0.000 & 0.100 & 0.100 & 0.000 & 0.30 & 0.300 & 0.400 \\
\hline Preparation for Operation & 0.360 & 0.090 & 0.090 & 0.180 & 0.270 & 0.27 & 0.540 & 0.900 \\
\hline Total Construction & 3.346 & 0.501 & 1.717 & 2.218 & 1.503 & 5.151 & 6.654 & 10.00 \\
\hline \multicolumn{8}{|l|}{ Operation } & \\
\hline Tokamak Operation & 2.880 & 0.380 & 0.580 & 0.960 & 1.140 & 1.740 & 2.880 & 5.760 \\
\hline Experiments & 0.720 & 0.288 & 0.432 & 0.720 & 0.864 & 1.296 & 2.160 & 2.880 \\
\hline Decommissioning & 080. & $3010 \%$ & 0.00 & 0.6 & 1000 & 0.00 & $60,30 \%$ & 1.00 \\
\hline & & & & & & & & \\
\hline Total & 16646 & 1269 & 2.729 & $8 / 998 \%$ & $\% 36 \%$ & 8.187 & 10994 & 19.64 \\
\hline$\%$ Total Cost & $38 \% 5 \%$ & $6.6 \% \%$ & $13.89 \%$ & $20 \times 36 \%$ & 16. $1 \%$ & $41.68 \%$ & $6 \% 07 \%$ & \\
\hline
\end{tabular}


TABLE E.23 Host/Non-Host Annual Costs: Increased Non-Host Participation Case

\begin{tabular}{|c|c|c|c|c|c|c|c|c|c|}
\hline \multirow[b]{3}{*}{ Year } & \multirow[b]{3}{*}{ Activity* } & \multicolumn{8}{|c|}{ Annual Costs (billions of 1994 dollars) } \\
\hline & & \multirow[b]{2}{*}{ Host Costs } & \multicolumn{3}{|c|}{ Non-Host Costs (Each Party) } & \multicolumn{3}{|c|}{ Total Non-Host Costs } & \multirow[b]{2}{*}{ Total Costs } \\
\hline & & & $\begin{array}{l}\text { At Host } \\
\text { Site }^{\star \star *}\end{array}$ & $\begin{array}{c}\text { At } \\
\text { Home }\end{array}$ & Total & $\begin{array}{l}\text { At Host } \\
\text { Site }^{\star \star}\end{array}$ & $\begin{array}{c}\text { At } \\
\text { Home }\end{array}$ & Total & \\
\hline 1999 & Construction & 100102 & $00035 \%$ & 0.110 & $00145 \%$ & 0104 & 0.331 & $0,0,35 \%$ & 0.628 \\
\hline 2000 & Construction & $1 \% \div 04433 \% \%$ & $100057 \%$ & 0.234 & 0 \% & $006 \% 1$ & 0.703 & $0.87 \%$ & 1.308 \\
\hline 2001 & Construction & \%. & 1\%0068\% & 0.297 & 6.6.36\% & (3.26\% & 0.890 & 10093 & 1.648 \\
\hline 2002 & Construction & $0554 \%$ & $10.068 \%$ & 0.297 & 0.364 & 10640 & 0.890 & 11093 & 1.648 \\
\hline 2003 & Construction & 04433 & 10.65 & 0.234 & $60 \% 911$ & $0 \%$ & 0.703 & 10874 & 1.308 \\
\hline 2004 & Construction & 10.4211 .2$. & 00673 & 0.199 & (6.3. & 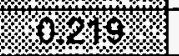 & 0.598 & $608 \%$ & 1.238 \\
\hline 2005 & Construction & (19439 & (6. & 0.204 & 6/ 8 \% & 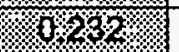 & 0.612 & 6o, 84 & 1.283 \\
\hline \multirow[t]{2}{*}{2006} & Construction & $1.10 \%$ & 10066 & 0.142 & 1056 & $9.699 \%$ & 0.425 & 10624 & 0.943 \\
\hline & $\begin{array}{c}\text { Total Construction } \\
\text { Expenditures } \\
(1999-2006) \\
\end{array}$ & 1918 : & 1. & 1.717 & $\sqrt{1.2}$ & $.850 \%$ & 5.151 & (4. & 10.000 \\
\hline \multirow{2}{*}{$\begin{array}{c}2007 \\
\text { through } \\
2024 \\
\end{array}$} & Operation & 0.200 & 0.037 & 0.056 & 0.093 & 0.111 & 0.169 & 0.280 & 0.480 \\
\hline & $\begin{array}{l}\text { Total Operating } \\
\text { Expenditures } \\
(2007-2024)\end{array}$ & 3.600 & 0.668 & 1.012 & 1.680 & 2.004 & 3.036 & 5.040 & 8.640 \\
\hline \multirow[t]{2}{*}{$\begin{array}{c}2025 \\
\text { through } \\
2028 \\
\end{array}$} & Decommissioning & 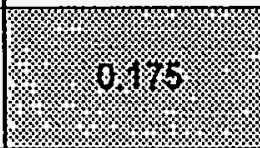 & $(0.965$ & 0.000 & $\frac{1}{9625}$ & $\sqrt{1}$ & 0.000 & $80,0 \%$ & 0.250 \\
\hline & $\begin{array}{c}\text { Total } \\
\text { Decommissioning } \\
\text { Expenditures } \\
(2025-2028)\end{array}$ & (1. & : & 0.000 & 0.900 & $\sqrt{8.306}$ & 0.000 & : & 1.000 \\
\hline $\begin{array}{l}\text { Note: She } \\
\text { * Constru } \\
* \text { Actual } \\
\text { contribt }\end{array}$ & $\begin{array}{l}\text { ded cells in spreadsh } \\
\text { ction includes Constr } \\
\text { expenditures at the ho } \\
\text { tions, and other facto }\end{array}$ & $\begin{array}{l}\text { eet indicate chan } \\
\text { ction Capital and } \\
\text { st site are lower } \\
\text { rs. Table E.28 pr }\end{array}$ & $\begin{array}{l}\text { ges relative } \\
\text { Constructio } \\
\text { than the val } \\
\text { rovides actu }\end{array}$ & $\begin{array}{l}\text { o Refere } \\
\text { Other c } \\
\text { es showr } \\
\text { I non-hos }\end{array}$ & $\begin{array}{l}\text { Case. } \\
\text { ts. } \\
\text { ue to sup } \\
\text { expenditu }\end{array}$ & $\begin{array}{l}\text { It costs, ta } \\
\text { in the hos }\end{array}$ & Ixes, pe & Total & 19.64 \\
\hline
\end{tabular}


TABLE E.24 Non-Host Spending Assumptions for Labor at Host Site: Increased Non-Host Participation Case

\begin{tabular}{|c|c|c|c|c|c|c|c|c|c|c|}
\hline \multirow[b]{2}{*}{ Cost Category } & \multirow[b]{2}{*}{$\begin{array}{l}\text { Cost } \\
\$ B(94)\end{array}$} & \multicolumn{4}{|c|}{$\%$ Cost by Category* } & \multicolumn{3}{|c|}{$\begin{array}{l}\% \text { Non-Host Cost } \\
\text { (Each Party) }^{\star \star}\end{array}$} & \multicolumn{2}{|c|}{$\begin{array}{c}\text { Non-Host Labor } \\
\text { At Host Site \$B(94) }\end{array}$} \\
\hline & & $\begin{array}{l}\frac{0}{0} \\
\text { J } \\
\end{array}$ & 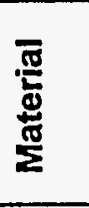 & 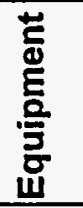 & Total & $\begin{array}{l}\text { At Host } \\
\text { Site }\end{array}$ & $\begin{array}{c}\text { At } \\
\text { Home }\end{array}$ & Total & Each Party & $\begin{array}{c}\text { Total All } \\
\text { Non-Host } \\
\text { Parties }\end{array}$ \\
\hline \multicolumn{11}{|l|}{ Construction Capital } \\
\hline Building \& Structures & 0.86 & 65 & 35 & 0 & 100 & 0 & 0 & $\overline{0}$ & 0.000 & 0.000 \\
\hline Tokamak Magnets & 2.52 & 21 & 0. & 79 & 100 & 5.28 & 19.72 & 25 & 0.133 & 0.400 \\
\hline Tokamak Other & 1.80 & 0 & 0 & 100 & 100 & 0 & 25 & 25 & 0.000 & 0.000 \\
\hline Auxiliaries & 1.18 & 45 & 0 & 55 & 100 & 0 & 25 & 25 & 0.000 & 0.000 \\
\hline Assembly & 0.44 & 100 & 0 & 0 & 100 & 26 & 0 & 20 & \%ovo6. & 026 \\
\hline \multicolumn{10}{|l|}{ Construction Othier } & \\
\hline Design \& Management & 1.90 & 100 & 0 & 0 & 100 & 10 & 15 & 25 & 0.190 & 0.570 \\
\hline R\&D During Construction & 0.40 & 60 & 20 & 20 & 100 & 0 & 25 & 25 & 0.000 & 0.000 \\
\hline Preparation for Operation & 0.90 & 50 & 30 & 20 & 100 & 10 & 10 & 20 & 0.090 & 0.270 \\
\hline Total Construction & 10.00 & & & & & & & & 6501 & 1503 \\
\hline & & & & & & & & & & \\
\hline \multicolumn{11}{|l|}{ Operation (per year) } \\
\hline Tokamak Operation & 0.32 & 33 & 22 & 45 & 100 & 6.60 & 10.07 & 16.67 & 0.380 & 1.140 \\
\hline Experiments & 0.16 & 40 & 10 & 50 & 100 & 10.00 & 15.00 & 25 & 0.216 & 0.648 \\
\hline Decommissioning & 1.00 & 60 & 20 & 20 & 100 & 10 & 0 & 10 & (6) $00 \%$ & 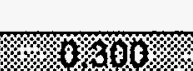 \\
\hline & & & & & & & & $\begin{array}{l}\text { Life- } \\
\text { Cycle } \\
\text { Total }\end{array}$ & ?: & $8 \times 58$ \\
\hline \multicolumn{11}{|c|}{$\begin{array}{l}\text { Note: Shaded cells in spreadsheet indicate changes relative to Reference Case. } \\
\text { A. Although the Tokamak Magnets are shown as } 100 \% \text { equipment, a portion of the total cost is for labor associated } \\
\text { with on-site magnet assembly. Table E.4 provides the labor breakdown for magnets. } \\
\text { Values shown for Tokamak Magnets are calculated in Table E.4. Values shown for Tokamak Operation and Experiments } \\
\text { are calculated in Table E.7. Entire non-host contribution for decommissioning is for labor at host site. } \\
\text { Values shown for operation are for an 18-year operating life. }\end{array}$} \\
\hline
\end{tabular}


TABLE E.25 Host Spending Assumptions for Labor at Host Site: Increased Non-Host Participation Case

\begin{tabular}{|c|c|c|c|c|c|c|c|c|c|c|c|c|}
\hline \multirow[b]{2}{*}{ Cost Category } & \multirow[b]{2}{*}{$\begin{array}{l}\text { Cost } \\
\$ B(94)\end{array}$} & \multirow[b]{2}{*}{$\begin{array}{c}\% \text { Host } \\
\text { Cost }\end{array}$} & \multicolumn{4}{|c|}{$\%$ Cost by Category } & \multicolumn{3}{|c|}{$\%$ Labor Cost ${ }^{* \star}$} & \multicolumn{3}{|c|}{$\begin{array}{c}\text { Host Labor Costs } \\
\$ B(94)^{\star \star \star}\end{array}$} \\
\hline & & & 占 & 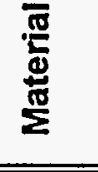 & 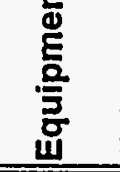 & Total & At Site & $\begin{array}{c}\text { Other } \\
\text { Locations }\end{array}$ & Total & At Site & $\begin{array}{c}\text { Other } \\
\text { Locations }\end{array}$ & Total \\
\hline \multicolumn{13}{|l|}{ Construction Capital } \\
\hline Building \& Structures & 0.86 & 100 & 65 & 35 & 0 & 100 & 100 & 0 & 100 & 0.563 & 0.000 & 0.563 \\
\hline Tokamak Magnets & 2.52 & 25 & 21.13 & 0 & 78.87 & 100 & 100 & 0 & 100 & 0.133 & 0.000 & 0.133 \\
\hline Tokamak Other & 1.80 & 25 & 5.28 & 0 & 94.72 & 100 & 0 & 100 & 100 & 0.000 & 0.024 & 0.024 \\
\hline Auxiliaries & 1.18 & 25 & 45 & 7.93 & 47.07 & 100 & 100 & 0 & 100 & 0.132 & 0.000 & 0.132 \\
\hline Assembly & 0.44 & 40 & 100 & 0 & 0 & 100 & 100 & 0 & 100 & 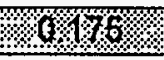 & 0.000 & 0.17\$ \\
\hline \multicolumn{13}{|l|}{ Construction Other } \\
\hline Design \& Management & 1.90 & 25 & 100 & 0 & 0 & 100 & 40 & 60 & 100 & 0.190 & 0.285 & 0.475 \\
\hline R\&D During Construction & 0.40 & 25 & 60 & 20 & 20 & 100 & 0 & 100 & 100 & 0.000 & 0.060 & 0.060 \\
\hline Preparation for Operation & 0.90 & 40 & 50 & 30 & 20 & 100 & 50 & 50 & 100 & 0.090 & 0.090 & 0.180 \\
\hline Total Construction & 10.00 & & & & & & & & & 4284 & 0.459 & $1 / 243$ \\
\hline & & & & & & & & & & & & \\
\hline \multicolumn{13}{|l|}{ Operation } \\
\hline Tokamak Operation & 0.32 & 50 & 33 & 22 & 45 & 100 & 13.20 & 0 & 13.20 & 0.760 & 0.000 & 0.760 \\
\hline Experiments & 0.16 & 25 & 40 & 10 & 50 & 100 & 10.00 & 0 & 10 & 0.288 & .0 .000 & 0.288 \\
\hline Decommissioning & 1.00 & 70 & 60 & 20 & 20 & 100 & 100 & 0 & 100 & 60360 & 0.000 & $0 \times 000$ \\
\hline & & & & & & & & & $\begin{array}{l}\text { Life- } \\
\text { Cycle } \\
\text { Total }\end{array}$ & (1. & 0.459 & 909 \\
\hline
\end{tabular}

Note: Shaded cells in spreadsheet indicate changes relative to Reference Case.

* 1. Athough the overall Labor, Material, and Equipment distribution for "Building and Structures" is shown as $65 \%, 35 \%, 0 \%$, a small portion (approximately $1.4 \%$ ) of the Material cost is labor ( $\$ 4.24 \mathrm{M})$. This labor cost is added to the direct labor costs to calculate the total labor costs incurred at the site.

2. The distribution for "Tokamak Magnets" reflects the assumption that a portion of the total cost is for labor associated with on-site magnet assembly. Table E.4 provides the labor breakdown for magnets.

*t Values shown for "Tokamak Magnets" are calculated in Table E.4. Values shown for "Tokamak Operation" and "Experiments" are calculated in Table E.7.

*alues shown for "Operation" category are for an 18-year operating life. 
TABLE E.26 Annual Labor Costs at Host Site: Increased Non-Host Participation Case

\begin{tabular}{|c|c|c|c|c|c|}
\hline \multirow[b]{2}{*}{ Year } & \multirow[b]{2}{*}{ Activity* } & \multicolumn{4}{|c|}{ Annual Labor Costs (billions of 1994 dollars) } \\
\hline & & Host Costs & $\left|\begin{array}{c}\text { Non-Host } \\
\text { Costs } \\
\text { (Each Party) }\end{array}\right|$ & $\begin{array}{c}\text { Total } \\
\text { Non-Host } \\
\text { Costs }\end{array}$ & Total \\
\hline 1999 & Construction & (907\% & 00035 & 6 & 0.178 \\
\hline 2000 & Construction & 80.64 & 1.60 & $6 \%$ & 0.345 \\
\hline 2001 & Construction & m. & 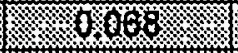 & 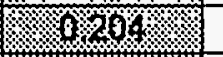 & 0.428 \\
\hline 2002 & Construction & $6 \% 25$ & 70068 & $16020 \%$ & 0.428 \\
\hline 2003 & Construction & $0 \%$ & 196 & 事 & 0.345 \\
\hline 2004 & Construction & 00.41 & 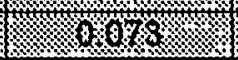 & $2.6 \%$ & 0.370 \\
\hline 2005 & Construction & 60 & $60.01 \%$ & 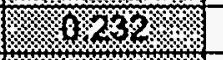 & 0.388 \\
\hline \multirow[t]{2}{*}{2006} & Construction & 0.105 & 10.066. & . $68 \% 9$. & 0.304 \\
\hline & $\begin{array}{l}\text { Total Labor Costs for } \\
\text { Construction } \\
(1999-2006)\end{array}$ & $\sqrt{2} x^{8}$ & 9.69 & $1 \%$ & 2.787 \\
\hline \multirow{2}{*}{$\begin{array}{c}2007 \\
\text { through } \\
2024 \\
\end{array}$} & Operation & 0.0582 & 0.0331 & 0.0994 & 0.1576 \\
\hline & $\begin{array}{l}\text { Total Labor Costs for } \\
\text { Operation } \\
(2007-2024)\end{array}$ & 1.048 & 0.596 & 1.788 & 2.837 \\
\hline \multirow[t]{2}{*}{$\begin{array}{c}2025 \\
\text { through } \\
2028 \\
\end{array}$} & Decommissioning & 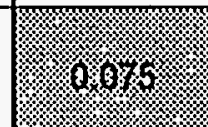 & 8.8 .825 & : & 0.150 \\
\hline & $\begin{array}{l}\text { Total Labor Costs for } \\
\text { Decommissioning } \\
(2025-2028)\end{array}$ & 9080 & 40 & 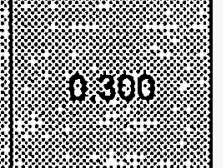 & 0.600 \\
\hline \multicolumn{2}{|r|}{ Life-Cycle Total } & 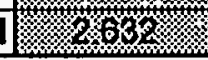 & $1 \%$ & $1 \% 3691 \% 4$ & 6.224 \\
\hline
\end{tabular}




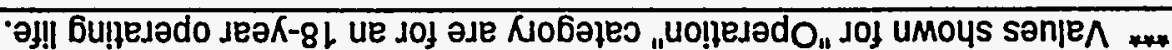
$\angle \ni \exists$ әjqe $\perp$ u! pəjeinojeo ase

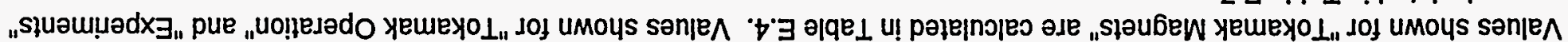

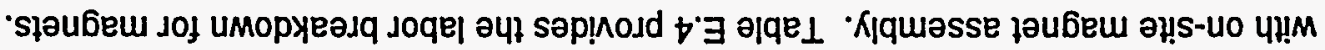

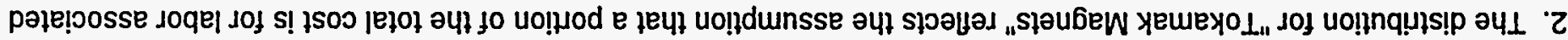

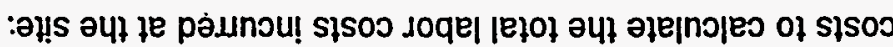

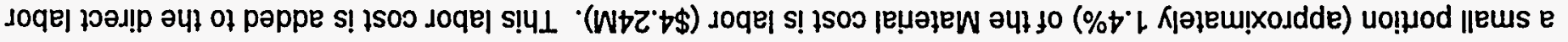

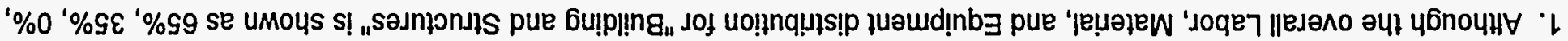

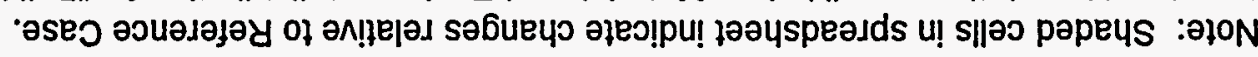

\begin{tabular}{|c|c|c|c|c|c|c|c|c|c|c|}
\hline $90 \% \%$ & $\angle 9 S^{\prime} Z$ & $\angle 86^{\circ} \mathrm{L}$ & 66010. & & & & & & & 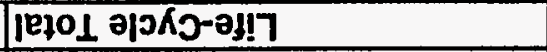 \\
\hline 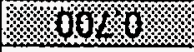 & $00 Z^{\circ} 0$ & $00 Z^{\circ} 0$ & 0 & 001 & $0 Z$ & 02 & 09 & 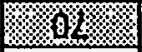 & $000^{\circ} \mathrm{L}$ & bu!uo!ss!mumoəəd \\
\hline & & & & & & & & & & \\
\hline $009^{\circ} \varepsilon$ & こІご & $6 \varepsilon \varepsilon^{\circ} \downarrow$ & $870^{\circ} \mathrm{L}$ & & & & & & & uolpedodo jejol \\
\hline $0 Z L^{\circ} 0$ & $09 \varepsilon^{\circ} 0$ & $2 \angle 0^{\circ} 0$ & $882^{\circ} 0$ & 001 & $0 S$ & 아 & ot & $\mathbf{s Z}$ & $091^{\circ} 0$ & spuamụədx \\
\hline \multirow[t]{2}{*}{$088^{\circ} Z$} & $298^{\circ} 0$ & $\angle 9 Z^{\prime} L$ & $09 \angle 0$ & 001 & St & $2 Z$ & $\varepsilon \varepsilon$ & 09 & $0 Z \varepsilon^{\circ} 0$ & uo!̣esədo yemexo $\perp$ \\
\hline & & & & & & & & & & uo!̣esədo \\
\hline & & & & & & & & & & \\
\hline $9+\varepsilon^{\circ} \varepsilon$ & SSLL & $8 \nabla t 0$ & $\varepsilon \gg L$ & & & & & & $000^{\circ} \mathrm{Ol}$ & uo!fond\}suos lejol \\
\hline $09 \varepsilon^{\circ} 0$ & $2 \angle 0^{\circ} 0$ & $801^{\circ} 0$ & $081^{\circ} 0$ & $00 \mathrm{~L}$ & 02 & $0 \varepsilon$ & 09 & $0 t$ & $006^{\circ} 0$ & uoljesado sol uo!nejededd \\
\hline 0010 & $020^{\circ} 0$ & $020^{\circ} 0$ & $090^{\circ} 0$ & 001 & $0 Z$ & $0 Z$ & 09 & $\mathcal{G Z}$ & $00 t^{\circ} 0$ & uo!̣onjłsuos bupna asy \\
\hline \multirow[t]{2}{*}{$S L D^{\circ} 0$} & $000^{\circ} 0$ & $000^{\circ} 0$ & SLOO & 001 & 0 & 0 & 001 & $\mathbf{S Z}$ & $006^{\circ} 1$ & 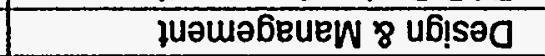 \\
\hline & & & & & & & & & & Jә410 Uo!fonגisuog \\
\hline & & & & & & & & & & \\
\hline $1+\bullet 2$ & $\varepsilon 90^{\circ} \mathrm{L}$ & $0 Z \varepsilon^{\circ} 0$ & $820 \%$ & & & & & & $008^{\prime} 9$ & $1 \mathrm{e} 301$ \\
\hline 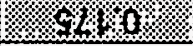 & $000^{\circ} 0$ & $000^{\circ} 0$ & 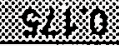 & 001 & 0 & 0 & 001 & 36 & $8 \varepsilon \nabla^{\circ} 0$ & Klquess $\forall$ \\
\hline $762^{\circ} 0$ & $8 \varepsilon l^{\circ} 0$ & $\varepsilon 20^{\circ} 0$ & $2 \varepsilon l^{\circ} 0$ & 001 & $\angle 0^{\circ} \angle B$ & $\varepsilon 6 . \mathrm{L}$ & st & 92 & $9 \angle L^{\circ}$ & sẹue!! $x \cap \forall$ \\
\hline 0960 & $\angle Z D^{\circ} O$ & $000^{\circ} 0$ & $\$ 20^{\circ} 0$ & 001 & $2 L \triangleright 76$ & 0 & $82^{\prime} 9$ & $s 2$ & $208^{\circ} 1$ & 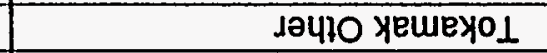 \\
\hline $189^{\circ} 0$ & $86 t^{\circ} 0$ & $000^{\circ} 0$ & $\varepsilon \varepsilon \vdash^{\circ} 0$ & 001 & $\angle 8^{\circ} 8 L$ & 0 & $\varepsilon l^{\circ} L$ & $s 2$ & $\nabla 29 \cdot 2$ & Słau6ew yeurexo 1 \\
\hline \multirow[t]{2}{*}{$098^{\circ} 0$} & $000^{\circ} 0$ & $\angle 6 Z^{\prime} 0$ & $899^{\circ} 0$ & 001 & 0 & $S \varepsilon$ & 59 & 001 & $098^{\circ} 0$ & 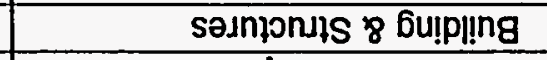 \\
\hline & & & & & & & & & & ןeu!deo uo!zonגsuoJ \\
\hline \multirow[t]{2}{*}{ 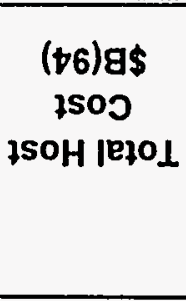 } & 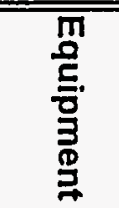 & $\begin{array}{l}3 \\
\frac{3}{0} \\
\frac{\overline{0}}{0} \\
\underline{0}\end{array}$ & $\begin{array}{l}5 \\
0 \\
g \\
g\end{array}$ & |ejOL & 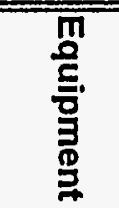 & 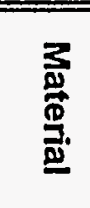 & $\begin{array}{l}\frac{5}{2} \\
\frac{0}{0} \\
0\end{array}$ & \multirow[t]{2}{*}{$\begin{array}{l}\text { 1500 } \\
\text { tSOH } \%\end{array}$} & \multirow[t]{2}{*}{$\begin{array}{c}(76) 9 \$ \\
7500\end{array}$} & \multirow[t]{2}{*}{ К⿴囗бәреว isoว } \\
\hline & ${ }_{* 4} \times 1$ & 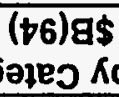 & & \multicolumn{4}{|c|}{ 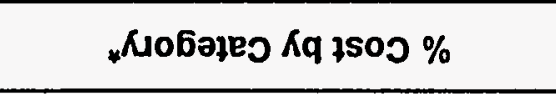 } & & & \\
\hline
\end{tabular}

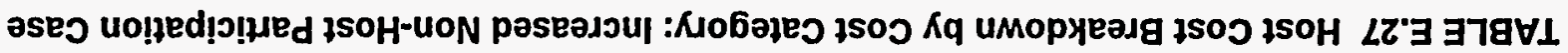


TABLE E.28 U.S. Host Versus U.S. Non-Host Cost Comparison: Increased Non-Host Participation Case

\begin{tabular}{|c|c|c|c|c|c|c|c|}
\hline \multirow[b]{2}{*}{ Cost Category } & \multicolumn{4}{|c|}{ U.S. Host (billions of 1994 dollars) } & \multicolumn{3}{|c|}{ U.S. Non-Host (billions of 1994 dollars) } \\
\hline & $\begin{array}{l}\text { Total U.S. } \\
\text { Costs }\end{array}$ & $\begin{array}{c}\text { Total } \\
\text { Non-Host } \\
\text { Costs at Host } \\
\text { Site. } \\
\end{array}$ & $\begin{array}{c}\text { Actual } \\
\text { Non-Host } \\
\text { Expenditures } \\
\text { in U.S.* }\end{array}$ & $\begin{array}{c}\text { U.S. Costs + } \\
\text { Non-Host } \\
\text { Expenditures } \\
\text { in U.S. }{ }^{\star \star}\end{array}$ & $\begin{array}{l}\text { U.S. } \\
\text { Expenditures } \\
\text { in U.S. }\end{array}$ & $\begin{array}{c}\text { U.S. } \\
\text { Expenditures } \\
\text { at Foreign Site }\end{array}$ & $\begin{array}{l}\text { Total U.S. } \\
\text { Costs }\end{array}$ \\
\hline \multicolumn{8}{|l|}{ Construction Capital } \\
\hline Building \& Structures & 0.860 & 0.000 & 0.000 & 0.860 & 0.000 & 0.000 & 0.000 \\
\hline Tokamak Magnets & 0.631 & 0.400 & 0.230 & 0.861 & 0.554 & 0.077 & 0.631 \\
\hline Tokamak Other & $0 . \overline{450}$ & 0.000 & 0.000 & 0.450 & 0.450 & 0.000 & 0.450 \\
\hline Auxiliaries & 0.294 & 0.000 & 0.000 & 0.294 & 0.294 & 0.000 & 0.294 \\
\hline Assembly & (6.1. & 0.153 & WOKSY & 0.326 & $0003 \%$ & $0.056 \%$ & $0088 \%$ \\
\hline Total & 2.411 & 0.663 & 0.381 & 2.792 & 1.336 & 0.127 & 1.463 \\
\hline \multirow{2}{*}{\multicolumn{8}{|c|}{ Construction Other }} \\
\hline & & & & & & & \\
\hline Design \& Management & 0.475 & 0.570 & 0.328 & 0.803 & 0.366 & 0.109 & 0.475 \\
\hline R\&D During Construction & 0.100 & 0.000 & 0.000 & 0.100 & 0.100 & 0.000 & 0.100 \\
\hline Preparation for Operation & 0.360 & 0.270 & 0.155 & 0.515 & 0.128 & 0.052 & 0.180 \\
\hline Total Construction & 3.346 & 1.503 & 0.864 & 4.210 & 1.930 & 0.288 & 2.218 \\
\hline \multicolumn{8}{|l|}{ Operation } \\
\hline Tokamak Operation & 2.880 & 1.140 & 0.656 & 3.536 & 0.741 & 0.219 & 0.960 \\
\hline Experiments & 0.720 & 0.864 & 0.589 & 1.309 & 0.524 & 0.196 & 0.720 \\
\hline Total Operation & 3.600 & 2.004 & 1.244 & 4.844 & 1.265 & 0.415 & 1.680 \\
\hline Decommissioning & $10 \% 00$ & 10300 & 1., $016 \%$ & \%o89 & 0068 & 1000058 & 00100, \\
\hline Life-Cycle Total & $1.176 .46 \%$ & i. & $1.1 .12 \times 261=$ & $99927 \%$ & 2838 & $12.10 .760 \%$ & 3998 \\
\hline
\end{tabular}

Note: Shaded cells in spreadsheet indicate changes relative to Reference Case.

- Non:host expenditures are calculated by adjusting the labor included in "Total Non-Host Costs at Host Site" as follows:

(a) $5 / 6$ of the labor cost goes to pay for the scientists/engineers located at the host site; 1/6 is used to pay for support at the home institution.

(b) Only $69 \%$ of the labor payments made to the scientists/engineers at the host site are actually spent at the site; the remaining $31 \%$ is for taxes, pension contributions, etc.

** Aggregated total expenditures in U.S. economy due to ITER. 


\title{
DISTRIBUTION FOR ANL/DIS-2
}

\section{Internal}

ANL Technical Publications Services

J. Peerenboom (288)

L. Welko (5)

\author{
M. Clemmons
}

\section{External}

U.S. Department of Energy Office of Scientific and Technical Information (12) Manager, U.S. Department of Energy Chicago Field Office

ANL-E Libraries

ANL-W Libraries 